\title{
Integrating nitrogen fluxes at the European scale
}

Book or Report Section

Leip, A., Achermann, B., Billen, G., Bleeker, A., Bouwman, A., de Vries, W., Dragosits, U., Doring, U., Fernall, D., Geupel, M., Herolstab, j., Johnes, P., Le Gall, A. C., Monni, S., Neveceral, R., Orlandini, L., Prud'homme, M., Reuter, H., Simpson, D., Seufert, G., Spranger, T., Sutton, M., van Aardenne, J., Voss, M. and Winiwarter, W. (2011) Integrating nitrogen fluxes at the European scale. In: Sutton, M., Howard, C., Erisman, J. W., Billen, G., Bleeker, A., Greenfelt, P., van Grinsven, H. and Grizzette, B. (eds.) The European Nitrogen Assessment. Cambridge University Press, Cambridge, pp. 345-376. ISBN 9781107006126 Available at https://centaur.reading.ac.uk/28386/

It is advisable to refer to the publisher's version if you intend to cite from the work. See Guidance on citing.

Publisher: Cambridge University Press

All outputs in CentAUR are protected by Intellectual Property Rights law, including copyright law. Copyright and IPR is retained by the creators or other copyright holders. Terms and conditions for use of this material are defined in 
the End User Agreement.

www.reading.ac.uk/centaur

\section{CentAUR}

Central Archive at the University of Reading

Reading's research outputs online 


\title{
Integrating nitrogen fluxes at the European scale
}

\author{
Lead author: Adrian Leip \\ Contributing authors: Beat Achermann, Gilles Billen, Albert Bleeker, Alexander F. Bouwman, \\ Wim de Vries, Ulli Dragosits, Ulrike Döring, Dave Fernall, Markus Geupel, Jürg Herolstab, \\ Penny Johnes, Anne Christine Le Gall, Suvi Monni, Rostislav Nevečeřal, Lorenzo \\ Orlandini, Michel Prud'homme, Hannes I. Reuter, David Simpson, Guenther Seufert, Till \\ Spranger, Mark A. Sutton, John van Aardenne, Maren Voß and Wilfried Winiwarter
}

\section{Executive summary}

\section{Nature of the problem}

- Environmental problems related to nitrogen concern all economic sectors and impact all media: atmosphere, pedosphere, hydrosphere and anthroposphere.

- Therefore, the integration of fluxes allows an overall coverage of problems related to reactive nitrogen $\left(\mathrm{N}_{\mathrm{r}}\right)$ in the environment, which is not accessible from sectoral approaches or by focusing on specific media.

\section{Approaches}

- This chapter presents a set of high resolution maps showing key elements of the $\mathrm{N}$ flux budget across Europe, including $\mathrm{N}_{2}$ and $\mathrm{N}_{\mathrm{r}}$ fluxes.

- Comparative nitrogen budgets are also presented for a range of European countries, highlighting the most efficient strategies for mitigating $\mathrm{N}_{\mathrm{r}}$ problems at a national scale. A new European Nitrogen Budget (EU-27) is presented on the basis of state-of-the-art Europe-wide models and databases focusing on different segments of Europe's society.

\section{Key findings}

- From c. $18 \mathrm{Tg} \mathrm{N}_{\mathrm{r}} \mathrm{yr}^{-1}$ input to agriculture in the EU-27, only about $7 \mathrm{Tg} \mathrm{N}_{\mathrm{r}} \mathrm{yr}^{-1}$ find their way to the consumer or are further processed by industry.

- Some 3.7 $\mathrm{Tg} \mathrm{N}_{\mathrm{r}} \mathrm{yr}^{-1}$ is released by the burning of fossil fuels in the EU-27, whereby the contribution of the industry and energy sectors is equal to that of the transport sector. More than $8 \mathrm{Tg} \mathrm{N}_{\mathrm{r}} \mathrm{yr}^{-1}$ are disposed of to the hydrosphere, while the EU-27 is a net exporter of reactive nitrogen through atmospheric transport of c. $2.3 \mathrm{Tg} \mathrm{N}_{\mathrm{r}} \mathrm{yr}^{-1}$.

- The largest single sink for $\mathrm{N}_{\mathrm{r}}$ appears to be denitrification to $\mathrm{N}_{2}$ in European coastal shelf regions (potentially as large as the input of mineral fertilizer, about $11 \mathrm{Tg} \mathrm{N} \mathrm{yr}^{-1}$ for the EU-27); however, this sink is also the most uncertain, because of the uncertainty of $\mathrm{N}_{\mathrm{r}}$ import from the open ocean.

\section{Major uncertainties}

- National nitrogen budgets are difficult to compile using a large range of data sources and are currently available only for a limited number of countries.

- Modelling approaches have been used to fill in the data gaps in some of these budgets, but it became obvious during this study that further research is needed in order to collect necessary data and make national nitrogen budgets inter-comparable across Europe.

- In some countries, due to inconsistent or contradictory information coming from different data sources, closure of the nitrogen budget was not possible.

\section{Recommendations}

- The large variety of problems associated with the excess of $\mathrm{N}_{\mathrm{r}}$ in the European environment, including adverse impacts, requires an integrated nitrogen management approach that would allow for creation and closure of $\mathrm{N}$ budgets within European environments.

- Development of nitrogen budgets nationwide, their assessment and management could become an effective tool to prioritize measures and prevent unwanted side effects.

The European Nitrogen Assessment, ed. Mark A. Sutton, Clare M. Howard, Jan Willem Erisman, Gilles Billen, Albert Bleeker, Peringe Grennfelt, Hans van Grinsven and Bruna Grizzetti. Published by Cambridge University Press. ( Cambridge University Press 2011, with sections $\odot$ authors/European Union. 


\subsection{Introduction}

The concept of the nitrogen cascade was introduced to describe the ' $[\ldots]$ multiple linkages among the ecological and human effects of reactive nitrogen molecules as they move from one environmental system to another' (Galloway et al., 2003). The quantification of the nitrogen cascade requires accurate estimation of the fluxes across the sectoral and media boundaries for a large geographic entity, from regional to national, continental and global scale. Such a complete nitrogen (N)-budget was first presented for Europe by van Egmond et al. (2002). In this chapter, an update is given of the information on complete $\mathrm{N}$-budgets, including all major $\mathrm{N}_{2}$ and reactive nitrogen $\left(\mathrm{N}_{\mathrm{r}}\right)$ fluxes, both at country and at continental level.

The European Nitrogen Assessment (ENA) provides an overview of the processes and pathways associated with the cascade of $\mathrm{N}_{\mathrm{r}}$ through the environment, and also the order of magnitude of the associated problems, based on recent scientific literature and latest available model results. Each of the chapters focuses on one specific sector (for example de Vries et al., Chapter 15, on the $\mathrm{N}$ fluxes from agriculture and natural ecosystems and Svirejeva-Hopkins et al., Chapter 12, on the effect of urbanization), on one specific medium (such as for example Simpson et al., Chapter 14, on the transport of $\mathrm{N}_{\mathrm{r}}$ in the atmosphere and Billen et al., Chapter 13, looking at nitrogen from the perspective of watersheds or on one specific aspect in the nitrogen cascade (for example the transformation processes in soils in Butterbach-Bahl et al., Chapter 6, or chemical reactions occurring in the atmosphere in Hertel et al., Chapter 9).

The inter-connections between these specific assessments are manifold and reflect the interactions that nitrogen undergoes in the environment across the borders of scales, sectors and media. The present chapter stands at the interface between the sections describing nitrogen issues and those explaining nitrogen problems and suggesting nitrogen solutions.

Two objectives are identified.

(i) To give an overview of the most important $\mathrm{N}$-fluxes in Europe in a gridded representation, i.e. compiling a number of 'key maps' that help the understanding of regional differences of the main $\mathrm{N}$-indicators.

(ii) To show aggregated fluxes of nitrogen across media and sectors, i.e. integrated national N-budgets for those countries where they have already been established and a new 'European Nitrogen Budget' based on the evidence compiled and the filling in of gaps according to the latest scientific knowledge.

The second goal, in particular, is a challenging one, as most research is done in individual disciplines and only a few 'integrated' models exist today that are able to give a comprehensive overview of the nitrogen budget at a national scale. However, while some decades ago the focus of research was on individual fluxes (e.g. nitrate concentrations in rivers), and specific tools (e.g. models of $\mathrm{N}_{2} \mathrm{O}$ fluxes from agricultural soils), in recent years progress has been made in developing tools and databases which cross sector- and media-boundaries and are able to consider effects such as 'pollution swapping' and to evaluate tradeoffs. The need to mitigate environmental problems related to nitrogen in an integrated way has led to the development of 'national nitrogen budgets' aimed at helping to find the most efficient and cost-effective solutions to abate these problems.

Still, the establishment of a nitrogen budget requires (i) the co-operation of experts from different disciplines and/or (ii) the integration of various dedicated models. Nitrogen budgeting at the national scale often relies on the first solution, as the density of experimental observations at the national scale might be sufficient to come up with good estimates of nitrogen fluxes between sub-systems, and model-results can (if needed) be used to fill gaps. Such national or (in the case of Europe) supra-national nitrogen budgets are increasingly recognized to be a very useful tool for visualizing the complexity of nitrogen issues, also in relation to society as a whole. These national nitrogen budgets help to support prioritization of policies and provide a first assessment of the impact a policy might have at various points in the nitrogen cascade.

In order to understand the fluxes that are included in the establishment of European and national nitrogen budgets, we employ a number of models covering partial aspects of an overall budget. Each model has its strengths and weaknesses. Therefore combining the best features of these models provides a means for the construction of a cross-sector, crossmedia European Nitrogen Budget. The following sections give an overview of the main data sources and models used for the key-maps presented in Section 16.3 as well as for the European Nitrogen Budget (for the EU-27) presented in Section 16.4, where we also present national N-budgets developed by country experts on the basis of national data sources.

\subsection{Data sources}

For the assessment of key nitrogen fluxes at the European scale and the development of a European Nitrogen Budget, one cannot rely on statistical or observational data as they do not exist for most of the fluxes that need to be considered. Observational data are scarce and unevenly distributed over the European area, so that a statistical up-scaling is often not possible. Instead, models are needed that extrapolate nitrogen (and other) fluxes at large scales on the basis of existing environmental or statistical information. Here, we make use of the results of such models. The models were selected on the basis of the following criteria: (i) applicability at the European scale; (ii) a high spatial data resolution, the European scale notwithstanding; and (iii) a focus in the parameterization of nitrogen fluxes in the compartments considered (see also de Vries et al., 2011, Chapter 15 this volume).

The CAPRI-DNDC-based Integrated Database for European Agriculture (IDEAg) gives currently the most complete information on the flow of nitrogen into and through the agricultural sector in Europe, calculating also reactive nitrogen and greenhouse gas fluxes (Leip et al., 2008; Leip et al., 2010a). The Indicator Database for European Agriculture builds mainly 
on the results from the economic model for agriculture CAPRI (Britz and Witzke, 2008) and the biophysical model for soil nutrient turnover DNDC (Li, 2000) through a meta-modelling approach (Britz and Leip, 2009). IDEAg covers all nitrogen fluxes related to agricultural activities in Europe. It has recently been extended to cover also $\mathrm{N}_{\mathrm{r}}$ emissions from sewerage systems in accordance with the methodology developed for the IMAGE model (Bouwman et al., 2006).

The INTEGRATOR model is an integrated model specifically designed to help developing integrated policies. It has been developed to assess responses of nitrogen and greenhouse gas (GHG) emissions to European-scale changes in land use, land management and climate. INTEGRATOR links modules calculating $\mathrm{N}$ and GHG emissions from housing and manure storage systems, agricultural and non-agricultural soils and surface waters, while accounting for the interaction between different sources through an emission-deposition model for $\mathrm{NH}_{3}$ and $\mathrm{NO}_{\mathrm{x}}$. It uses relatively simple and transparent model calculations based on the use and adaptation of available model approaches, including empirical model approaches and statistical relations between model outputs and environmental variables. The model focuses on the derivation of high resolution spatially explicit data (De Vries et al., 2009).

The Emission Database for Global Atmospheric Research (EDGAR) calculates emissions of air pollutants and greenhouse gases on a grid for use in atmospheric circulation models covering all relevant anthropogenic emission sectors (Olivier et al., 2005; Van Aardenne et al., 2001). EDGAR was used as the standard database for deriving emission estimates as it provides a consistent emission calculation of emissions for the whole territory considered and a sophisticated downscaling procedure to map emissions at high spatial resolution, including ship and aviation emissions and detailed sub-sector disaggregation. Two datasets have been applied in this report. $\mathrm{N}_{2} \mathrm{O}$ emissions have been taken from EDGARv4.0 (JRC/PBL, 2009) and the $\mathrm{NO}_{\mathrm{x}}$ and $\mathrm{NH}_{3}$ emissions are taken from the EDGAR-CIRCE dataset (Van Aardenne et al., 2009).

The Unified EMEP model is used to estimate atmospheric transport and deposition as calculated by the Europeanscale EMEP MSC-W Chemical transport model (European Monitoring and Evaluation Programme, Meteorological Synthesizing Centre - West). The EMEP models have been instrumental to the development of air quality policies in Europe since the late seventies, mainly through their support to the strategy work under the Convention on Long-range Transboundary Air Pollution, and became the reference atmospheric dispersion model for use in the Integrated Assessment Models supporting the development of air quality polices under the EU Commission. The Unified EMEP model is designed to calculate air concentrations and deposition fields for major acidifying and eutrophying pollutants, photo-oxidants and particulate matter (Simpson et al., 2006).

Additional information on these models can be found in the supplementary material (see supplementary material Chapter 15 and 16) including also a comparison of total atmospheric $\mathrm{N}_{\mathrm{r}}$ emissions fluxes by various data sets. Details on the data sets used by these models to estimate $\mathrm{N}_{\mathrm{r}}$ fluxes is given in
Table 16.1 Overview table of main models used in this chapter to generate the key maps and the European Nitrogen Budget (ENB)

$\begin{array}{ll}\text { Model } & \text { Nitrogen fluxes estimated for the ENB } \\ \text { IDEAg } & \text { emissions and nitrogen leaching and run-off } \\ & \text { from agriculture } \\ \text { exchange of nitrogen between the soil and the } & \text { livestock sectors } \\ \text { application of mineral fertilizer to agricultural } & \text { soils } \\ \text { feed and food trade } & \text { land productivity, consumption of nitrogen } \\ \text { nitrogen input to and emissions from sewage } & \text { treatment systems } \\ \text { emissions and nitrogen leaching from forests } \\ \text { and rough grazing } \\ \text { emissions from stationary combustion (energy } \\ \text { sector, industry, residential sector) and } \\ \text { industrial processes } \\ \text { emissions from transport } \\ \text { nitrogen input to solid waste management } \\ \text { emissions from solid waste management } \\ \text { atmospheric deposition }\end{array}$

de Vries et al. (2011, Chapter 15, this volume). A summary of the models used and the main data obtained from each of these models is given in Table 16.1. Each model focuses on different sectors and the models are thus complementary. Information for agriculture is available also from INTEGRATOR and EDGAR; because the IDEAg is the most complete source of information for agriculture the data in this chapter is taken from this model. This avoids most inconsistencies between the data presented. However, inconsistencies cannot be completely excluded and are mainly due to: (i) different atmospheric deposition data used in the IDEAg and INTEGRATOR model and the EMEP deposition data used in this chapter; and (ii) $\mathrm{N}_{\mathrm{r}}$ fluxes from coastal areas which are not included in any of the Europe-wide models.

Covering complex processes on a continental scale, the models are bound to rely on simplifying assumptions regarding input data sets, and the parameterization of the processes and the results presented here are consequently associated with large uncertainties. A proper assessment of these uncertainties, however, is very difficult as independent data that can be used to quantify the uncertainties are missing. An attempt to quantify the uncertainty of these (and other) models is currently being done within the European integrated project NitroEurope-IP (Sutton et al., 2007; NitroEurope, 2010). So far, the best approximation at an uncertainty assessment is done by comparing the in- and outputs of a wide range of models, as done by de Vries et al. (2011, Chapter 15 this volume).

\subsection{Key maps of nitrogen fluxes in Europe}

The purpose of this section is to present the spatial distribution of various types of key nitrogen fluxes over Europe that are 

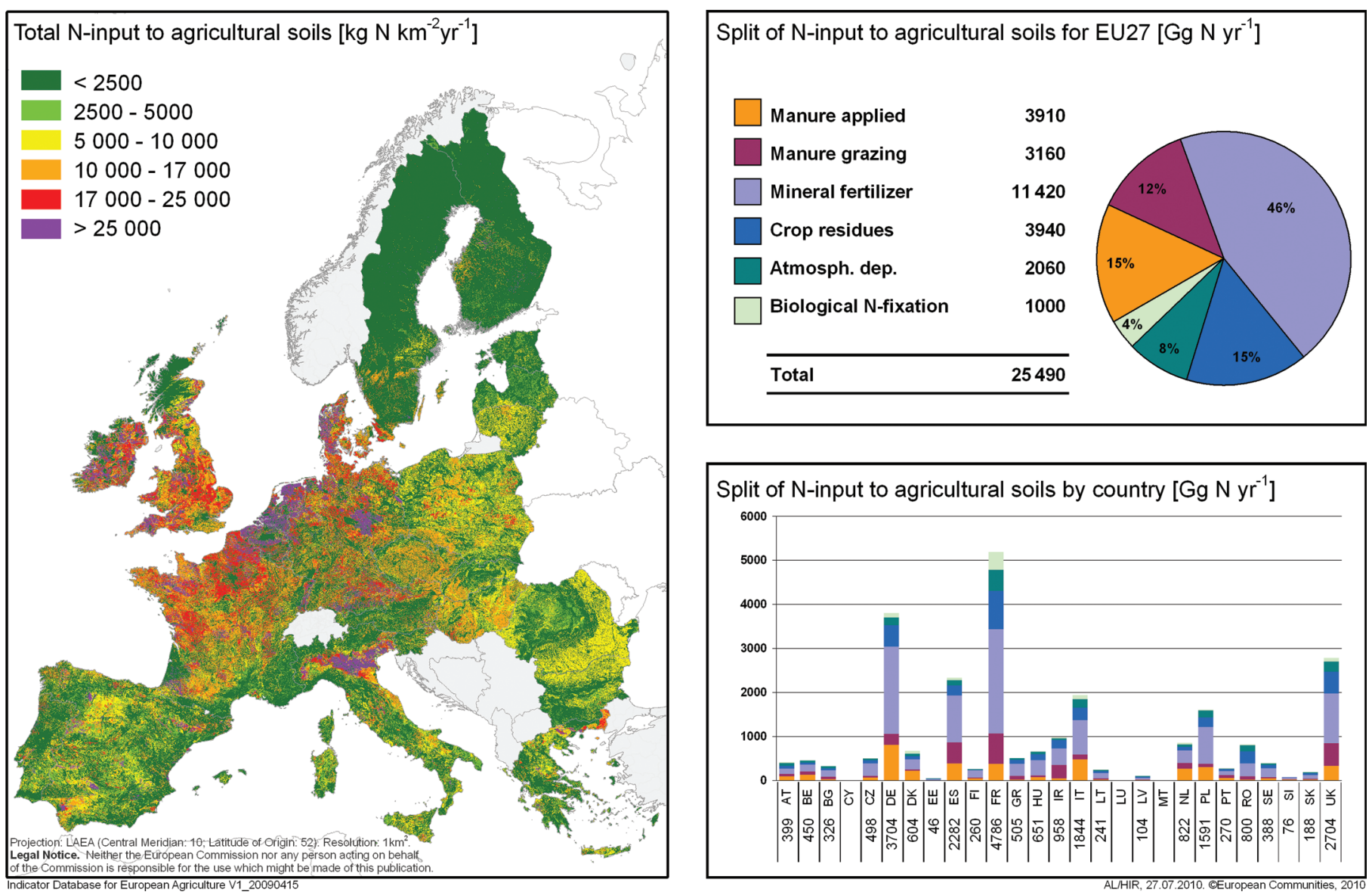

Figure 16.1 Nitrogen input to agricultural soils in EU27 for the year 2002. The map shows total reactive N input to agricultural soils (cropland and grassland) $\mathrm{yr}^{-1}$ for a grid at $1 \mathrm{~km} \times 1 \mathrm{~km}$, the values are in $\mathrm{kg} \mathrm{N}$ per total pixel area [ $\mathrm{kg} \mathrm{N} \mathrm{km}^{-2} \mathrm{yr}^{-1}$ total area]. The pie diagram at the right side gives the split of $\mathrm{N}$ input [Gg $\mathrm{N}$ rounded to $10 \mathrm{Gg} \mathrm{N} \mathrm{yr}^{-1}$ ] for EU27: mineral fertilizer, manure (intentionally applied manure and manure deposited by grazing animals), atmospheric deposition, biological nitrogen fixation and crop residues returned to the soil. The histogram shows the split of N input [Gg N year ${ }^{-1}$, rounded to $10 \mathrm{Gg} \mathrm{N}$ year $^{-1}$ ] by country. Basis: Indicator Database for European Agriculture (IDEAg) V1, 2009.

Method: Mineral fertilizer data are obtained from FAO at the national level and are distributed to crops and regions by the CAPRI model using information from IFA/FAO. Distribution to the grid is done on the basis of estimated crop N requirements using information of the potential and water-limited yield for the soil-climate conditions and N supply from biological fixation, atmospheric deposition, and manure nitrogen supply. Manure N supply is estimated from manure availability on the basis of a livestock density map, crop demand and typical share of nitrogen supply by organic nitrogen. The data are net of nitrogen losses occurring before the application of manure to the soil. All data are estimated in consistence with regional values using the highest posterior density approach (Heckelei et al., 2005). Nitrogen deposition data are from EMEP (2008). Biological nitrogen fixation is estimated as a crop-dependent fraction of above-ground nitrogen. Crop residues are estimated from crop-specific fraction and $\mathrm{N}$-content of crop residues. Details on the distribution algorithm can be found in Leip et al. (2008) and Britz and Leip (2009).

responsible for environmental problems. Maps are derived on the basis of fine scale resolution data $(1 \mathrm{~km} \times 1 \mathrm{~km})$. The only way to obtain data on such a high resolution was to apply models and combine their results with measurements where available. Most of the models and data sources used have already been presented and explained in detail in earlier chapters. All together, 11 such key maps are selected. They can be grouped into three categories.

(i) Drivers for and pressures of nitrogen in terrestrial ecosystems, including both agricultural and nonagricultural systems. Here the total load of nitrogen on agricultural soils (Figure 16.1) and the gross soil nitrogen budget for agricultural (Figure 16.2) and non-agricultural soils (Figure 16.3) can be regarded as key-indicators. Input of nitrogen through atmospheric deposition (Figure 16.4) is a major pressure on (semi-) natural ecosystems. (ii) Emissions of reactive nitrogen to the atmosphere and to the hydrosphere. This is a very important pressure for environmental problems related to nitrogen. We show separate maps on $\mathrm{NH}_{3}$ (Figure 16.5), $\mathrm{NO}_{\mathrm{x}}$ (Figure 16.6), and $\mathrm{N}_{2} \mathrm{O}$ (Figure 16.7) emissions across Europe. Each of these compounds is dominated by different source categories (energy/transport for $\mathrm{NO}_{\mathrm{x}}$, the livestock sector for $\mathrm{NH}_{3}$, soils for $\mathrm{N}_{2} \mathrm{O}$ ), so that the distinction between these compounds gives also an idea of the spatial distribution of the main driving forces for reactive nitrogen generation. Emissions of nitrogen towards aquatic systems are presented in Figure 16.8.

(iii) Secondary nitrogen indicators. Three indicators have been selected: the total productivity of agricultural land (Figure 16.9), and the total consumption of reactive nitrogen by humans (Figure 16.10) and by animals 

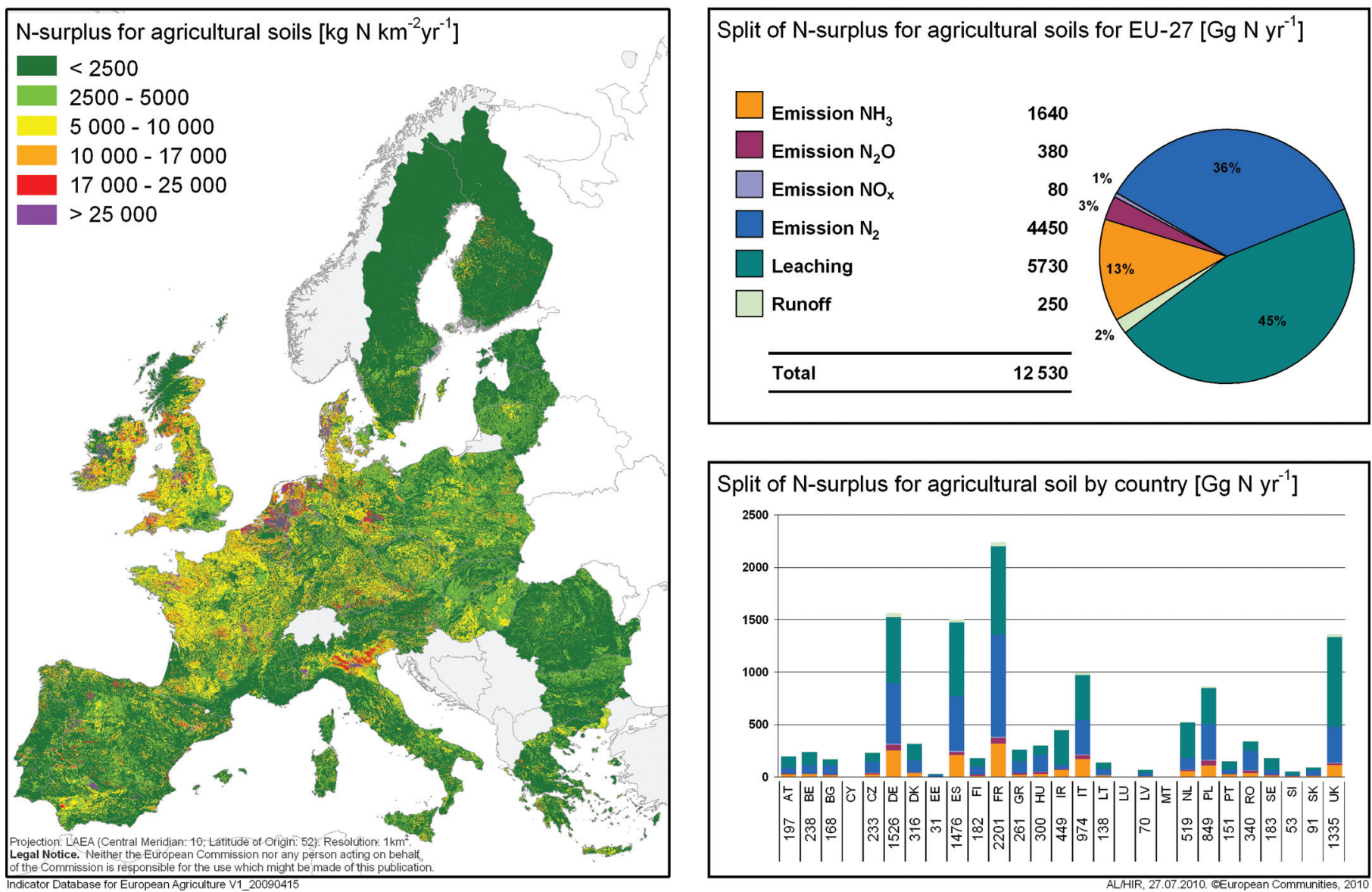

Figure 16.2 Soil system nitrogen surplus for agricultural soils in EU27 for the year 2002. The map shows reactive $\mathrm{N}$ surplus for a grid of $1 \mathrm{~km} \times 1 \mathrm{~km}$, the values are in $\mathrm{kg} \mathrm{N}$ per total pixel area [kg N km${ }^{-2} \mathrm{yr}^{-1}$ total area]. The pie diagram at the right side gives the split of surplus [Gg $N$ year ${ }^{-1}$, rounded to $10 \mathrm{Gg} \mathrm{N}$ year ${ }^{-1}$ ] for EU27 into the loss pathways: $\mathrm{NH}_{3}$ emissions from soils, $\mathrm{NO}_{x}$ emissions from soils $\mathrm{N}_{2} \mathrm{O}$ emissions from soils $\mathrm{N}_{2}$ emissions from soils, $\mathrm{N}$ leaching and runoff. The histogram shows the split of the $\mathrm{N}$ surplus [G $\mathrm{N} \mathrm{yr}^{-1}$ into different loss pathways by country. Basis: Indicator Database for European Agriculture V1, 2009.

Method: Nitrogen input to agricultural soils is estimated as given in Figure 16.1. Removal of nitrogen by crops and harvested or grazed grass is estimated from regional and national Eurostat statistics, downscaled to the grid on the basis of potential yield from (Genovese et al., 2007). Total N surplus at the grid scale is split into individual fluxes on the basis of the MITERRA approach ( $\mathrm{NH}_{3}$ emissions and run-off) as implemented in CAPRI (Britz and Witzke, 2008; Velthof et al., 2009) and the DNDC-CAPRI meta-model (Britz and Leip, 2009) for $\mathrm{N}_{2}, \mathrm{~N}_{2} \mathrm{O}, \mathrm{NO}_{x}$ and $\mathrm{N}$-leaching. The spatial distribution is done on the basis of the nitrogen input data. Changes in soil-nitrogen stocks are also estimated with the DNDC-CAPRI meta-model; according to the soil-system approach they are nitrogen output as thus not included in the split of the N-surplus. A closed nitrogen budget is obtained according to the method described by Leip et al. (2009a).

(Figure 16.11). While the first indicator shows the potential of the land to feed its population in Europe, the other two indicators give a good idea of the 'life style' of citizens. Taken together, these indicators give information on the sustainability of land use and are the basis for the watershed assessment discussed in Chapter 13 (Billen et al., 2011, Chapter 13 this volume).

\subsubsection{Drivers for and pressures of nitrogen in terrestrial ecosystems}

We select two indicators describing drivers for the environmental load of $\mathrm{N}_{\mathrm{r}}$ and two indicators for the pressure of $\mathrm{N}_{\mathrm{r}}$ on the environment. The total $\mathrm{N}_{\mathrm{r}}$ input to agricultural soils includes intentionally applied (organic or mineral) fertilizer and manure from grazing livestock as well as biological nitrogen-fixation and atmospheric deposition. Also crop residues returned to the soil are included in total $\mathrm{N}_{\mathrm{r}}$-inputs. Reactive nitrogen additions are required to fulfil the needs of plants without compromising the productivity of the soil. At the same time, however, excessive $\mathrm{N}_{\mathrm{r}}$ additions to agricultural soils lead to high pressures on the environment. Atmospheric deposition is the main source of $\mathrm{N}_{\mathrm{r}}$ for natural land and forests. Atmospheric deposition is fuelled mainly by the emissions of $\mathrm{NO}_{\mathrm{x}}$ from energy-related sources and $\mathrm{NH}_{3}$ lost from agriculture. There is limited capacity in natural ecosystem to absorb $\mathrm{N}_{\mathrm{r}}$. While initial $\mathrm{N}_{\mathrm{r}}$ additions to forests can lead to a stimulation of plant growth and the build-up of soil organic matter, additions to $\mathrm{N}_{\mathrm{r}}$-saturated systems have adverse effects on the system's functioning and most $\mathrm{N}_{\mathrm{r}}$ is leached (Aber, 1992; Butterbach Bahl et al., 2011, Chapter 6 this volume). We define nitrogen surplus as the difference between total $N_{r}$ inputs to a system and the useful outputs following the definition of the soil-system approach (de Vries et al., 2011, Chapter 15 this volume). Inputs are total $\mathrm{N}_{\mathrm{r}}$-input as defined above, while useful $\mathrm{N}_{\mathrm{r}}$ outputs are harvested crops, including crop residues, and grazed grass. Changes of 

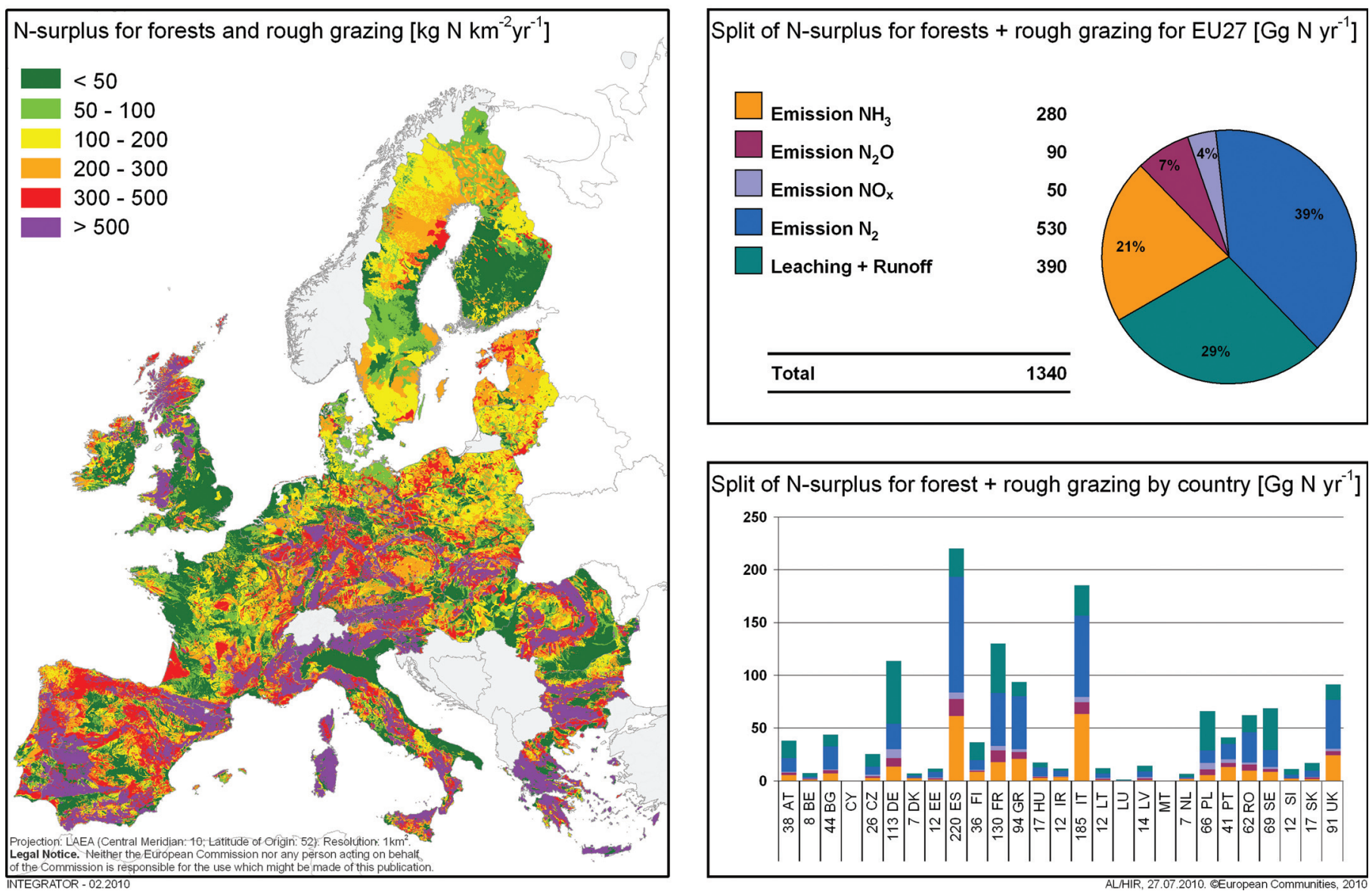

Figure 16.3 Soil system nitrogen surplus for forest soils (forests, scrublands, heather) in EU-27 for the year 2000. The map shows total reactive N surplus for a grid of $1 \mathrm{~km} \times 1 \mathrm{~km}$, the values are in $\mathrm{kg} \mathrm{N}$ per total pixel area [ $\mathrm{kg} \mathrm{N} \mathrm{km}^{-2} \mathrm{yr}^{-1}$ total area]. The pie diagram at the right side gives the split of surplus [Gg $N$ year ${ }^{-1}$ rounded to $10 \mathrm{Gg} \mathrm{N}$ year ${ }^{-1}$ f for EU27 into the loss pathways: emissions of $\mathrm{NH}_{3}, \mathrm{NO}_{x,} \mathrm{~N}_{2} \mathrm{O}$ and $\mathrm{N}_{2}$ and $\mathrm{N}$ leaching. The histogram shows the split of the $\mathrm{N}$ surplus $\left[\mathrm{Gg} \mathrm{N} \mathrm{r}^{-1}\right]$ into the loss pathways by country.

Basis: INTEGRATOR, 2009.

Method: Nitrogen surplus is estimated as the sum of gaseous nitrogen fluxes and nitrogen leaching. Nitrogen leaching is calculated in INTEGRATOR from the difference of total $\mathrm{N}$ input, via $\mathrm{N}$-deposition, biological nitrogen fixation and manure input where relevant, and the previously estimated nitrogen losses, via uptake by plant growth, $\mathrm{NH}_{3}$ losses, nitrification/denitrification gas losses, and net nitrogen immobilization. However, a minimum nitrogen leaching rate is postulated which is obtained from the water flux and a concentration of $0.02 \mathrm{mg} \mathrm{N} \mathrm{I}^{-1}$ (Stoddard, 1994). A check is made if the minimum N-leaching rate is achieved; otherwise this is obtained following pre-defined rules as described by de Vries et al. (2009).

soil $\mathrm{N}_{\mathrm{r}}$ stocks can occur in both a positive direction (filling-up the nitrogen pool) and negative direction (depletion of the $\mathrm{N}_{\mathrm{r}}$ pool). This is a transient process and can be reversed by changing farm management. According to the soil-system approach, changes in soil $\mathrm{N}_{\mathrm{r}}$ stocks adjust the accountable quantity of useful outputs. They have an equal impact on the $\mathrm{N}_{\mathrm{r}}$ surplus, however, not being part of a detailed split of the fate of $\mathrm{N}$-surplus (for a detailed discussion see Leip et al., 2010a). Nitrogen surplus on forest soils is defined by analogy: $\mathrm{N}_{\mathrm{r}}$-inputs are fertilizer application, atmospheric nitrogen deposition and biological nitrogen fixation, while $\mathrm{N}_{\mathrm{r}}$-outputs are nitrogen uptake by the plants and $\mathrm{N}_{\mathrm{r}}$ immobilization in the soil.

The input of $\mathrm{N}_{\mathrm{r}}$ to agricultural soils is dominated by the input of mineral fertilizer. Worldwide, the production of mineral fertilizer is the most important source (about 65\%) of the net increase of $\mathrm{N}_{\mathrm{r}}$ in the environment. While already for the global nitrogen cycle, human influence is larger than the natural dimensions of the nitrogen cycle (Galloway and Cowling, 2002).
In Europe the anthropogenic effect is even stronger. Application rates of mineral fertilizer and manure per hectare of utilized agricultural land is shown in Figure 15.7 (de Vries et al., 2011, Chapter 15 this volume). The pattern in the map in Figure 16.1, which shows the input of nitrogen for total surface area, is different from the maps presented in Chapter 15 as it gives an idea of the share of utilized agricultural area (UAA) across Europe. High shares of UAA up to more than $90 \%$ are found in intensive farming areas, such as the Po Valley in Italy, Central Spain, Western France and Romania (Leip et al., 2008). For other regions, such as Finland, the Baltic countries or mountainous regions, low shares of agricultural land of generally below $10 \%$ yield low $\mathrm{N}$ input data even though the application rates per hectare of cultivated land can reach high values, as is the case in certain Finnish regions. The range of manure input is very large, and covers values from $7 \mathrm{~kg} \mathrm{~N}$ per hectare UAA in Romania, to over $230 \mathrm{~kg} \mathrm{~N}$ (ha UAA) ${ }^{-1}$ in the Netherlands. For some countries, extensive rearing of ruminant animals predominates and 

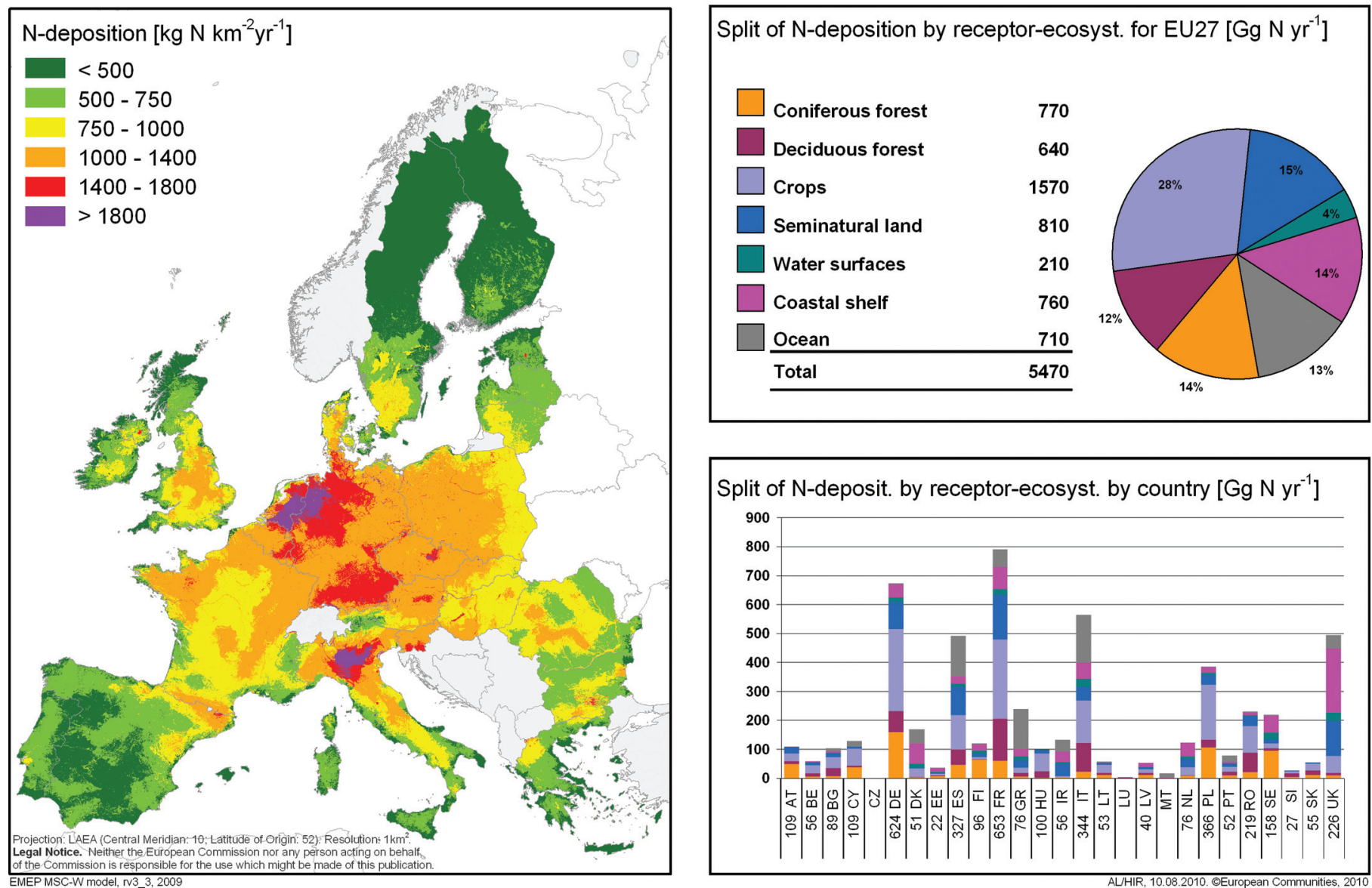

Figure 16.4 Atmospheric nitrogen deposition to in EU-27 for the year 2001. The map shows total reactive N deposition for a grid at $1 \mathrm{~km} \times 1 \mathrm{~km}$, the values are in $\mathrm{kg} \mathrm{N}$ per total pixel area [kg N km${ }^{-2} \mathrm{yr}^{-1}$ total area]. The pie diagram at the right side gives the split of $\mathrm{N}$ deposition to the different ecosystems [Gg $\mathrm{N}$ yr ${ }^{-1}$, rounded to $10 \mathrm{Gg} \mathrm{N} \mathrm{yr}^{-1}$ ] for EU27: coniferous forests, deciduous forests, cropland, seminatural land, and inland water surfaces as well as deposition to the coastal shelf and the deep ocean, which are not shown in the map. The histogram shows the split of $\mathrm{N}$ deposition [Gg N yr $\left.{ }^{-1}\right]$ by country. Basis: EMEP MSC-W model, rv3 3, 2009.

Method: Atmospheric N-deposition is calculated with the European-scale EMEP MSC-W Chemical transport model (European Monitoring and Evaluation Programme, Meteorological Synthesizing Centre - West). The EMEP model was designed primarily for the calculation of acidifying substances, ozone and particles over Europe (Simpson et al., 2003, see also www.emep.int; Simpson et al., 2011, Chapter 14). The chemical scheme uses about 140 reactions between 70 species (see Andersson-Sköld et al., 1999, and references therein), and makes use of the Equilibrium Simplified Aerosol Module (EQSAM) of Metzger et al. (2002) to describe equilibria between the inorganic aerosol components. Routine N-deposition fields from the EMEP model are available at ww.emep.int. The model uses a sub-grid calculation procedure (so-called 'mosaic' approach) to calculate deposition separately to 19 different land-cover categories, taking into account vegetation cover, phenology and surface-characteristics. Calculations of forest-specific deposition estimates, also exploring the role of forest soil-NO emissions from Kesik et al. (2005), were presented in Simpson et al. (2006).

the input of organic nitrogen occurs mainly through deposition of manure by grazing animals, e.g. $86 \%$ for Ireland and Greece according to CAPRI model estimates while this is only $20 \%$ and less in countries such as Poland, Slovenia and Denmark.

Atmospheric deposition and biological nitrogen fixation account together for only $12 \%$ of total $\mathrm{N}_{\mathrm{r}}$-input to agricultural soils. Generally, biological N-fixation decreases with increasing $\mathrm{N}_{\mathrm{r}}$ input due to increasing competitiveness of non-leguminous crops (Weigelt et al., 2009). However, as CAPRI estimates biological N-fixation to be a constant fraction of above-ground crop $\mathrm{N}_{\mathrm{r}}$ uptake (75\% for leguminous crops and $5 \%$ for grass), this effect is not considered and leads to a likely over-estimation of biological N-fixation in intensive regions such as North France and the Netherlands in comparison to extensive grassland areas such as in Poland and Romania.

The size of the $\mathrm{N}$ surplus in the agricultural sector (Figure 16.2) is a measure of the sustainability of the agricultural production process, since a surplus will eventually lead to shifting the environmental problems to other places outside of the agricultural sector or abroad, including a possible time lag. The contribution of nitrogen leaching to the fate of total N-surplus varies from $26 \%$ to $73 \%$. N-leaching is mainly a function of soil texture: heavy clay soils in Central and South Europe offer larger opportunities for denitrification than soils with high organic carbon content and sandy soils, which are less resistant to nitrogen losses to the water. Consequently, losses of $\mathrm{N}_{2}$ are negatively correlated to $\mathrm{N}$-leaching. Fluxes of $\mathrm{N}_{2}$ are very difficult to measure and therefore treated in most models as residual loss-pathway. In the IDEAg, $\mathrm{N}_{2}$ flux estimates are based on results of the DNDC model, but constrained by estimates of $\mathrm{NH}_{3}$ fluxes calculated as in the MITERRA model (Velthof et al., 2009, see also Chapter 15 this volume) and estimates of $\mathrm{N}$-leaching, $\mathrm{N}_{2} \mathrm{O}$ and $\mathrm{NO}_{\mathrm{x}}$ fluxes from the same DNDC metamodel. Nevertheless, the ratio of $\mathrm{N}_{2} / \mathrm{N}_{2} \mathrm{O}$ has a range between 

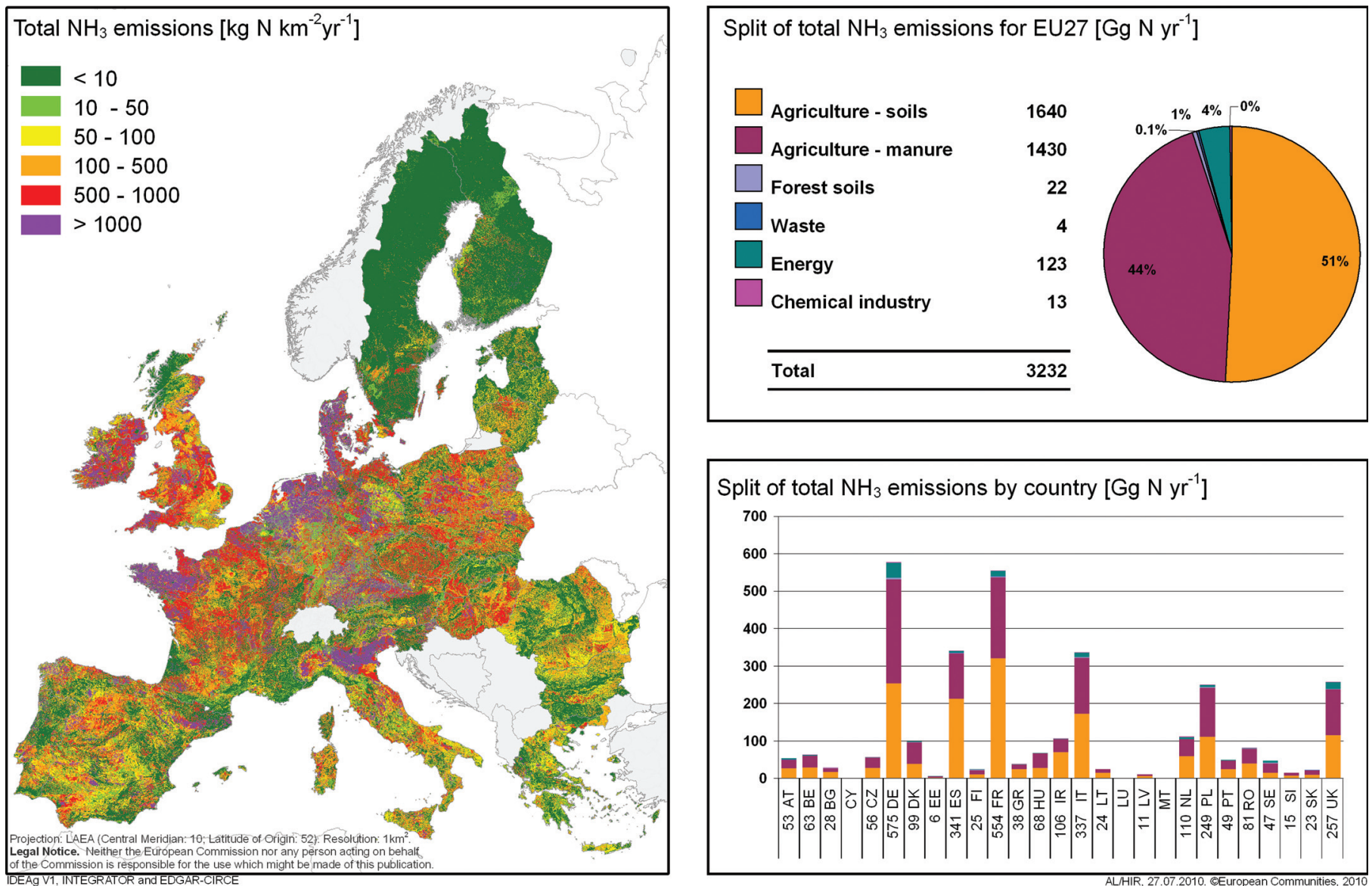

Figure 16.5 Total $\mathrm{NH}_{3}$ emissions in EU27 around the year 2000. The map shows the sum of $\mathrm{NH}_{3}$ emissions from terrestrial ecosystems, industry and waste management for a grid of $1 \mathrm{~km} \times 1 \mathrm{~km}$, the values are in $\mathrm{kg} \mathrm{N}$ per total pixel area [kg N km${ }^{-2} \mathrm{yr}^{-1}$ total area]. The pie diagram at the right side gives the split of total $\mathrm{NH}_{3}$ emissions [Gg N yr${ }^{-1}$, values for agriculture are rounded to $10 \mathrm{Gg} \mathrm{Nyr}^{-1}$ ] for EU27: agricultural soils including manure application, manure in housing systems and manure management systems excluding manure application, forest soils, emissions from waste, mainly composting of solid waste, energy, and the chemical industry. The histogram shows the split of $\mathrm{NH}_{3}$ emissions [Gg N yr$\left.{ }^{-1}\right]$ by country.

Basis: Agriculture: Indicator Database for European Agriculture V1, 2009; forest soils: INTEGRATOR, 2009; industrial processes and waste management: EDGARCIRCE (Van Aardenne et al., 2009).

Method: (i) Agriculture: emissions are estimated for manure and mineral fertilizer as described by Weiss (2010). Manure emissions are estimated for animal housing and manure management systems and following application on the basis of a mass-conserving approach. $\mathrm{NH}_{3}$ loss factors are taken from the GAINS model for liquid and solid manure and the emission is reduced according to an assumed implementation level for $\mathrm{NH}_{3}$ emission reduction measures using again default GAINS data (Klimont and Brink, 2004; Velthof et al., 2009). Emissions from mineral fertilizer nitrogen are calculated separately for urea and non-urea fertilizers. (ii) Forest soils: emissions are calculated using a constant natural background flux (after Simpson et al., 1999). (iii) Industrial processes: production data are from US geological survey statistics, UN industrial commodity statistics and data from SRI Consulting (2005). The emission factors are EMEP/EEA (2009). Emissions from industrial processes are allocated spatially based on point source maps for the most important source categories, and using population density for the remaining categories. (iv) Waste management: the amount of solid waste composted is estimated based on national reports to the UNFCCC (2008) and on data from European Compost Network (ECN, 2008). The emission factor is from EMEP/EEA (2009). Emissions from the waste sector are spatially distributed based on human population density.

5 and 30 (EU27-average 11.6) in-line with current understanding of the nitrogen cycle (Butterbach-Bahl et al., 2011, Chapter 6 this volume; Seitzinger et al., 2006). Fluxes of $\mathrm{NH}_{3}$ contribute between $6 \%$ and $17 \%$ to the total soil $\mathrm{N}$-surplus and depend on the type of manure or mineral fertilizer nitrogen applied, which is also country-specific. Countries with a high share of urea applied and/or a high livestock density have high losses of nitrogen to the atmosphere as $\mathrm{NH}_{3}$. Unlike agricultural soils, the most important nitrogen change for forest soils and soils under semi-natural land (see Figure 16.3) is $\mathrm{N}_{\mathrm{r}}$ accumulation in the soil (about 50\% for forest soils and 30\% for semi-natural land). The most important $\mathrm{N}_{\mathrm{r}}$ loss-pathways for forest soils are $\mathrm{N}_{2}$ and nitrogen leaching. As the map shows the $\mathrm{N}$-surplus calculated per square kilometre total area, it shows the spatial variation of two important factors: the $\mathrm{N}$ surplus per hectare of forest area, which is mainly affected by the water balance and soil properties, and the forest area itself, which is particularly high in mountains and in Northern Europe. Therefore, the spatial pattern of nitrogen surplus in forests mimics to a certain degree the topography of Europe, and is as such in contrast to agricultural $\mathrm{N}$ surplus.

$\mathrm{NH}_{3}$ emissions are not a significant loss pathway of $\mathrm{N}_{\mathrm{r}}$ from forest soils, as the input of mineral fertilizer and manure to forest soils is negligible in many countries, but it accounts for one third of the $\mathrm{N}_{\mathrm{r}}$ losses from rough grazing land. $\mathrm{NH}_{3}$ emissions include volatilization from urine, livestock manures (slurry and solid manure) and background emissions (see Simpson et al., (1999)). 

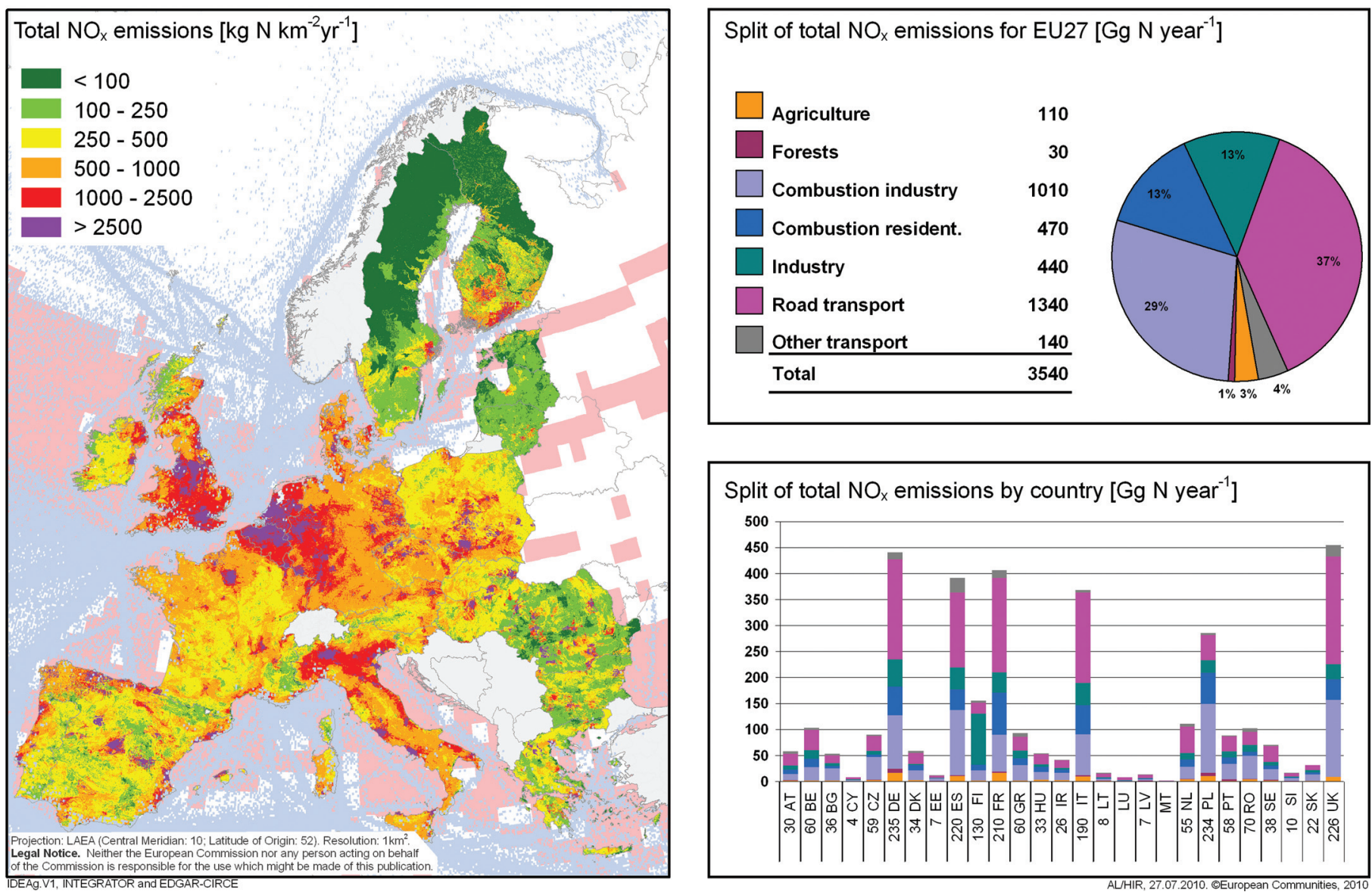

Figure 16.6 Total $\mathrm{NO}_{\mathrm{x}}$ emissions in EU-27 around the year 2000. The map shows the sum of $\mathrm{NO}_{\mathrm{x}}$ emissions from agriculture (both agricultural soils and manure in housing and manure management systems), forest soils, industrial processes, combustion (stationary and mobile) sources, and waste management (incineration) for a grid at of $1 \mathrm{~km} \times 1 \mathrm{~km}$. The values are in $\mathrm{kg} \mathrm{N}$ per total pixel area [ $\mathrm{kg} \mathrm{N} \mathrm{km}^{-2} \mathrm{yr}^{-1}$ total area]. The pie diagram on the right side gives the split of total $\mathrm{NO}_{x}$ emissions [Gg N yr-1, rounded to $10 \mathrm{Gg} \mathrm{N} \mathrm{yr}^{-1}$ ] for EU27: agriculture, forests, combustion in industry and residential combustion, industrial emissions, road and other transport. The histogram shows the split of $\mathrm{NO}_{x}$ emissions [ $\mathrm{Gg} \mathrm{N} \mathrm{yr}^{-1}$ ] by country. The map shows also the emissions from international aviation (red) and navigation (blue) which are not included in the national totals. Values are less than $40 \mathrm{~kg} \mathrm{~N} \mathrm{~km}^{-2} \mathrm{yr}^{-1}$.

Basis: Agriculture: Indicator Database for European Agriculture V1, 2009; forest soils: INTEGRATOR, 2009; industrial processes, combustion and fugitive emissions, and waste management: EDGAR-CIRCE (Van Aardenne et al., 2009).

Method: (i) Agriculture: emissions are calculated with the DNDC meta-model as described in Britz and Leip (2009). In the Indicator Database for European Agriculture, a correction of the $\mathrm{NO}_{x}$ fluxes is applied only if a closed $\mathrm{N}$-budget cannot be obtained through adjustment of $\mathrm{N}_{2}$ fluxes (considered as the weakest term in the DNDC meta-model) and N-leaching within the bounds set. Then, the loss terms $\mathrm{NO}_{x}, \mathrm{~N}_{2} \mathrm{O}, \mathrm{N}_{2}$, and $\mathrm{N}$-leaching are scaled to obtain a closed $\mathrm{N}$-budget. (ii) Forest soils: based on results with the model PnET-N-DNDC for European forest (Kesik et al., 2005) an $\mathrm{NO}_{x} / \mathrm{N}_{2} \mathrm{O}$ ratio of 1.25 is used. $\mathrm{N}_{2} \mathrm{O}$ emissions are estimated from a meta-model based on PnET-N-DNDC simulations (Kesik et al., 2005). (iii) Industrial processes: production data are from statistics of the US geological survey, UN industrial commodity statistics and data from SRI Consulting (SRIC, 2005). The emission factors are from EMEP/EEA (2009). emissions from industrial processes are allocated spatially based on point source maps for the most important source categories, and using population density for the remaining categories. (iv) Combustion and fugitive emissions: fuel consumption data by sector and fuel type (stationary) or transport mode and fuel type (mobile) is obtained from International Energy Agency (IEA) statistics (IEA/OECD, 2007). Production of crude oil is estimated based on IEA statistics (IEA/OECD, 2007), and venting/flaring is estimated based on data from the Carbon Dioxide Information Analysis Center (CDIAC, 2008), supplemented by reporting of the countries to the United Nations Framework Convention on Climate Change (UNFCCC). The emission factors are based on IPCC (2006)), EMEP/EEA (2009) and Amann et al. (2007). The emissions from stationary combustion are spatially distributed using point source maps for power plants, steel production plants, and oil refineries, and maps on urban and rural population density for the other sectors. (v) Combustion transport: emissions from transportation include road and rail transportation, domestic and international navigation, domestic and international aviation and other transportation. The fuel use by each transport mode and fuel type is from IEA statistics (IEA/OECD, 2007). The fuel use in international navigation is divided between sea and port activities of 15 ships types based on Dalsøren et al. (2009). Fuel consumption in aviation is divided between landing and take-off; climbing and descent; cruise; and super-sonic based on gridded data from the AERO2K project (Eyers et al., 2004). A detailed split of the fuel used in road transportation is used in the EDGAR database considering heavy and light duty vehicles, passenger cars, buses, mopeds, and motorcycles by applying country-specific fleet distribution calculated based on registration, number of vehicles, and driven vehicle kilometres from International Road Federation (IRF, 2007). The impact of emission control measures is calculated based on European emissions standards (EURO 0 - EURO 4) and other regional standards, with data from CONCAWE (2001) and EMEP/EEA (2009). The emission factors are based on EMEP/EEA (2009), EIPPC BREF, IPCC (2006) and scientific literature. Emissions from aviation are spatially allocated based on AERO2K project, and presented separately for domestic and international aviation. Emissions from road transportation are spatially allocated using road density map, weighted with population in the case of passenger cars Emissions from international navigation are spatially allocated using a ship traffic density map of Wang et al. (2007). Other transport emissions are gridded using population density. (vi) Waste management: the amount of solid waste incinerated without energy recovery is estimated based on the reporting of the countries to the UNFCCC. The emission factors for solid waste are from EMEP/EEA (2009). Emissions from the waste sector are spatially distributed based on human population density. 


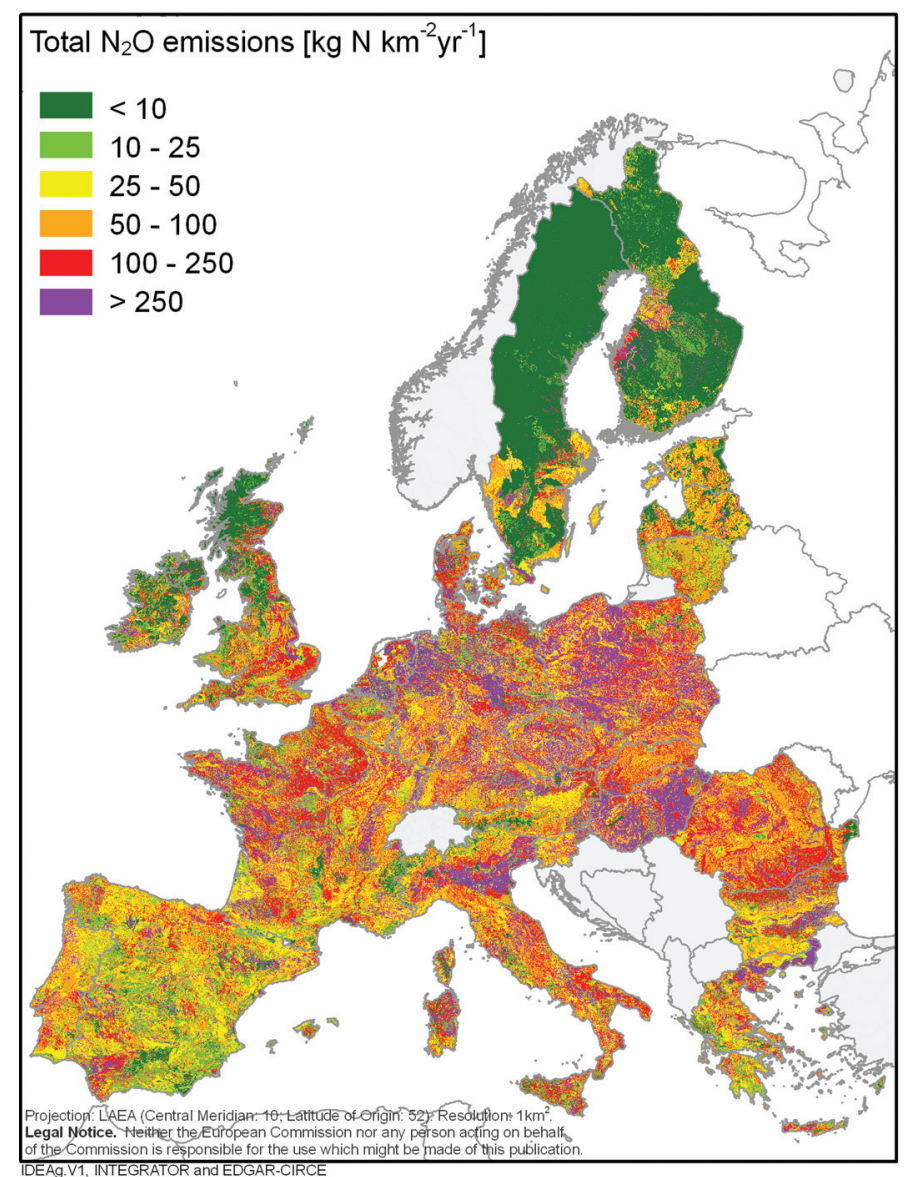

Split of total $\mathrm{N}_{2} \mathrm{O}$ emissions for EU27 [Gg N yr $\left.{ }^{-1}\right]$

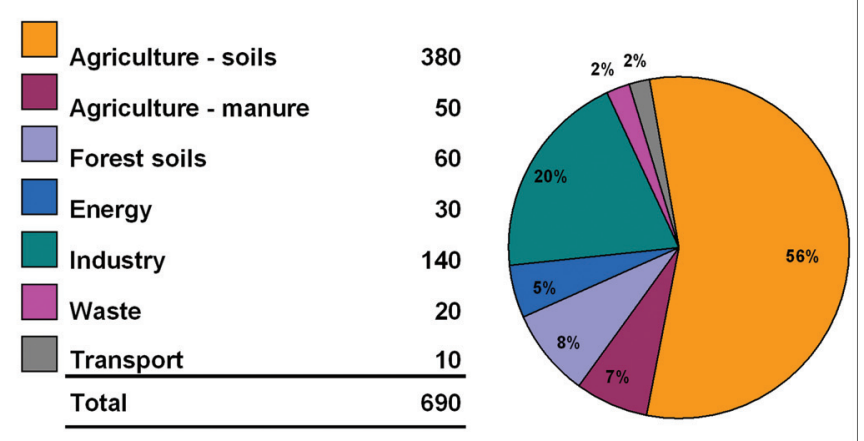

Split of total $\mathrm{N}_{2} \mathrm{O}$ emissions by country $\left[\mathrm{Gg} \mathrm{N} \mathrm{yr}{ }^{-1}\right]$

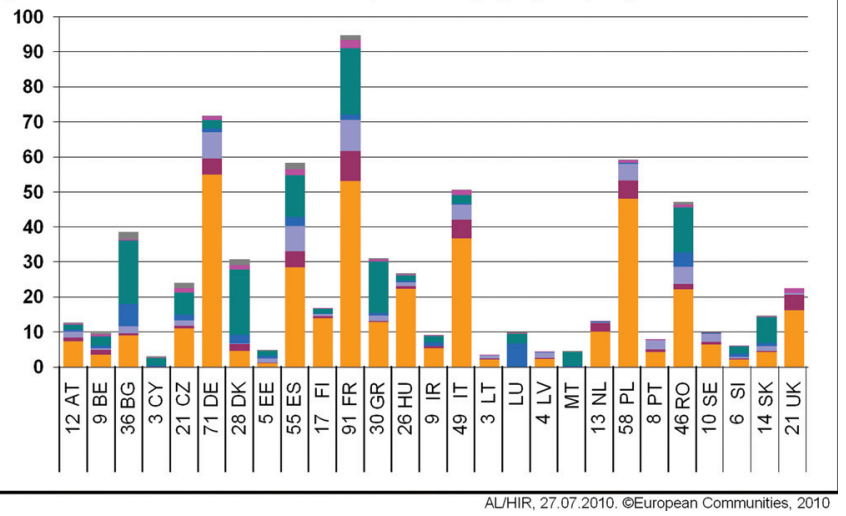

Figure 16.7 Total $\mathrm{N}_{2} \mathrm{O}$ emissions in EU-27 around the year 2000. The map shows total $\mathrm{N}_{2} \mathrm{O}$ emissions from terrestrial ecosystems, industry, energy and waste for a grid of $1 \mathrm{~km} \times 1 \mathrm{~km}$. The values are in $\mathrm{kg} \mathrm{N}$ per total pixel area [ $\mathrm{kg} \mathrm{N} \mathrm{km}^{-2}$ total area]. The pie diagram at the right side gives the split of total $\mathrm{N}_{2} \mathrm{O}$ emissions [Gg N year ${ }^{-1}$, rounded to $10 \mathrm{Gg} \mathrm{N}$ year $^{-1}$ ] for EU-27: agricultural soils, manure management excluding manure spreading on soils, forest soils, energy (large scale and domestic), industry (mainly chemical industry), waste (wastewater treatment and other waste) and transport (road and non-road). The histogram shows the split of $\mathrm{N}_{2} \mathrm{O}$ emissions [Gg N yr$\left.{ }^{-1}\right]$ by country.

Basis: Agriculture: Indicator Database for European Agriculture V1, 2009; forest soils: INTEGRATOR, 2009; industrial processes, combustion, and solid waste management: EDGARv4 (JRC/PBL, 2009); waste water systems: Indicator database for European Agriculture V1, 2009.

Method: (i) Agriculture: emissions are calculated with the DNDC meta-model as described in Britz and Leip (2009). In the Indicator Database for European Agriculture, $\mathrm{N}_{2} \mathrm{O}$ fluxes are corrected to obtain a closed $\mathrm{N}$-budget only in case the correction of $\mathrm{N}_{2}$ fluxes (considered as the weakest term in the DNDC metamodel) and $\mathrm{N}$-leaching alone is not possible within the bounds set. In this case, the loss terms $\mathrm{NO}_{x^{\prime}} \mathrm{N}_{2} \mathrm{O}$, $\mathrm{N}_{2}$, and $\mathrm{N}$-leaching are scaled to obtain a closed $\mathrm{N}$-budget. (ii) Forest soils: emissions are estimated from a meta-model based on simulation results for European forest soils with the model PnET-N-DNDC (Kesik et al., 2005). (iii) Industrial processes: production data are from statistics of the US geological survey, UN industrial commodity statistics and data from SRI Consulting (SRIC, 2005). Abatement of $\mathrm{N}_{2} \mathrm{O}$ emissions from nitric acid and adipic acid emissions is included based on the reporting of countries to the UNFCCC. The emission factors are from IPCC (2006). Emissions from industrial processes are allocated spatially based on point source maps for the most important source categories, and using population density for the remaining categories. (iv) Combustion and fugitive emissions: fuel consumption data by sector and fuel type (stationary) or transport mode and fuel type (mobile) is obtained from International Energy Agency (IEA) statistics (IEA/OECD, 2007). The emission factors are based on IPCC (2006) and other sources. The emissions from stationary combustion are spatially distributed using point source maps for power plants. (v) Combustion transport: emissions from transportation include road and rail transportation, domestic and international navigation, domestic and international aviation and other transportation. The fuel use by each transport mode and fuel type is from IEA statistics (IEA/OECD, 2007). The fuel use in international navigation is divided between sea and port activities of 15 ships types based on Dalsøren et al. (2009). Fuel consumption in aviation is divided between landing and take-off; climbing and descent; cruise; and super-sonic based on gridded data from the AERO2K project (Eyers et al., 2004). A detailed split of the fuel used in road transportation is used in the EDGAR database considering heavy and light duty vehicles, passenger cars, buses, mopeds, and motorcycles by applying country-specific fleet distribution calculated based on registration, number of vehicles, and driven vehicle kilometres from International Road Federation (IRF, 2007). The impact of emission control measures is calculated based on European emissions standards (EURO 0 - EURO 4) and other regional standards, with data from CONCAWE (2001) and EMEP/EEA (2009). The emission factors are based on IPCC (2006). Emissions from aviation are spatially allocated based on AERO2K project, and presented separately for domestic and international aviation. Emissions from road transportation are spatially allocated using road density map, weighted with population in the case of passenger cars. Emissions from international navigation are spatially allocated using a ship traffic density map of Wang et al. (2007). Other transport emissions are gridded using population density. (vi) Solid waste management: the amount of solid waste composted and incinerated is estimated based on the reporting of the countries to the UNFCCC. Composting data are complemented with information from European Compost Network (ECN, 2008). The emission factors for solid waste are from IPCC (2006). Emissions from the waste sector are spatially distributed based on human population density. (vii) Waste-water systems: emissions from nitrogen in effluents $\left(0.005 \mathrm{~kg} \mathrm{~N}_{2} \mathrm{O}-\mathrm{N} \mathrm{kg}^{-1} \mathrm{~N}\right)$ as well as emissions from advanced sewage treatments systems $\left(3.2 \mathrm{~g} \mathrm{~N}_{2} \mathrm{O}\right.$ person $\left.{ }^{-1} \mathrm{yr}^{-1}\right)$ are from IPCC (2006). 

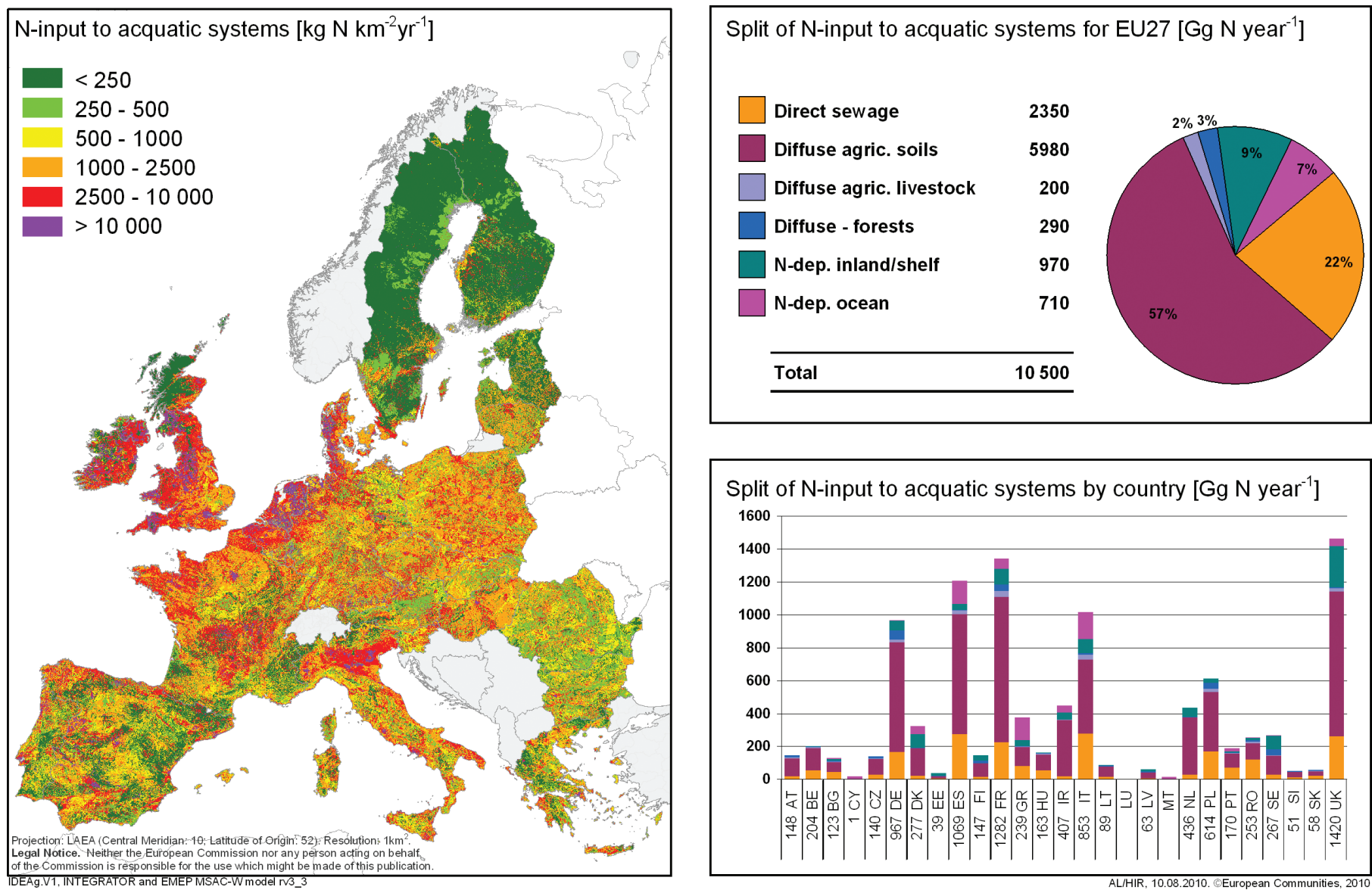

Figure 16.8 Total reactive N input to the hydrosphere (rivers and groundwater) in EU-27 for the year 2002. The map shows total $N_{r}$ point sources from sewerage systems and diffuse sources from agriculture and forest soils and atmospheric $N_{r}$ deposition to inland water surfaces for a grid at of $1 \mathrm{~km} \times 1 \mathrm{~km}$. The values are in $\mathrm{kg} \mathrm{N}$ per total pixel area [ $\mathrm{kg} \mathrm{N} \mathrm{km}^{-2} \mathrm{yr}^{-1}$ total area]. The pie diagram at the right side gives the split of N input to the hydrosphere [Gg N year-1, rounded to $10 \mathrm{Gg}$ $\mathrm{N}_{\text {year }}{ }^{-1}$ f for EU27: point sources (sewage systems) and diffuse sources (agriculture leaching, run-off, and forest soils). The histogram shows the split of $\mathrm{N}_{\mathrm{r}}$ input to the hydrosphere [Gg N year ${ }^{-1}$ by country.

Basis: Sewage systems and agriculture: Indicator Database for European Agriculture V1, 2009; forest soils: INTEGRATOR, 2009.

Method: (i) Sewage systems: nitrogen in agricultural products is estimated with CAPRI, N from fish is obtained from Eurostat fish statistics and a mean N-content of 2.6\%. Non-consumed proteins (waste) are assumed to be 30\%. N retention in sewage systems is calculated from the percentage of people connected to sewage systems (for rural and urban population) with mechanic, biological or advance treatment and corresponding retention efficiencies is obtained from Van Drecht et al. (2009). According to IPCC (2006), industrial wastewater is assumed to be $25 \%$ of domestic nitrogen (in advanced treatment systems). Spatial downscaling is done according to the population density. (ii) Agriculture: total nitrogen leaching and runoff of nitrogen from agricultural soils is estimated from the DNDC-CAPRI meta-model (2009) and integrated into the IDEAg according to Leip et al. (2009b). In addition to the data presented in Figure 16.2, the data presented here include run-off from livestock housing and manure management systems, which are estimated using the MITERRA approach (Britz and Witzke, 2008; Velthof et al., 2009). Spatial distribution is in accordance with the livestock density per grid cell by animal group. (iii) Forest soils: nitrogen Nr leaching from forest soils is estimated as described in Figure 16.3. (iv) Atmospheric deposition: Atmospheric $\mathrm{N}_{-}$-deposition is calculated with the European-scale EMEP MSC-W Chemical transport model (European Monitoring and Evaluation Programme, Meteorological Synthesizing Centre - West) as described in Figure 16.4.

$\mathrm{N}_{2} \mathrm{O}$ emissions take a larger share of the total denitrification losses with generally narrow $\mathrm{N}_{2} / \mathrm{N}_{2} \mathrm{O}$ ratios around 3-4 in forest soils, but higher values for rough grazing. The forest type is very important in determining the rate and also the type of $\mathrm{N}_{\mathrm{r}}$ emissions, due to its impact on litter quality and soil pH. Pilegaard et al. (2006) carried out a detailed study of $\mathrm{N}_{\mathrm{r}}$ fluxes in 15 forest sites throughout a year and across Europe and found that coniferous forest soils had much higher NO emissions than deciduous forest soils. On the other hand, $\mathrm{N}_{2} \mathrm{O}$ emissions were slightly higher in deciduous forests compared to coniferous ones.

Atmospheric transport and atmospheric deposition is discussed in detail by Simpson et al. (2011, Chapter 14 this volume). In contrast to the figures presented there, we show here absolute deposition fluxes per area of grid cell (Figure 16.4). For the contributions of $\mathrm{N}$-deposition by ecosystem shown in the pie diagram and the histogram, the share of the various ecosystems at the grid scale is taken into account also. Even though cropland covers a smaller area in EU27 than forests, about $40 \%$ of deposition fluxes on the continent go on cropland, more than on forest land, because European forests are predominantly located in areas with smaller atmospheric $\mathrm{N}_{\mathrm{r}}$ concentrations. Forests are the main receptor ecosystem for atmospheric $\mathrm{N}_{\mathrm{r}}$ deposition in Scandinavian countries (Finland 70\% and Sweden 66\%) and alpine regions as Austria (55\%). Deposition over semi-natural land is important in Mediterranean countries (Greece 35\%, Spain 30\%), but also in countries where conditions are too wet for other land uses 

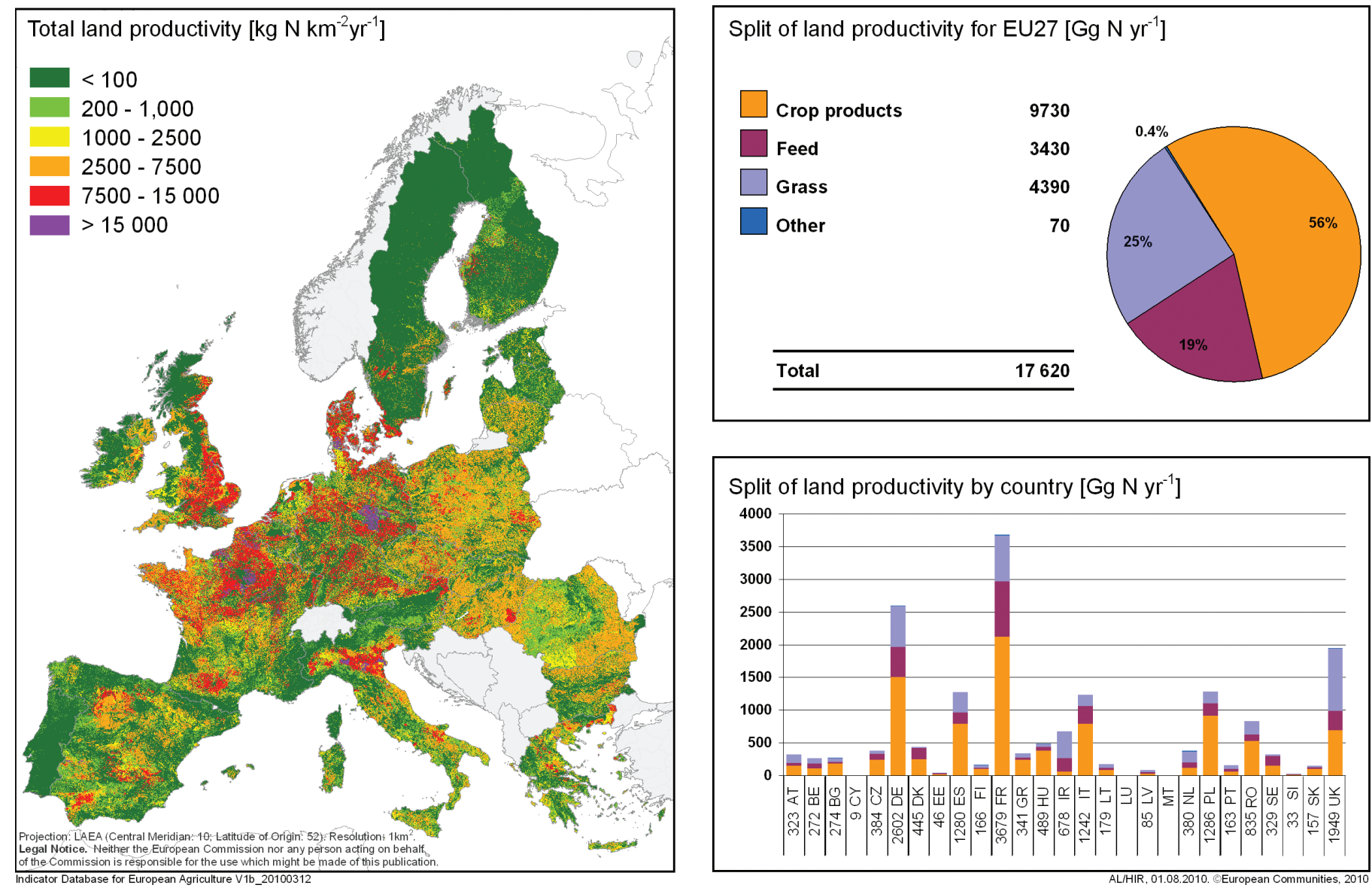

Figure 16.9 Total land productivity of agricultural land in EU-27 for the year 2002. The map shows total agricultural land productivity for a grid of $1 \mathrm{~km} \times 1 \mathrm{~km}$. The values are in $\mathrm{kg} \mathrm{N}$ per total pixel area [ $\mathrm{kg} \mathrm{N} \mathrm{km}^{-2}$ total area]. The pie diagram at the right side gives the split of N productivity [Gg N yr ${ }^{-1}$, rounded to $10 \mathrm{Gg}$ N year ${ }^{-1}$ ] for EU27: crop products, fodder (fodder maize fodder beet and other fodder on arable land), grass and other (flowers, nurseries, etc.). The histogram shows the split of $\mathrm{N}$ productivity $\left[\mathrm{Gg} \mathrm{N} \mathrm{yr}^{-1}\right]$ by country.

Basis: Indicator Database for European Agriculture V1, 2009.

Method: Land productivity is based on CAPRI regional statistics on agricultural and grassland yield with crop-specific nitrogen contents. The data include crop residues that are returned to the soil. As statistics on grassland yields are scarce, these are estimated within CAPRI on the basis of the energy requirement of livestock and energy supply from other feed available (concentrates, fodder). Spatial allocation is done on the basis of simulation results for crop-potential yields (Genovese et al., 2007) under given climatic and soil conditions.

(UK 54\%, Ireland 76\%). Croplands are the main receptor for atmospheric $\mathrm{N}_{\mathrm{r}}$ deposition in Denmark (58\%), Poland (52\%) and Lithuania (51\%). The map shows also deposition fluxes over European shelf regions and deep ocean waters, which are of equal magnitude. Together they receive about $40 \%$ of the $\mathrm{N}_{\mathrm{r}}$ deposited over the continent. The size of the total deposition is largely controlled by agricultural emissions of $\mathrm{NH}_{3}$, which are transported over shorter distances than $\mathrm{NO}_{\mathrm{x}}$ and strongly influence local deposition rates. High deposition regions with deposition rates over $20 \mathrm{~kg} \mathrm{~N} \mathrm{ha}^{-1} \mathrm{yr}^{-1}$ are therefore associated with intensive livestock production, such as in the Netherlands and the Po Valley in Northern Italy. High deposition rates of $>10 \mathrm{~kg} \mathrm{~N} \mathrm{ha}^{-1} \mathrm{yr}^{-1}$ are found almost throughout Central Europe.

\subsubsection{Emissions of reactive nitrogen to the atmosphere and hydrosphere}

Emissions of reactive nitrogen to the atmosphere and the hydrosphere are caused by both agricultural and other land-use activities as well as by fuel combustion and industrial processes. Detailed maps of the spatial distribution of total emissions of $\mathrm{N}_{\mathrm{r}}$ to these media are helpful for understanding the occurrence of hot-spots and could be the first step in identifying appropriate and well-targeted mitigation measures. We show here the most important fluxes of $\mathrm{N}_{\mathrm{r}}$, i.e. total emissions of $\mathrm{NH}_{3}$ (Figure 16.5), total emissions of $\mathrm{NO}_{\mathrm{x}}$ (Figure 16.6) and total emissions of $\mathrm{N}_{2} \mathrm{O}$ (Figure 16.7) to the atmosphere, as well as total $\mathrm{N}_{\mathrm{r}}$ emissions to the hydrosphere (Figure 16.8).

About $95 \%$ of $\mathrm{NH}_{3}$ emissions originate from the agriculture sector. The contribution of agriculture is rather stable across the countries in EU27, with a highest contribution in countries such as Ireland, Spain or Hungary $(98 \%)$. The importance of soil/field emissions (from field application of manures, grazing and fertilizers) versus emissions from manure management systems (animal housing and manure storage) varies between $40 \%$ of emissions from soils in Denmark and 67\% of emissions from soils estimated for Ireland. The reason is, of course, the importance as well as the structure of the livestock sector (grazing versus housing of the animals). As manure has higher 

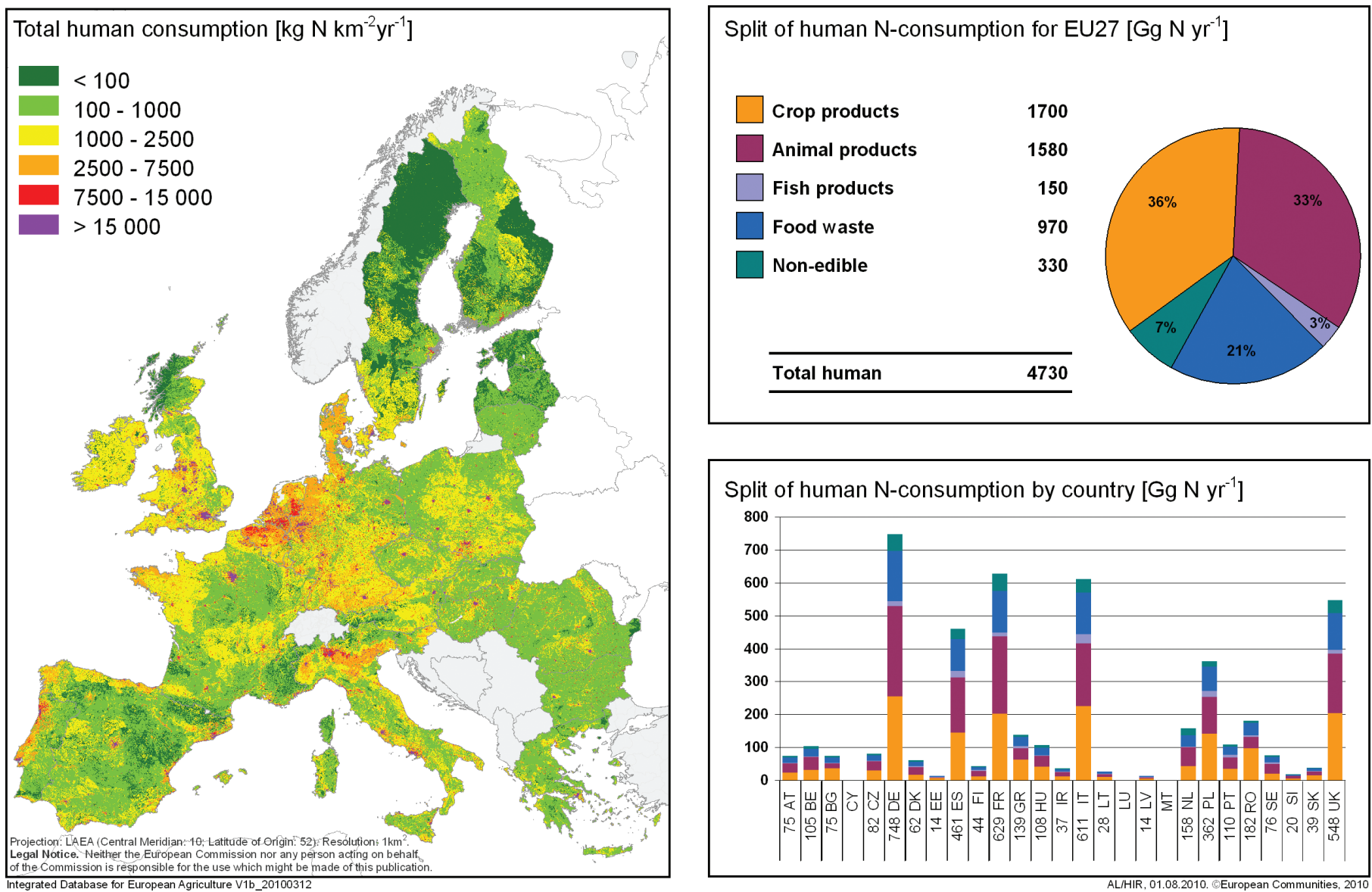

Figure 16.10 Total human N consumption of reactive nitrogen in EU-27 for the year 2002. The map shows human nitrogen consumption of agricultural products including food waste for a grid at of $1 \mathrm{~km} \times 1 \mathrm{~km}$. The values are in $\mathrm{kg} \mathrm{N}$ per total pixel area [kg N km${ }^{-2}$ total area]. The pie diagram at the right side gives the split of human $\mathrm{N}$ consumption [Gg N yr ${ }^{-1}$, rounded to $10 \mathrm{Gg} \mathrm{N}$ year $^{-1}$ ] for EU-27: crop products, animal products, fish products (incl. shellfish), and the $\mathrm{N}$ in non-edible products (peelings, bones) and food waste. The histogram shows the split of human N consumption [Gg N yr ${ }^{-1}$ by country. Basis: Indicator Database for European Agriculture V1, 2009

Method: Consumption is based on CAPRI regional statistics. Spatial allocation is done on the basis of livestock density.

volatilization fractions for $\mathrm{NH}_{3}$ than mineral fertilizer, we find hotspots of $\mathrm{NH}_{3}$ fluxes where the livestock density is high, both in intensive production systems with housed animals such as in the Po Valley, Italy, Denmark, and the Netherlands, as well as in regions with a predominance of grazing animals such as in Ireland. Intensive animal production systems have mainly developed in the vicinity of large metropolitan areas, as the banlieue of the Paris area, but also west of Berlin. The metropoli$\tan$ areas themselves however, are usually low emitters of $\mathrm{NH}_{3}$. Hotspots of $\mathrm{NH}_{3}$ fluxes are found in the major European plains such as the Po Valley, North Germany, the Netherlands and Bretagne, but also in hilly regions such as the Alps in Southern Germany or also, for example, the north of Andalucia.

$\mathrm{NO}_{\mathrm{x}}$ emissions arise mainly from industrial and energysources accounting for $96 \%$ of emissions. Only $4 \%$ of $\mathrm{NO}_{\mathrm{x}}$ emissions are formed biogenically, with $3 \%$ from agriculture and $1 \%$ from forests, according to the estimates presented here. Butterbach-Bahl et al. (2008) give a range of $48.8-128.9 \mathrm{Gg} \mathrm{N} \mathrm{yr}^{-1}$ for $\mathrm{NO}_{\mathrm{x}}$ emissions from agricultural soils depending on the methodology used, which matches well with the presented number of $76 \mathrm{Gg} \mathrm{N} \mathrm{yr}^{-1}$ from agricultural soils (including emissions from pasture), to which about $32 \mathrm{Gg} \mathrm{N} \mathrm{yr}^{-1}$ emissions of $\mathrm{NO}_{\mathrm{x}}$ from manure management systems are added. For forest soils, Butterbach-Bahl et al. use the process-based model Forest-DNDC as the only approach and give a number of 75 $\mathrm{Gg} \mathrm{N} \mathrm{yr}{ }^{-1}$, which is about twice as large as the $32 \mathrm{Gg} \mathrm{N} \mathrm{yr}^{-1}$ in our estimate from the INTEGRATOR model. The numbers do not include $\mathrm{NO}_{\mathrm{x}}$ emissions from forest fires and burning of agricultural residues, which are available in the Global Fire Emissions Database (GFED) (van der Werft et al., 2010). According to these data, about $11 \mathrm{Gg}$ of $\mathrm{NO}_{\mathrm{x}}-\mathrm{N}$ are released to the atmosphere by burning of woodland and forests (about $75 \%)$ and agricultural waste (25\%).

The bulk of $\mathrm{NO}_{\mathrm{x}}$ emissions originate from combustion processes - about equal amounts of $\mathrm{NO}_{\mathrm{x}} \mathrm{-N}$ are emitted from stationary combustion (industry and residential combustion) and mobile combustion (mainly road transport) with $42 \%$ of total emissions or about $1.5 \mathrm{Tg} \mathrm{N} \mathrm{yr}^{-1}$ each. It is important to note that emissions from aviation and navigation are divided between domestic and international transport. While the emissions from international navigation/aviation are included in the spatially allocated emissions, they do not appear in national 

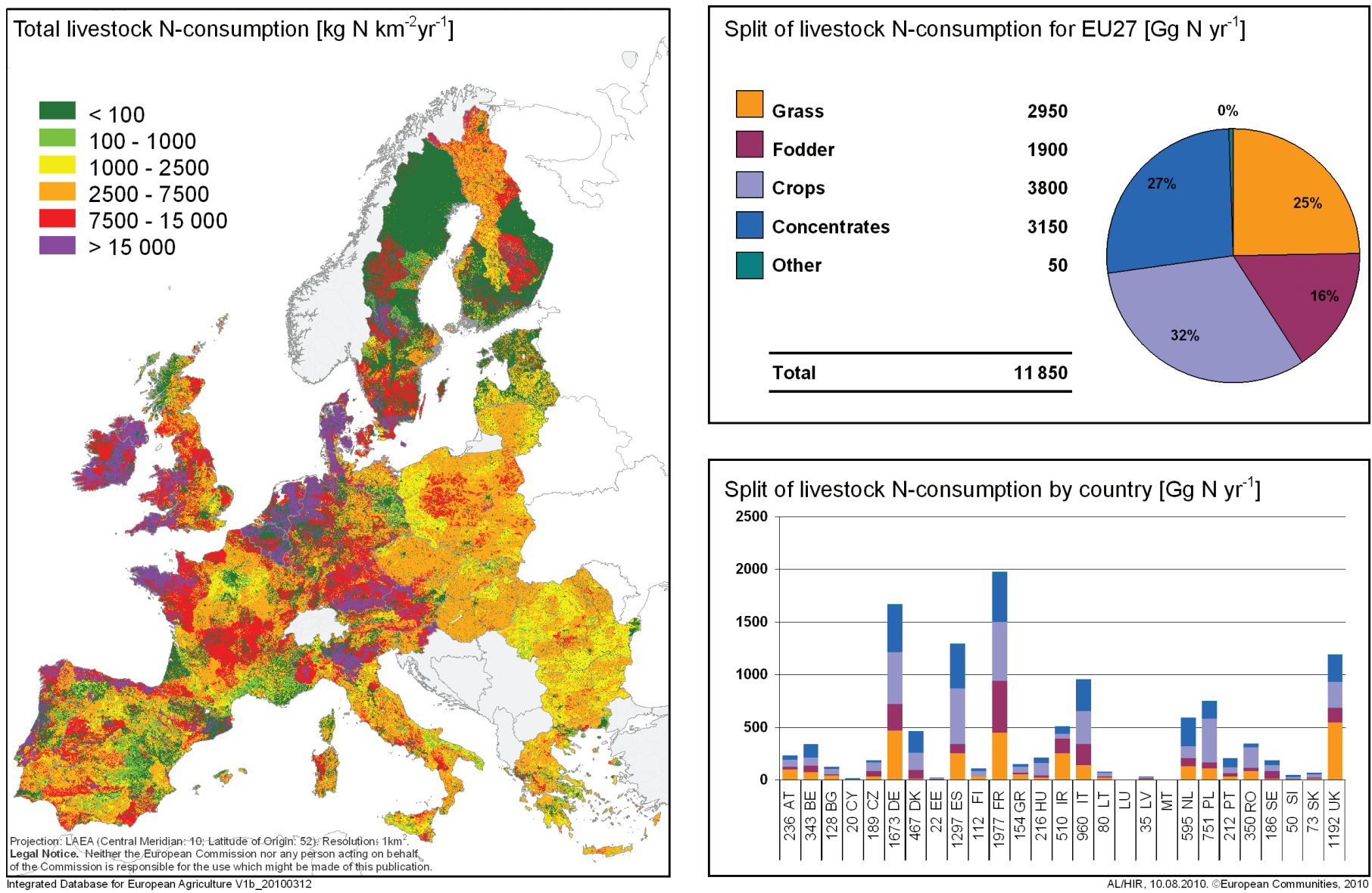

Figure 16.11 Total livestock N consumption of reactive nitrogen in EU-27 for the year 2002. The map shows human nitrogen consumption of agricultural products including food waste for a grid at of $1 \mathrm{~km} \times 1 \mathrm{~km}$. The values are in $\mathrm{kg} \mathrm{N}$ per total pixel area [kg N km $\mathrm{k}^{-2}$ total area]. The pie diagram at the right side gives the split of livestock $\mathrm{N}$ consumption [Gg N yr ${ }^{-1}$, rounded to $10 \mathrm{Gg} \mathrm{N}$ year $^{-1}$ ] for EU-27: grass (cutting and grazing), fodder (fodder maize, fodder beet and other fodder on arable land), crops (cereals and other non-fodder crops, mainly leguminous crops and oilseeds), concentrates (energy-rich and protein-rich concentrates, oilseed cakes, milk powder, molasse, etc.) and other (straw, animal products). The histogram shows the split of livestock $\mathrm{N}$ consumption [Gg $\mathrm{N}$ yr ${ }^{-1}$ ] by country.

Basis: Indicator Database for European Agriculture V1, 2009.

Method: Consumption is based on CAPRI regional statistics and Eurostat national statistics for fish products with crop-specific nitrogen contents. Spatial allocation is done on the basis of population or livestock density for the consumption of food or feed, respectively.

totals. Military emissions, which are estimated to be small, are not included. Additional details on the transport sector are given in Section 16.4.

The highest share of industry-combustion to total $\mathrm{NO}_{\mathrm{x}}$ emissions is observed in Central-Eastern European countries such as Romania (43\%), Poland (47\%), or the Czech Republic (48\%). In Poland, residential combustion is also considerable ( $21 \%$ of total $\mathrm{NO}_{\mathrm{x}}$ emissions). The importance of residential $\mathrm{NO}_{\mathrm{x}}$ emissions depends on the fuel mix and the energy efficiency; the share of residential emissions to total $\mathrm{NO}_{\mathrm{x}}$ emissions in Italy and France are relatively high with $15 \%$ and $20 \%$, respectively, and low in Finland and Estonia (both 7\%). Accordingly, the map of total $\mathrm{NO}_{\mathrm{x}}$ emissions shows high values in centres of energy-intensive industry, such as Sachsen-Anhalt in Germany, North Italy, the Netherlands, or along intensive traffic lines. In many cases, both have been developed along major river streams as can be observed for the Rhine where we find large industry complexes but also an important traffic axis.

The main sources of $\mathrm{N}_{2} \mathrm{O}$ are biogenic sources including agricultural soils, manure management, as well as forest soils and the waste sector, accounting together for $74 \%$ of all $\mathrm{N}_{2} \mathrm{O}$ fluxes in EU27. Processes leading to $\mathrm{N}_{2} \mathrm{O}$ formation in soils, as well as the upscaling of $\mathrm{N}_{2} \mathrm{O}$ fluxes from these sources for both agricultural and non-agricultural terrestrial sources, are discussed in Chapters 6 and 15 (Butterbach-Bahl et al., 2011, this volume; De Vries et al., 2011, this volume). Agricultural soils are the main source contributing $73 \%$ of biogenic $\mathrm{N}_{2} \mathrm{O}$ sources with manure management systems, forests and the waste sector contributions at $7 \%, 8 \%$ and $2 \%$, respectively. The contribution of the waste sector to biogenic $\mathrm{N}_{2} \mathrm{O}$ emissions ranges from $1 \%$, for example in Finland, the Netherlands and Poland, to $16 \%$ in Denmark. Agricultural soils contribute to almost $90 \%$ of biogenic $\mathrm{N}_{2} \mathrm{O}$ emissions in Hungary, Greece and Finland, while the smallest contribution of soils being estimated for Estonia (45\%).

The most important non-biogenic sources of $\mathrm{N}_{2} \mathrm{O}$ are industrial processes, which are not caused by fuel combustion, but by the industrial processes themselves. The chemical industry is an important source of $\mathrm{N}_{2} \mathrm{O}$ emissions accounting for $20 \%$ of EU27 $\mathrm{N}_{2} \mathrm{O}$ emissions. Globally, nitric acid production is the most important $\mathrm{N}_{2} \mathrm{O}$ source within the chemical industry, 
followed by adipic acid, caprolactam and glyoxal production. As industrial plants are point sources with an uneven distribution, the significance of industry ranges from $0 \%$ of national $\mathrm{N}_{2} \mathrm{O}$ emissions in Poland, Portugal and the UK to more than $60 \%$ in Denmark. Additionally, $\mathrm{N}_{2} \mathrm{O}$ is used in anaesthesia and in aerosol spray cans.

The spatial structure of $\mathrm{N}_{2} \mathrm{O}$ emissions is thus a combination of the one observed for $\mathrm{NH}_{3}$ (mainly livestock) and $\mathrm{NO}_{\mathrm{x}}$ (mainly energy and transport). Thus, we find those areas which were already identified for both other gases such as the Po Valley, the Netherlands, and Sachsen-Anhalt, but also identify high fluxes from rural agricultural areas such as Hungary or Poland.

The map of $\mathrm{N}_{2} \mathrm{O}$ fluxes is further complicated by its large dependency on environmental conditions. The soil type is a particularly important factor, which tends to increase fluxes in Northern Europe, where soils with a high content of organic carbon prevail, and leads to lower fluxes in Southern Europe with soils of lower organic carbon content, but this trend is overlaid with the influence of soil moisture and temperature (see Leip et al., 2010b).

The input of reactive nitrogen to European aquatic systems is dominated by point sources through sewage systems, including industrial fluxes and diffuse sources from agriculture. Thus, the $\mathrm{N}_{\mathrm{r}}$ load to rivers is highly correlated with population density as can be seen from Figure 13.10 in Billen et al. (2011, Chapter 13 this volume). This is superimposed on the pattern of agricultural nitrogen leaching, which is similar to the spatial pattern of agricultural nitrogen surplus shown in Figure 16.2. Runoff in agricultural systems from stables or manure management systems and leaching from forest soils are estimated to be of minor importance.

Data on the distribution of sewage systems are available for most European countries from EUROSTAT, EEA (1998), Wieland (2003) and Jeppsson et al. (2002). The overall values for these removal fractions for a country are calculated as the weighted average of the four classes as compiled for the IMAGE model by Van Drecht et al. (2009). In the IMAGE model it is assumed that $\mathrm{N}_{\mathrm{r}}$ emitted by people not connected to sewerage systems will be retained and does not enter the hydrosphere. In rural areas of Europe, however, the majority of human wastes will be discharged to unmonitored small sewage plants, or to septic tank/soakaway facilities. In the UK, for example, these are the dominant point sources in most rural catchments, in comparison to the major sewage treatment plants in larger towns or cities. We assumed that the $\mathrm{N}_{\mathrm{r}}$ from such unmonitored small sewage plants or septic tanks/soakaways undergoes a 'biological-treatment' like transport to the river/groundwater system.

A detailed study on the nitrogen removal efficiency of sewage treatment systems in the UK (Johnes, 1996) takes in to account the fact that although the process is optimized in larger sewage treatment plants in urban areas, in many of the older treatment systems, in rural areas and in most of the coastal towns and villages, volumes treated have exceeded initial design capacity through local population growth or migration. As a consequence, only mechanical treatment is available for part of the $\mathrm{N}_{\mathrm{r}}$, with little biological treatment of wastes, particularly during cold, wet periods. The same is true for peak seasons, for example in tourist regions (e.g. alpine ski resorts in the winter; beach and lake vacation regions in the summer and spring), when the $\mathrm{N}_{\mathrm{r}}$ input to sewage systems exceeds their capacity.

\subsubsection{Secondary nitrogen indicators}

In this section we present secondary reactive nitrogen indicators that answer two important questions: what is the amount of proteins (nitrogen) that European crop- and grasslands can currently produce and what is the amount of proteins (nitrogen) that European inhabitants (humans and livestock) consume? The first map shows total land productivity (Figure 16.9), defined as the sum of harvested crops, and grazed biomass according to the soil system budget. Included in the total productivity are crop residues that are or are not used for other purposes (as animal feed or bedding material, biofuels or burned), which is in contrast to the definition of nitrogen autotrophy (see Billen et al., 2011, Chapter 13 this volume), which gives its production of food and feed only (harvested and grazed products; Billen et al., 2007, 2008).

The second and third map show human consumption of nitrogen (Figure 16.10) and the consumption of nitrogen by livestock (Figure 16.11). Both are split by the main proteinsources, i.e. crops, livestock products and fishery products for human consumption and grass, crops/fodder and concentrates for livestock consumption. The sum of both maps gives the nitrogen heterotrophy in Europe.

A large part of rural Europe is characterized by a high degree of regional specialization of agricultural activities. In most traditional agrarian systems in Europe, livestock farming used to be a critical component, providing a way to ensure cropland fertility by bringing to it, $\mathrm{N}_{\mathrm{r}}$ extracted from seminatural $\mathrm{N}_{2}$ fixing areas in the form of manure. During the past half century, in parallel with increasing urbanization, many lowland rural areas of Europe have shifted either towards exclusive crop production, with very little cattle breeding, or to intensive livestock farming, supported to a large extent by feed importation. Mixed farming areas are restricted to highland or mountainous regions. As a result of this specialization, the exchange of food and feed over long distances has considerably increased and now often represents quite a significant share in the nitrogen budget of regions, or even of countries.

Still, the total productivity of agricultural land is particularly high in the hinterland of large metropolitan areas (e.g. Paris, Berlin, London) and in areas of intensive animal production (the Netherlands, Belgium, Po Valley, Italy, many areas of England and Ireland). About $45 \%$ of the productivity yields crop products, while the other $50 \%$ of nitrogen are distributed over dedicated fodder production ( $20 \%$, fodder maize and fodder beet) and grassland (25\%). The significance of grass varies largely between 5\% in Denmark and 60\% in Ireland while the importance of feed production varies between 10\% (Bulgaria, Greece) to over $40 \%$ (Sweden, Estonia).

Human consumption obviously peaks in metropolitan areas like Paris, London and Berlin which are clearly visible in the map and consume more than $15 \mathrm{MgN} \mathrm{yr}^{-1}$ per square kilometre. Outside 
these hotspots, human $\mathrm{N}_{\mathrm{r}}$-consumption is generally between 200 and $2000 \mathrm{~kg} \mathrm{~N} \mathrm{yr}^{-1} \mathrm{~km}^{-2}$. There is about $36 \%$ consumption of crop products and $33 \%$ consumption of animal products, with a small fraction (3\%) of fish products consumed. The last third is estimated to be either non-edible or wasted. In many central-western countries intake from animal proteins dominales while in countries like Greece, Romania and Bulgaria about $70 \%$ of protein intake is from vegetable sources.

Livestock $\mathrm{N}_{\mathrm{r}}$-consumption follows the livestock density and thus the same regions with high/low rates can be identified that were already visible particularly in the $\mathrm{NH}_{3}$ map (Figure 16.5). The consumption of crop products by livestock is more than double the consumption of crop products by the human population, a value that increases to 3.8 and 9.3 in Ireland and Denmark. About the same amount of concentrates is being fed to animals as crop products, and about $40 \%$ of animal feed is stemming from grass and fodder. However, we find large differences in animal nutrition across the countries with some countries feeding almost $50 \%$ with concentrates, as in the Netherlands, Portugal and Denmark, while this share is only $12 \%-13 \%$ in Latvia, Romania countries and the Czech Republic. The share of grass is naturally high in mountainous countries like Austria, but also in lowland countries such as Ireland and the UK. In all cases, grass contributes to more than $40 \%$ of the protein requirements of animals.

Urban areas, where food is consumed but not produced, are obviously heterotrophic. Rural regions specialized into crop production are autotrophic and export nitrogen as food and/ or feed, while those characterized by intensive animal farming sustained by imported feed are usually heterotrophic as in those regions the import of feed is usually not balanced by exported food products.

\subsection{Integrated nitrogen budgets}

Integrated nitrogen budgets are defined here as the quantification of all major nitrogen fluxes across sectors and media within given boundaries, and fluxes across these boundaries, on an annual basis. They provide a valuable tool for optimizing the benefits of policies addressing imbalances evident in the nitrogen cascade. These policies have often been designed to achieve a specific goal, neglecting unwanted side effects such as pollution swapping. Integrated nitrogen budgets per se do not directly give a quantification of the risk of such pollution swapping effects, as these are determined by mechanistic effects and require an understanding of the dynamics of the nitrogen fluxes. However, in many instances, integrated nitrogen budgets can give a good indication of where $\mathrm{N}_{\mathrm{r}}$ pollution is most severe and where swapping problems from one medium to another might occur.

Here, a standardized integrated Nitrogen Budget (iNB) approach has been implemented to derive a suite of national integrated nitrogen budgets (NiNB) as well as the European Nitrogen Budget (ENB). Each of the NiNBs has been compiled by national experts from each country, using data available at national scale. For each iNB, five sectors are differentiated: industry and energy, transport, agriculture, forestry and natural terrestrial ecosystems, and waste. Each sector has a pool of $\mathrm{N}_{\mathrm{r}}$ and is connected to the others by three transport media: the atmosphere, the hydrosphere, and the consumers who transport, for example, agricultural products to the waste management systems. Pools of $\mathrm{N}_{\mathrm{r}}$ are hard to quantify and are often not incorporated; however stock changes are important indicators to detect possible accumulation or depletion of $\mathrm{N}_{\mathrm{r}}$ and their implications for soil productivity, biodiversity or the development of human health problems.

Conceptually, the ENB contains the same kind of information as NiNBs and they can thus be discussed together. From a methodological point of view, however, the ENB is largely model-based (see Section 16.4.2) as robust and consistent estimates for many elements of a NiNB at the European level are not currently available.

\subsubsection{National integrated nitrogen budgets}

National integrated nitrogen budgets (NiNB) help in visualizing the main elements of the $\mathrm{N}$ cascade within a country into a figure that might transmit its main messages at a quick glance, but nevertheless contains sufficient detailed information for further analysis. Therefore, a NiNB is regarded as a very efficient policy instrument and an important tool to help prioritize policies. In particular, NiNBs can serve five objectives: (i) they are an efficient instrument for visualizing the $\mathrm{N}$ cascade and its potential impact and thus help to raise awareness; (ii) NiNBs provide policy makers with information for developing efficient emission reduction measure; (iii) more importantly, they can provide a tool for monitoring the impact and environmental integrity of implemented policies; (iv) NiNBs are useful for comparisons across countries; and (v) they can help pinpoint knowledge gaps and thus contribute to improving our scientific understanding of the $\mathrm{N}$ cascade.

Often, NiNBs have to rely on information of different origin and quality, and therefore it may not be possible to 'close' the budget for one or several sectors. $\mathrm{N}$ fluxes presented in NiNBs are ideally based on a sufficiently dense network of observational data or on detailed models calibrated and validated on national conditions; however, often data gaps have to be filled from simpler models of a broader scope such as the models used for the European Nitrogen Budget.

To build a NiNB is thus a challenging task and many elements of a budget will only be quantifiable within a very high uncertainty range, for example the amount of nitrogen denitrified and released as the stable and harmless $\mathrm{N}_{2}$ gas; or sedimented and stored for potential future release in the oceans. The magnitude of the uncertainty itself is usually unquantified.

Despite these difficulties, NiNBs have been developed for some countries or are in the process of being developed.

- Switzerlandformulated environmental targets for agriculture in 1996 based on the observation that additional efforts were required to minimize pollution of soil, air and water and to maintain biodiversity. Measures in the agriculture sector were found to be particularly cost-efficient. The recommendations built on the Swiss $\mathrm{N}$-budget that had been 
developed for the year 1994. The Swiss N-budget was updated for the year 2005 and published by the Federal Office for the Environment (BAFU, 2010).

- The Netherlands is a country facing significant $\mathrm{N}_{\mathrm{r}}$ pollution problems, such as particularly high nitrate concentrations in the groundwater, as well as a decrease in biodiversity and forest vitality, high atmospheric $\mathrm{NO}_{x}$ and $\mathrm{NH}_{3}$ concentrations leading to human health effects, and algal blooms in the North Sea (Erisman et al., 2005). The Dutch nitrogen budget was estimated by Erisman et al. (2005) on the basis of an analysis by van Grinsven et al. (2003) and also proposed a list of measures to address the $\mathrm{N}_{\mathrm{r}}$ pollution problems in the Netherlands.

- In Germany the Federal Environment Agency (UBA) released a draft national nitrogen budget as background information to the Integrated Strategy for the Reduction of Nitrogen Emissions in April 2009 (Umweltbundesamt, 2009a,b), motivated by the fact that despite major efforts most environmental targets (halting loss of biodiversity, national emission ceilings for $\mathrm{NO}_{\mathrm{x}}$ and $\mathrm{NH}_{3}$, concentration of nitrate in drinking water, mitigation of global climate change) appeared unlikely to be met and that only an integrated approach would support the development of cost-efficient and effective solutions. Whereas the strategy contains a set of measures, the budget contains very detailed information on all quantifiable nitrogen fluxes across sectors and interfaces between environmental media above $1 \mathrm{Gg} \mathrm{N} \mathrm{yr}^{-1}$.

- In France, the construction of the nitrogen budget has been initiated with the aim of developing an overarching vision of the nitrogen cascade between industrial sectors and environmental compartments through cooperation between various French research institutes and agencies. The development of the N-budget is ongoing and results are preliminary.

- The United Kingdom has built a national N-budget using the iNB approach, based on a detailed N-budget for agriculture following the OECD approach (DEFRA, 2008), national scale $\mathrm{N}$ flux modelling to freshwater and coastal systems and to and from the atmospheric $\mathrm{N}$ pool, and published data on non-agricultural sectoral fluxes. Further work is warranted to refine and update the initial budget presented here.

- The Czech Republic has launched a project to estimate all $\mathrm{N}$-fluxes following the German example. To that purpose, the Czech Hydrometeorological Institute (CHMI) is cooperating with the Ministry of Agriculture and with the Central Institute for Supervising and Testing in Agriculture. CHMI is providing a range of emission and deposition data. Other institutions calculate $\mathrm{N}$ fluxes with regard to, for example, feed, manure, agricultural products, waste and leaching. Cooperation with the Institute of Geology and other institutes is planned.

Other countries, like Turkey have recently started developing a national $\mathrm{N}$-budget.
Figures 16.12-16.17 show the national integrated nitrogen budgets for countries in Europe available to date. Each NiNB is constructed from nationally available information and thus the budgets are not directly comparable. For example, river export has not been estimated in Germany, while it constitutes a significant flux in the Netherlands and Switzerland. Additional details on the data sources of the NiNBs and the outcomes of the respective projects are given in the supplementary information (see supplementary material Chapter 16, Section A).

As the NiNBs are not constructed with a harmonized or even comparable methodology, a comparison of single flux estimates must be done with care. Nevertheless, they highlight the general differences across the countries, as can be seen by ranking emissions by sector and dominant $\mathrm{N}_{\mathrm{r}}$ form of emissions. Such an assessment is shown in Figures 16.18-16.20. For example, nitrogen fluxes in the Netherlands are dominated by industrial $\mathrm{N}_{\mathrm{r}}$ fixation. The export of $\mathrm{N}_{\mathrm{r}}$, mainly as fertilizer, is by far the largest $\mathrm{N}$-flux and feed-imports are higher than the input of mineral fertilizer. By contrast, in Switzerland the combined estimate of atmospheric $\mathrm{N}_{\mathrm{r}}$ deposition plus biological $\mathrm{N}$ fixation to agriculture is higher than the input of mineral fertilizer and feed imports. Both countries have an important exchange of $\mathrm{N}_{\mathrm{r}}$ with other countries or the sea through river flow. In the Netherlands, the $\mathrm{N}_{\mathrm{r}}$ transit through the country as import and export are roughly the same. However, in Switzerland, river export is the single most important sink for the country exporting more $\mathrm{N}_{\mathrm{r}}$ than is applied to agricultural soils as mineral fertilizer.

A summary of the national $\mathrm{N}$-budgets presented above by main compartment or sector (Table 16.2) shows that balance is not closed for most sectors. These N-budgets give aggregated data for countries, without a spatial dimension such as was shown in the key maps above. Not all nitrogen fluxes have been (or could be) estimated yet, and, secondly, the data for different compartments and sectors have been taken from the best available, but to some extent inconsistent, data sets. Examples include atmospheric deposition (which in many countries has been obtained from the EMEP model) and atmospheric emissions, which can have data sources which are partly inconsistent with the information used in the EMEP model. The main gap between the sum of $\mathrm{N}_{\mathrm{r}}$ emissions to and removals from the atmosphere is due to fluxes of molecular nitrogen $\left(\mathrm{N}_{2}\right)$ through $\mathrm{N}$ fixation and denitrification, which are difficult to estimate and have not been quantified for many countries/compartments. Therefore a negative balance is observed for most countries. The agriculture sector, which is in many countries one of the best-described sectors as gross nitrogen balance calculations have been made with the OECD methodology (OECD/ Eurostat, 2003), ideally gives a closed soil N-budget, yet the link to consumers and/or the industry has often been obtained from different sources. Un-quantified stock changes in agricultural soils can potentially account for part of the positive (accumulation) or negative (depletion) balance in agriculture. The French NiNB does not yet include fluxes from agriculture to the consumer or to the hydrosphere and the data show therefore a considerable gap. 


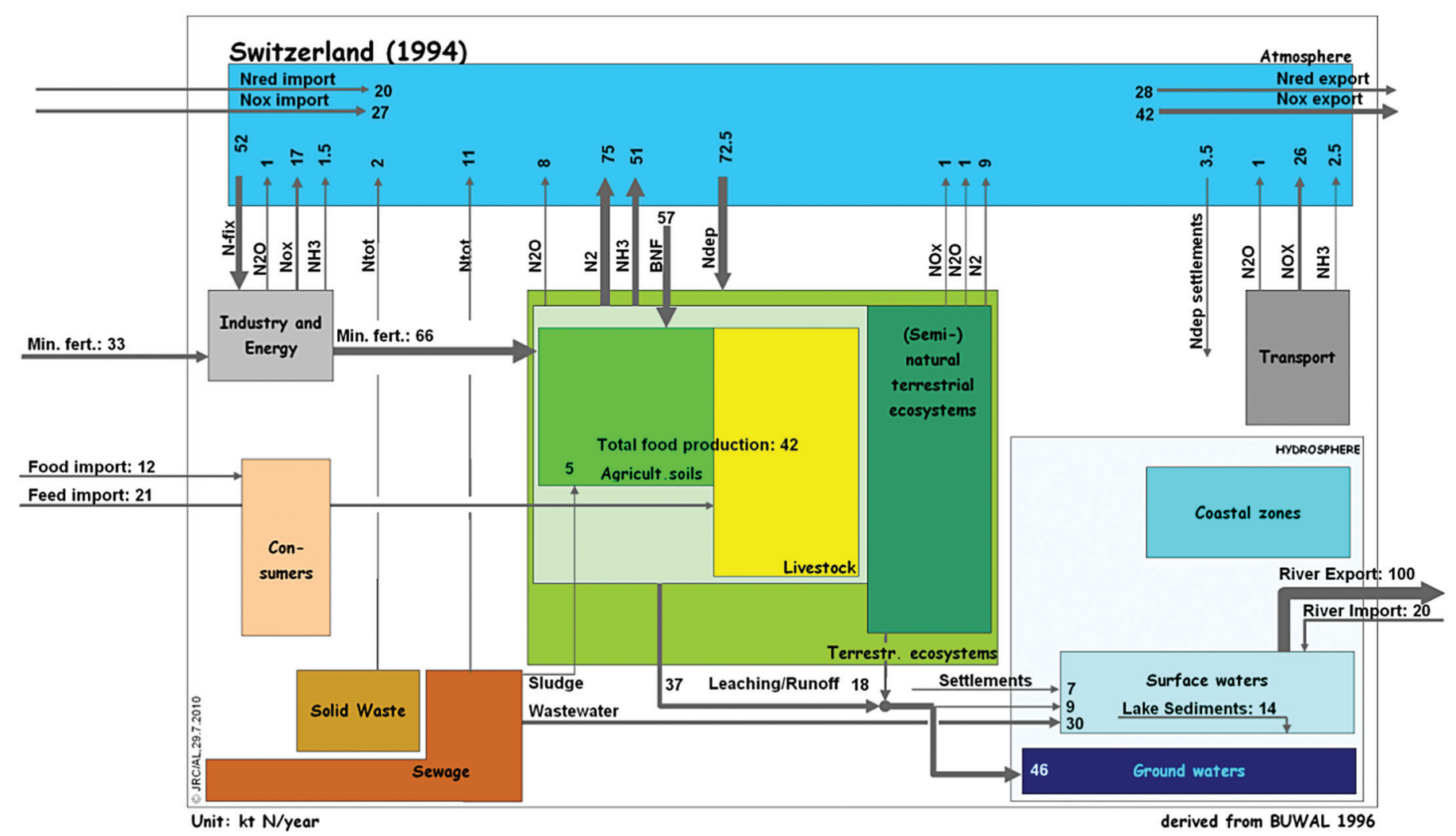

Figure 16.12 A national integrated nitrogen budget for Switzerland, derived from a study that was carried out between 1994 and 1996 based on a mandate of the Departments of Economic Affairs and Home Affairs of the Swiss government. The project aimed at identifying the most important N fluxes between the all compartments, at assessing the fluxes with respect to the exceedance of effects-based environmental and health quality criteria, and at elaborating a strategy for a stepwise reduction of emissions of reactive nitrogen. The results of the work of the project group are summarized in the report. "Strategy for the Reduction of Nitrogen Emissions" (BUWAL, 1996).

One of the largest fluxes is the generation of $\mathrm{N}_{\mathrm{r}}$ in the industry and energy sector. This $\mathrm{N}_{\mathrm{r}}$ has three important sources: (a) nitrogen fixation with the Haber-Bosch process, (b) release of nitrogen from fossil energy carriers such as coal, and (c) thermal generation of $\mathrm{N}_{\mathrm{r}}$ at high temperatures during the burning process. For the NiNBs presented, total industrial/ energy $\mathrm{N}$-fixation has been estimated as the difference between total estimated $\mathrm{N}$-outputs and inputs in these sectors, to give an indication of the order of magnitude of this N-flux.

A positive $\mathrm{N}$-balance is found for the consumers. While food input and $\mathrm{N}$-output to sewage systems is quantified in most cases, the underlying assumptions may differ. Not all biomass produced is edible; not all edible parts will be consumed; and assumptions on the fate of the produced biomass are associated with considerable uncertainty (see discussion on the European Nitrogen Budget). The waste-streams are often poorly quantified in the NiNBs presented. The consumer has a central role in national N-budgets: with excess-supply in most European countries the incentives for 'nitrogen-efficient' behaviour are not currently well developed to affect consumers' behaviour. The choices of consumers nonetheless steer the societal machinery with major consequences for the nitrogen budget.

In addition to input of nitrogen as biomass, the consumer receives also significant amount of industrial nitrogen, as plastics, pigments or other chemical products. The fate of these products is not yet quantified and appears as a (positive) balance as these substances accumulate in the anthroposphere.

An overview of emissions to the atmosphere is given in Figure 16.18. Generally, agriculture is the main emitter of $\mathrm{N}_{\mathrm{r}}$ to the atmosphere and to the hydrosphere (Figure 16.19), but taking all combustion sources together (incl. industry), atmospheric emissions from combustion are roughly at the same level as agricultural emissions, with the exception of the United Kingdom. The United Kingdom is the country where industrial and energy emissions play the biggest role: emissions to the atmosphere from combustion sources are almost twice as large as the emissions from agricultural sources. Nevertheless, as extensive agricultural activities involves high mineral fertil-

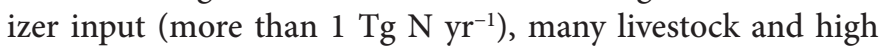
precipitation, this country estimates the highest leaching rate to waters (almost $0.5 \mathrm{Tg} \mathrm{N} \mathrm{yr}^{-1}$ ).

Emissions to the hydrosphere have not been estimated yet in the French N-budget, however, this country is characterized by extensive agricultural activity reflected both in the input of mineral fertilizer nitrogen $\left(2.5 \mathrm{Tg} \mathrm{N} \mathrm{yr}^{-1}\right)$ and high atmospheric emissions ( $>0.7 \mathrm{Tg} \mathrm{N} \mathrm{yr}^{-1}$ ). The high land productivity throughout almost the whole territory of France (see also Figure 16.9) makes the country independent of feed-imports (only $7 \%$ of mineral fertilizer-input or $175 \mathrm{Gg} \mathrm{N} \mathrm{yr}^{-1}$ ). 


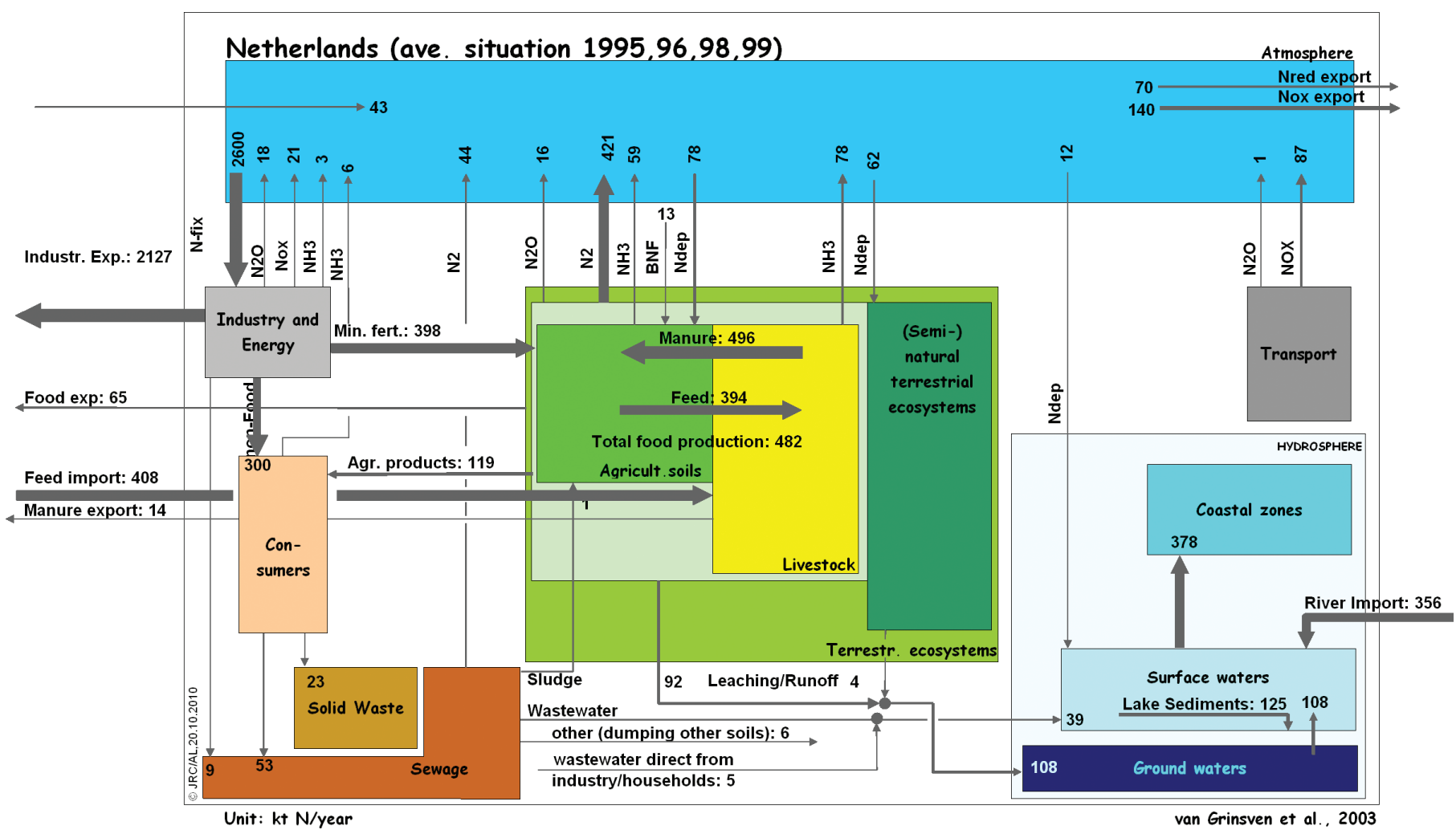

Figure 16.13 The Dutch national nitrogen budget is based on information from different publications, mainly originating from the National Bureau of Statistics. The data shown represent the average situation of 1995, 1997, 1998 and 1999 (van Grinsven et al., 2003).

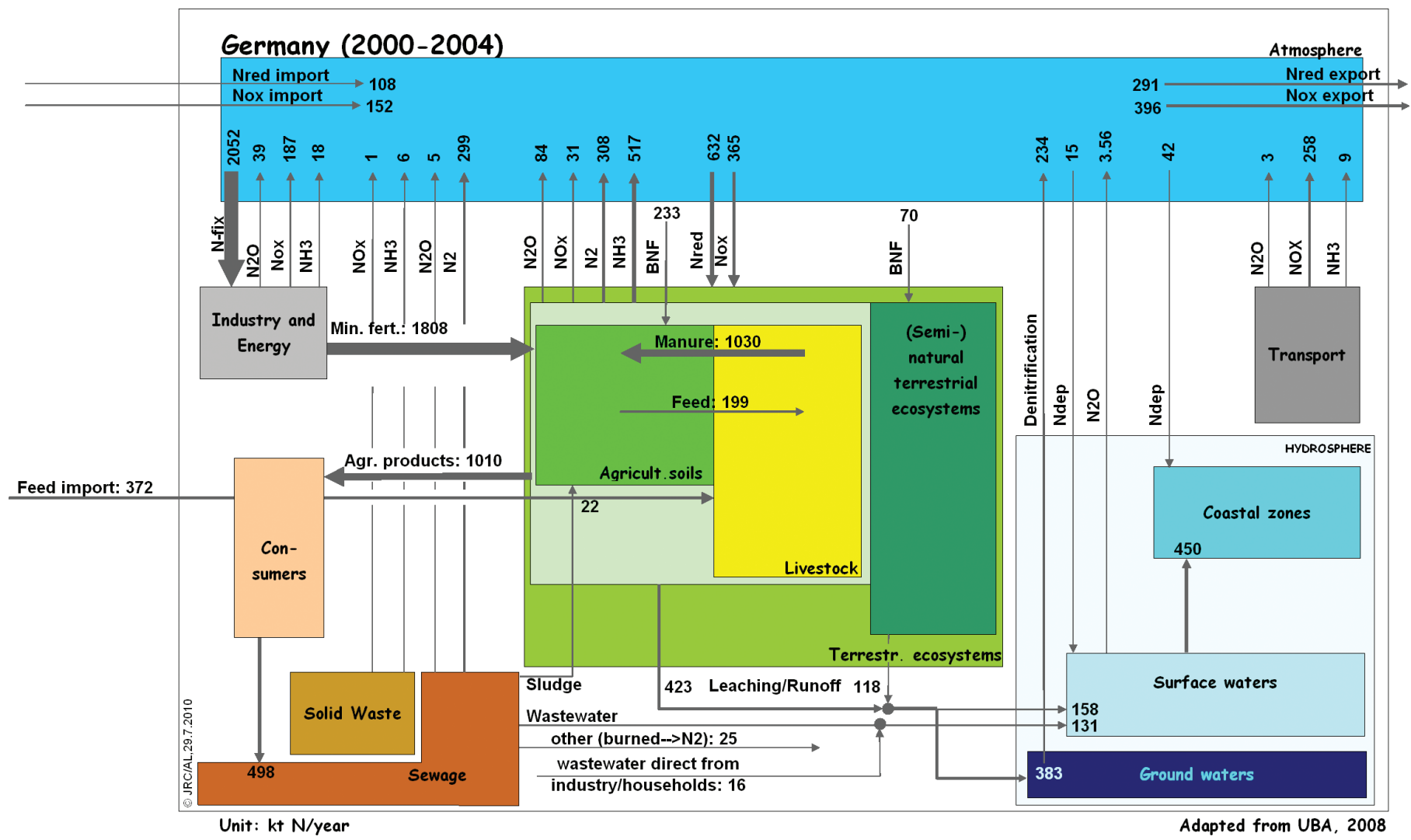

Figure 16.14 The national nitrogen budget for Germany has been calculated by the Federal Environment Agency (Umweltbundesamt, 2009). The data is compiled of official, national emission, deposition and flux data sets for the years 2000-2004. The most important fluxes are emissions to atmosphere, deposition, input into hydrosphere and following export to coastal ecosystems. 


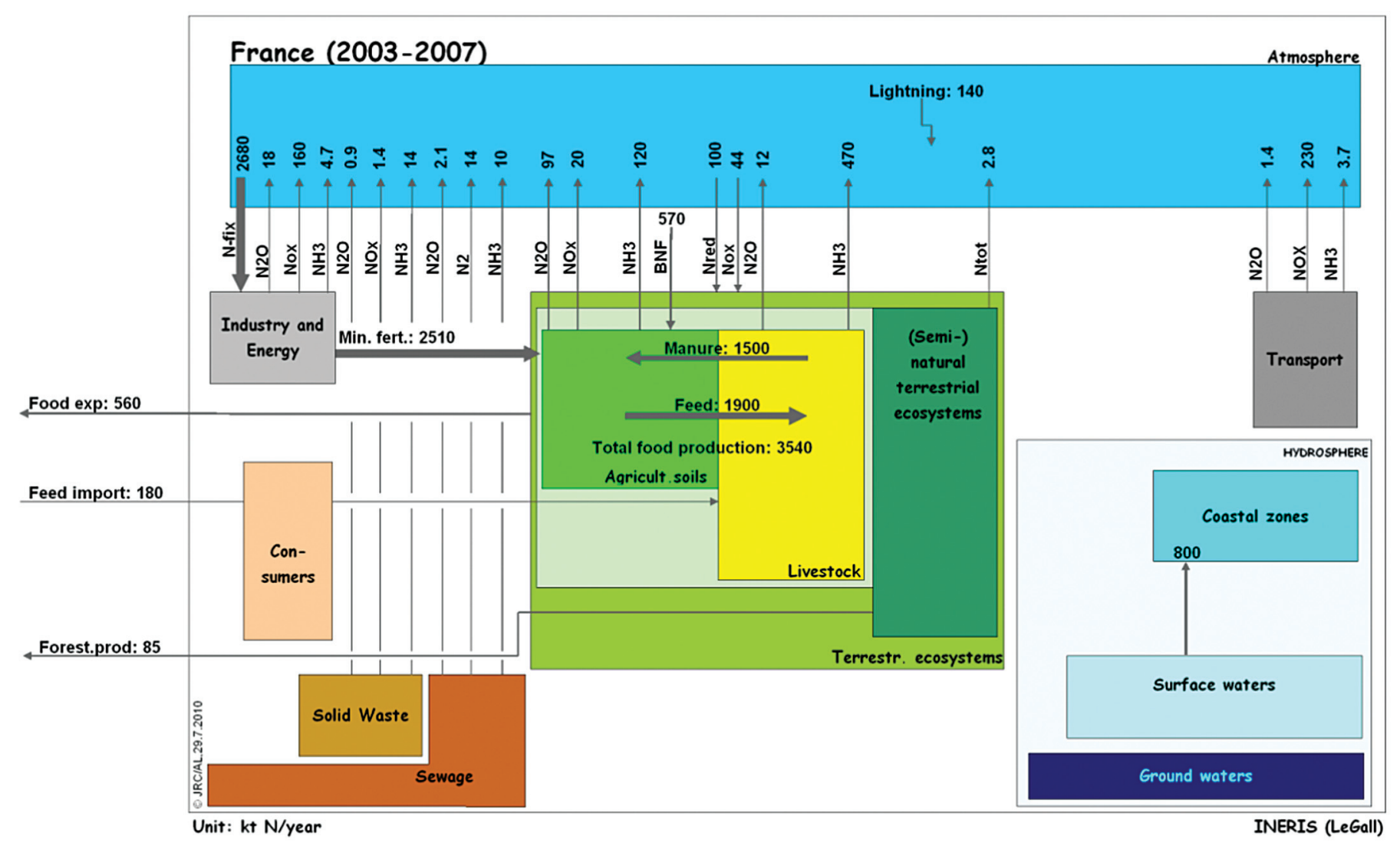

Figure 16.15 National nitrogen budget for France calculated with data gathered between 2003 and 2007 (Personal Communication Groupe de travail français sur l'azote réactif, or French working group on reactive nitrogen). The construction of the French national N-budget is an ongoing process, and the figures are therefore preliminary results which are bound to be modified.

The split of atmospheric emissions over the three reactive nitrogen gases $\mathrm{NO}_{\mathrm{x}}, \mathrm{NH}_{3}$, and $\mathrm{N}_{2} \mathrm{O}$ reflects again the weight of the energy versus the agriculture sectors of the considered countries (see Figure 16.20).

\subsubsection{The European Nitrogen Budget (ENB)}

Galloway et al. (2008) formulated five vexing questions that should guide the direction of nitrogen research in the near future. The first of them relates to the ultimate fate of reactive nitrogen, and particularly the role of denitrification in soils and freshwater systems that are not well constrained. Based on the information presented above and in previous chapters, the development of an integrated N-budget for Europe is attempted. This European Nitrogen Budget. It covers the territory of the EU27 countries, with the exception of Malta and Cyprus (limited by the availability of data from the Indicator Database for European Agriculture).

The European Nitrogen Budget, in contrast to most national N-budgets, is almost completely model-based, combining a model for agriculture, forestry, industrial emissions and atmospheric deposition into a common framework as given in Table 16.1. The restriction to a few models reduces the number of conflicting data as each of the models ensures consistency in the data sets used and $\mathrm{N}_{\mathrm{r}}$ fluxes estimated. Inconsistencies at the interfaces between the models can not be excluded, though they are usually small as the models deal with complementary sectors. For example, the nitrogen deposition fluxes to agricultural and (semi-) natural soils obtained from the latest simulations of the EMEP model for the year 2000 differ from the figure used in the IDEAg and INTEGRATOR models, based on slightly older versions. This points towards the need for a better fine-tuning and integration of the models, even though the differences are not large. Surprisingly, the atmospheric compartment shows a good match of total $\mathrm{N}_{\mathrm{r}}$ emissions with total $\mathrm{N}_{\mathrm{r}}$ deposition plus net export of nitrogen, even though the emission data are obtained from the above-mentioned models and the EDGAR-CIRCE database for industrial and energy sources, which are to some extent independent of the emission data used for the EMEP model. We are not aware of a Europewide model estimating $\mathrm{N}_{\mathrm{r}}$ fluxes for surface waters and coastal areas and here the ENB had to be complemented by individual flux estimates taken from literature. In this chapter, we focus on nitrogen fluxes in the present time (year 2000). Nevertheless, a European nitrogen budget for the year 1900 has been developed too and is presented in the supplementary information (see supplementary material Chapter 16, Section B).

When looking at the ENB, one has to keep in mind that the numbers presented are associated with large uncertainties which are difficult to quantify. The extent to which errors or biases in input data, model assumptions and model parameterizations propagate to the aggregated model output is hard to assess. In 


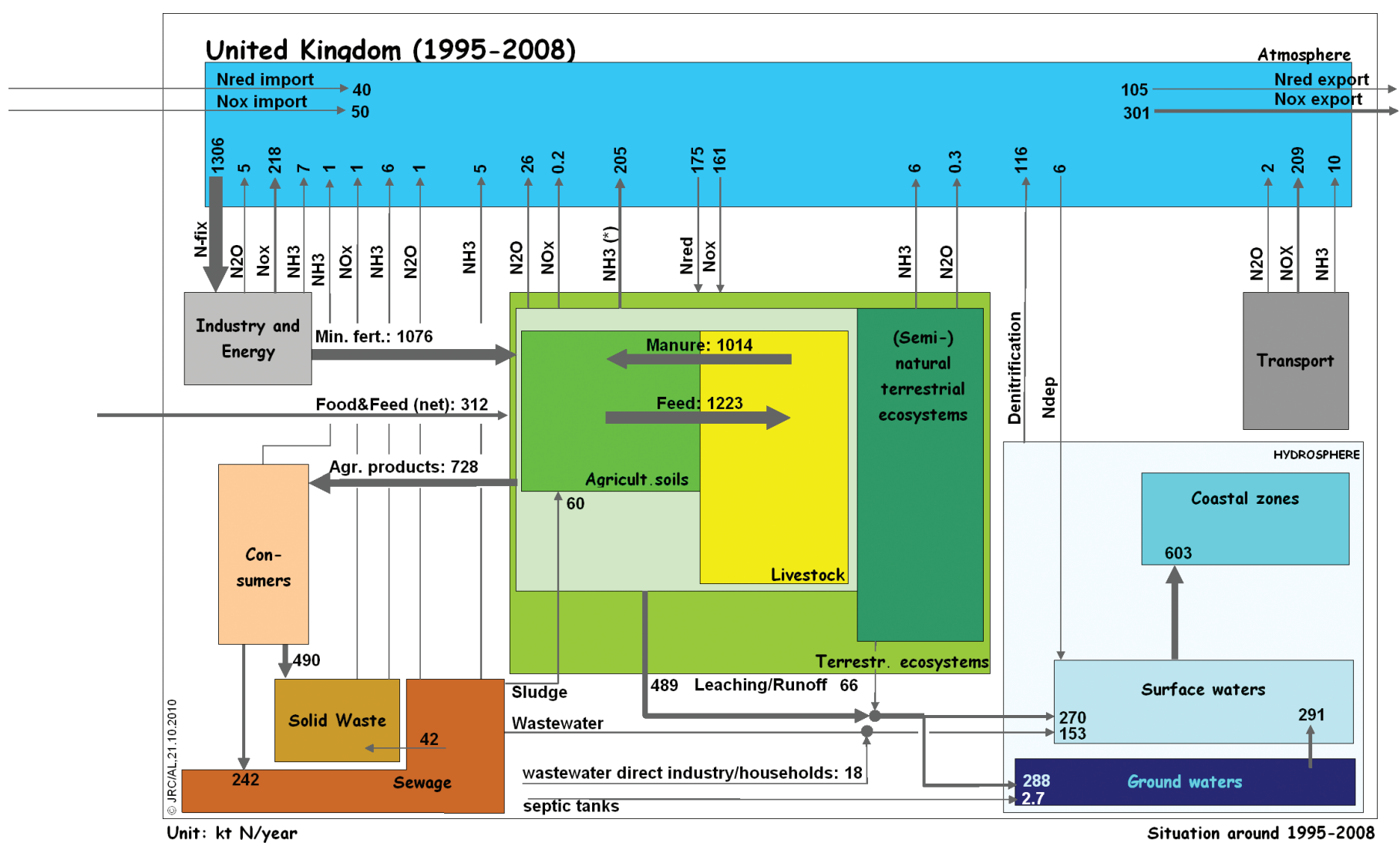

Figure 16.16 The integrated nitrogen budget of the United Kingdom builds on the UK TAPAS modelling for agriculture (DEFRA), providing data on mineral fertilizer application rates and manure management and on the national food and feed balance modelling (DEFRA, 2008), national N flux modelling to freshwaters and the coastal zone (Johnes and Butterfield, 2002), the UK national emissions inventory and atmospheric transport and deposition modelling and a range of literature sources for UK waters. The data sets are not, however, co-incident in time, and the present budget represents the period from 1995-2005. Work is currently underway to update the budget.

the absence of sufficient observational data that allow the construction of independent estimates, two routes are possible: (i) the comparison of model results driven by the same set of input data (see de Vries et al., 2011, Chapter 15 this volume) and (ii) a systematic assessment of the uncertainty of input data and model structural parameters and their impact on the model outcome at the large scale with Monte Carlo analysis. Both routes are currently followed in the NitroEurope Integrated Project and the results will shed some light on the reliability of estimated $\mathrm{N}_{\mathrm{r}}$ fluxes. Additionally, for some $\mathrm{N}_{\mathrm{r}}$ fluxes, it is indeed possible to use data from atmospheric concentration measurements to quantify the strength of total $\mathrm{N}_{\mathrm{r}}$ emissions for some components (e.g. $\mathrm{N}_{2} \mathrm{O}$ ) using inversion tools which are independent of the models used in the construction of the ENB; also this route is followed in the NitroEurope project (Sutton et al., 2007).

Figure 16.22 gives the nitrogen budget for the main sectors and compartments considered in the ENB. The atmospheric compartment comprises only fluxes of $\mathrm{NH}_{3}$ and $\mathrm{NO}_{\mathrm{x}}$ as input and wet- and dry deposition as output. The large fluxes of molecular nitrogen, in particular $\mathrm{N}$-fixation in the industry and energy sectors and denitrification in terrestrial and aquatic ecosystems are poorly quantified and would add another 20-30 $\mathrm{Tg} \mathrm{N} \mathrm{yr}^{-1}$ in input and output. Nitrogen fixation occurs through biological N-fixation and through the Haber-Bosch process, but there is also input of $\mathrm{N}_{\mathrm{r}}$ from fossil energy carriers and newly formed $\mathrm{N}_{\mathrm{r}}$ through thermal reaction. These fluxes are included in the number presented for $\mathrm{N}$-fixation in the energy and industry sector, but are not quantified for the other sectors.

Consumers and the waste sector store an unquantified amount of $\mathrm{N}_{\mathrm{r}}$ in products, but most of the consumed $\mathrm{N}_{\mathrm{r}}$ will accumulate in the wider environment, be land-filled or incinerated. Indeed, according to the numbers presented, more than $50 \%$ of the $\mathrm{N}_{\mathrm{r}}$ made available to consumers appears to have a purpose other than nutrition. While some information on the fate of this $\mathrm{N}_{\mathrm{r}}$ might be available, so far we were not able integrate robust data into the European Nitrogen Budget.

At the European scale, budgets of industry and energy exceed those of agriculture. Agricultural soils can act as a source or a sink for carbon and nitrogen if organic matter is being depleted or accumulated. Our data suggest that a significant part of the nitrogen lost from the agriculture sector originates from mineralization of soil organic matter. A large exchange of nitrogen takes place in coastal areas, which act as a sink of oceanic nitrogen that is denitrified to $\mathrm{N}_{2}$ and $\mathrm{N}_{2} \mathrm{O}$ in the shelf regions of Europe. As a consequence, the flux of the $\mathrm{N}_{2}$ from these regions might be the largest single nitrogen flux in absolute terms and also the estimate for the $\mathrm{N}_{2} \mathrm{O}$ flux from the shelf regions is very high and exceeds, in absolute terms, fluxes from other sectors including agriculture.

The split of atmospheric emissions in EU27 countries by sectors for three reactive gases $\left(\mathrm{NO}_{x}, \mathrm{NH}_{3}, \mathrm{~N}_{2} \mathrm{O}\right)$ and the total is 


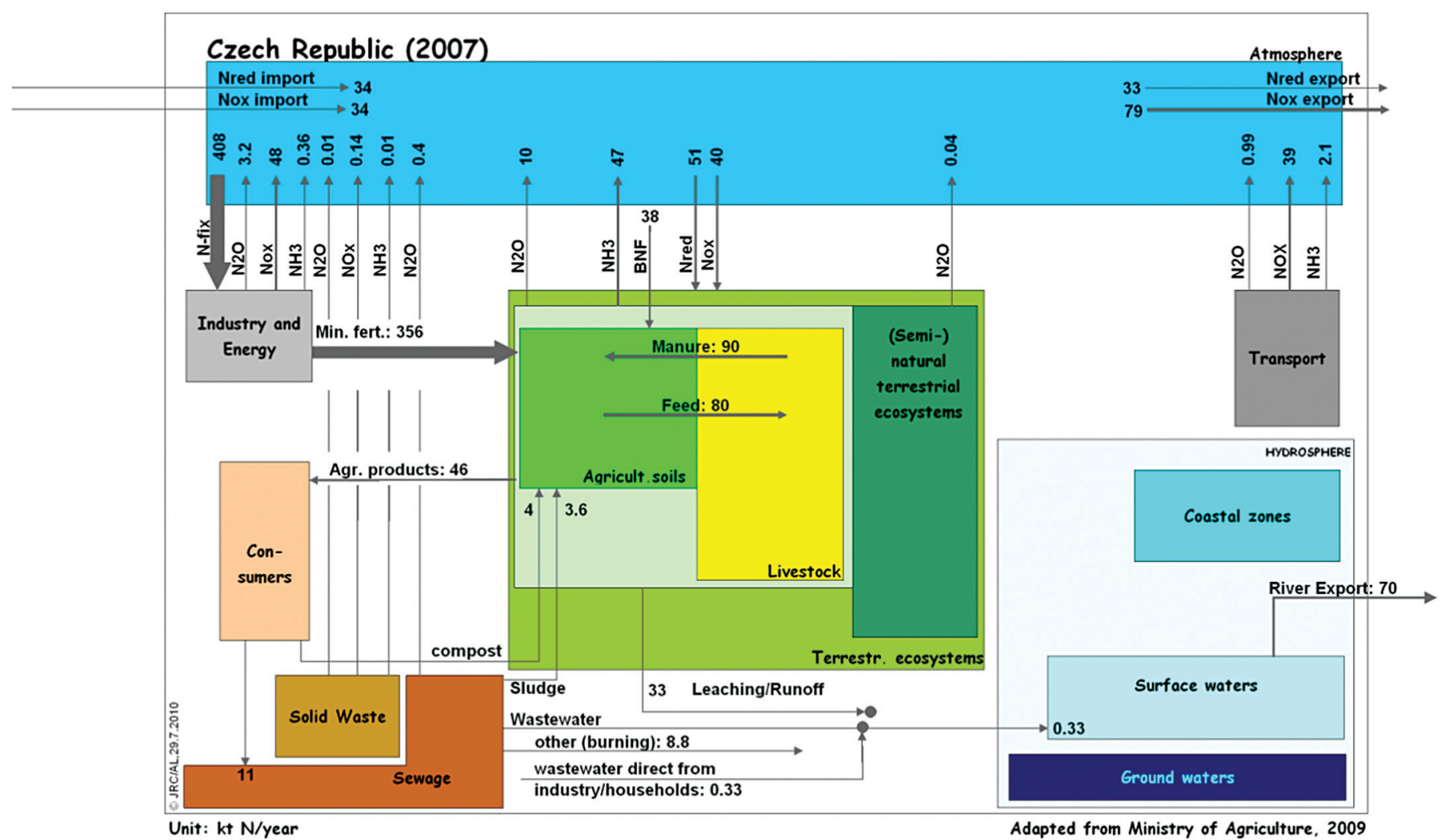

Figure 16.17 The integrated nitrogen budget of the Czech Republic is being constructed by the Hydrometeorological Institute (CHMI) in cooperation with the Ministry of Agriculture and with the Central Institute for Supervising and Testing in Agriculture on the basis of data from different sources (e.g. National Statistical Office) for the years 2004-2008, but mainly for 2007.

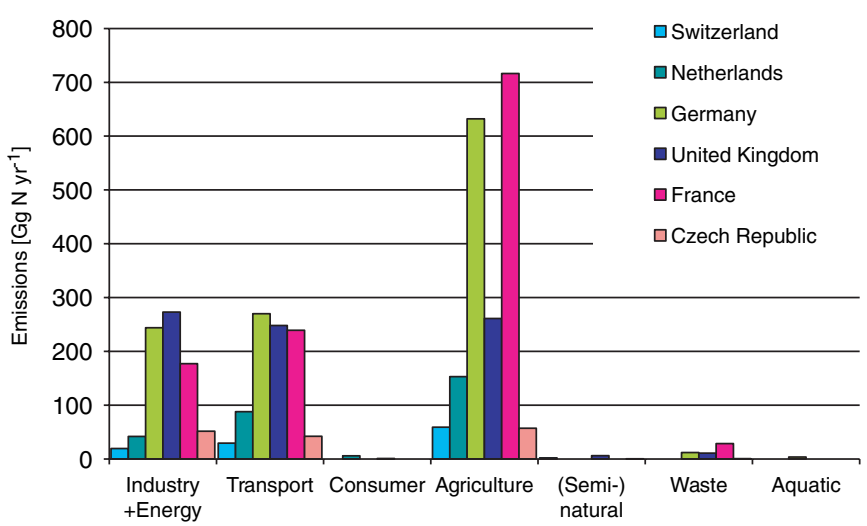

Figure 16.18 Absolute nitrogen emissions to the atmosphere for the main sectors/compartments.

shown in Figure 16.23. The figure shows that $\mathrm{NO}_{\mathrm{x}}$ fluxes dominate the emissions from energy-related sources, $\mathrm{NH}_{3}$ fluxes are the strongest for agricultural sources; the waste sector and aquatic systems emit mainly de-nitrification products $\left(\mathrm{N}_{2}\right.$, $\mathrm{N}_{2} \mathrm{O}$ ). Overall, the emissions for $\mathrm{NO}_{\mathrm{x}}$ and $\mathrm{NH}_{3}$ are roughly at the same level, with $3.5 \mathrm{Tg} \mathrm{NO}_{\mathrm{x}}-\mathrm{N} \mathrm{yr}^{-1}$ and $3.2 \mathrm{Tg} \mathrm{NH}_{3}-\mathrm{N} \mathrm{yr}^{-1}$, respectively.

$\mathrm{N}_{2} \mathrm{O}$ contributes $1.2 \mathrm{Tg} \mathrm{N}_{2} \mathrm{O}-\mathrm{N} \mathrm{yr}{ }^{-1}$. The global warming potential of this greenhouse gas is $580 \mathrm{Tg} \mathrm{CO}_{2 \text {-eq }}$ (using a GWP of 298; IPCC, 2007). This is higher than the emissions of $\mathrm{N}_{2} \mathrm{O}$

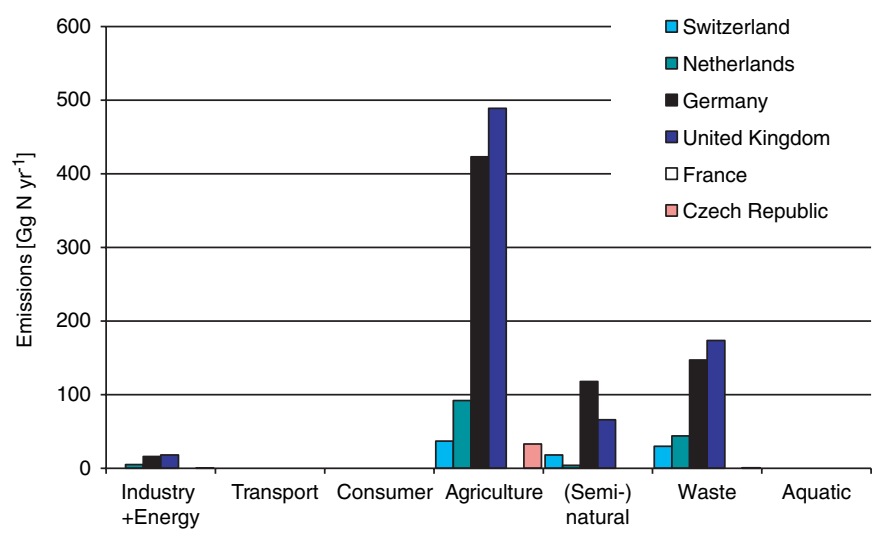

Figure 16.19 Absolute nitrogen emissions to the hydrosphere for the main sectors/compartments.

estimated in the European GHG inventory (EEA, 2010) for the year 2000 (412 $\mathrm{Mt} \mathrm{CO}_{2 \text {-eq }}$ ) which decreased to $364 \mathrm{Mt} \mathrm{CO}_{2 \text {-eq }}$ in the year 2008. However, it should be kept in mind that the ENB emissions include both anthropogenic and natural sources while the greenhouse gas inventories are restricted to anthropogenic emissions only. For example, it is likely that a significant portion of the coastal $\mathrm{N}_{2} \mathrm{O}$ fluxes of $500 \mathrm{Gg} \mathrm{N} \mathrm{N}_{2} \mathrm{O}-\mathrm{N} \mathrm{yr}^{-1}$ (or 230 $\mathrm{CO}_{2 \text {-eq }} \mathrm{yr}^{-1}$ ) originates from nitrogen in incoming oceanic water. In addition, there are methodological differences that influence calculations. IPCC methodology includes indirect emissions 


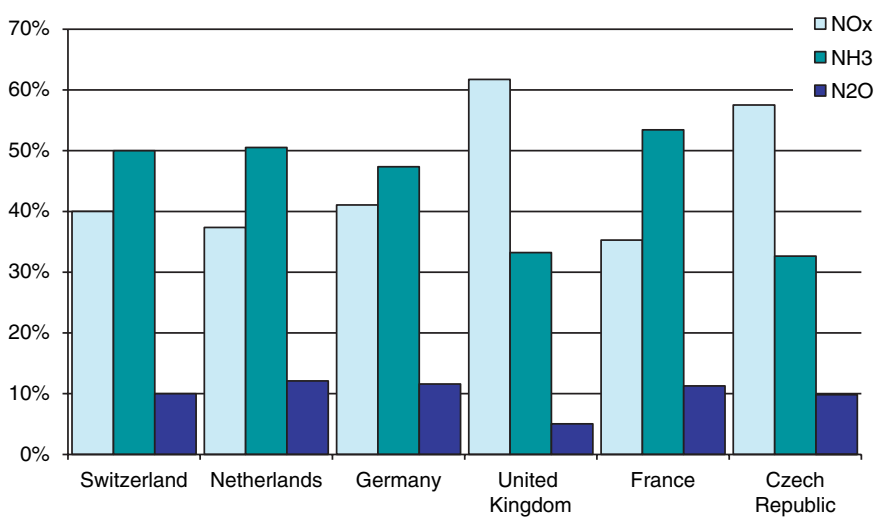

Figure 16.20 Split of total atmospheric emissions over the three reactive gases $\mathrm{NO}_{x}, \mathrm{NH}_{3}$, and $\mathrm{N}_{2} \mathrm{O}$.

from agricultural soils only, while the estimates presented here cover virtually all available land and include implicitly all indirect $\mathrm{N}_{2} \mathrm{O}$ emissions, including those caused by deposition of $\mathrm{NO}_{\mathrm{x}}$ fluxes from the combustion processes. To account for indirect emissions from industrial and energy sources, roughly $20 \mathrm{Mt} \mathrm{CO}_{2 \text {-eq }}$ should be added. Direct $\mathrm{N}_{2} \mathrm{O}$ emissions from agricultural soils for EU27 in 2002 are estimated as $380 \mathrm{Tg} \mathrm{N} \mathrm{N}_{2} \mathrm{O}$, which is about $35 \mathrm{Tg} \mathrm{N}_{2} \mathrm{O} \mathrm{yr}^{-1}$ ( or $15 \mathrm{Tg} \mathrm{CO}_{2 \text {-eq }} \mathrm{yr}^{-1}$ ) more than reported by UNFCCC for the categories 'direct soil emissions' (4D1) and 'pasture, range and paddock manure' (4D2) (EEA, 2010). Thus, agreement for EU27 is satisfying, even though differences are larger for individual countries.

Most of the data used for the ENB are based on the same models as also used for the key maps in Section 16.3. Thus the spatial variability of the most important fluxes is shown in Figures 16.1-16.11.

In the following sections, the main figures presented in the European Nitrogen Budget are briefly reviewed, emphasizing those numbers and sectors which have not yet been introduced in detail elsewhere in the European Nitrogen Assessment.

\section{Industry sector}

The motivation for the invention of the Haber-Bosch process to synthesize reactive nitrogen (ammonia) from atmospheric molecular nitrogen was the urgent need for nitrogen to enable sufficient agricultural food production and the provision of raw material for explosives (Erisman et al., 2008; Sutton et al., 2011, Chapter 1 this volume). As of 2008 around $48 \%$ is the nitrogen synthesized globally by the Haber-Bosch process $(121 \mathrm{Tg} \mathrm{N}$; Erisman et al., 2008). About $24 \mathrm{Tg} \mathrm{N}$ is used in various industrial processes and the production of non-fertilizer products (IFA Statistics, 2010).

Several ammonia-based products are used as fertilizers, in industrial processes and in chemical products. Besides some ammonia salts, other ammonia-based industrial products that are not used as fertilizers include nitric acid, adipic acid, hydrogen cyanides, diisocyanates, acrylonitrile, melamine and others (Domene and Robert, 2001). For Europe, it is estimated that about $30 \%$ of the $\mathrm{N}_{\mathrm{r}}$ fixed with the Haber-Bosch process is used for non-agricultural purposes, including about $4.5 \mathrm{Tg} \mathrm{N}$ in
Western Europe in 2007, and 0.7 Tg N in Central Europe, totalling about 5.2 Tg N (see Winiwarter et al., 2011, Chapter 24 this volume). An accounting of the production of nitrogen-containing substances in Europe is provided in the supplementary information (see supplementary material Chapter 16, Section C). The fate of these products is unknown. The total net trade of EU27 for total $\mathrm{N}$ (fertilizer and non-fertilizer) is estimated to be $1631 \mathrm{Gg} N$ net import. Table 16.3 shows that the trade is dominated by the import of ammonia and urea, while derived products have a slight export-surplus.

\section{Transport sector}

According to the European Environment Agency (EEA) the transport sector accounts for around one third of all final energy consumption in the EEA member countries and for more than a fifth of greenhouse gas emissions (EEA, 2009b). Transport is represented by international and domestic air, sea and inland waterway, off-road and pipeline transport, rail and road transport. It is mainly characterized by the road transport sector, which, in the year 2005 contributed more than $73 \%$ to global transport fuel consumption (EDGARv4, EIA, 2007; IEA/OECD, 2007) followed by air transport ( $\approx 11 \%)$, sea and inland waterways $(\approx 9 \%)$, rail transport $(\approx 4 \%)$ and other transport $(\approx 3 \%)$.

In Europe, road transport has been the dominating source for $\mathrm{NO}_{\mathrm{x}}$ emissions since 1970 (Vestreng et al., 2009). With the implementation of strict measures and action plans in the early 1990s within the framework of the Convention on Longrange Transboundary Air Pollution, European $\mathrm{NO}_{\mathrm{x}}$ emissions were continuously reduced (Pulles et al., 2007). These early measures in Europe complemented clean air initiatives in the US (CONCAWE, 1997) and investigations in the automobile industry enforced by legislation.

The main contributors in road transport producing high $\mathrm{NO}_{\mathrm{x}}$ emissions are heavy duty vehicles (HDV) using diesel fuel and light duty vehicles using gasoline (EMEP/EEA, 2009). With the introduction of EURO standards for light (considering passenger cars) and heavy duty vehicles emission reduction has led to a substantial $\mathrm{NO}_{\mathrm{x}}$ emissions decrease for all vehicles types in Europe. In Western Europe, $\mathrm{NO}_{\mathrm{x}}$ emissions of heavy duty vehicles have been cut by $86 \%$ compared with levels in the 1990s (ACEA, 2009). In contrast, $\mathrm{NH}_{3}$ and $\mathrm{N}_{2} \mathrm{O}$ emissions generally increased in the last years due to the worldwide turnover of vehicle fleets equipped with EURO 3/III standards. Although new emissions standards introduced significant $\mathrm{NO}_{\mathrm{x}}$ emissions reductions, the age structure of a national fleet causes a significant time lag until the new standard can show an effect. Moreover, increasing diesel consumption and increasing growth rates in freight transport volume on a national base (see Lambrecht et al., 2009) prevent further $\mathrm{NO}_{\mathrm{x}}$ emissions decreases. Furthermore, one of the reasons why some air quality problems still persist, even though vehicles have become far cleaner, is that emissions in real driving conditions tend to be higher than emissions under test conditions.

Consequently, of the EU27 Member States, only 15 (up from 10 in 2007) expect to be at, or below, their respective 
Table 16.2 Summary of nitrogen input, output, stock changes and the nitrogen balance for the main compartments/sectors for the National integrated Nitrogen Budgets of the Netherlands, Germany, Switzerland, France, and the United Kingdom. The numbers are summarized from the above figures, thus input and output are the sums of arrows pointing to or from the respective compartments with the exception of nitrogen fixation of $\mathrm{N}_{2}$ (both in industry and biological $\mathrm{N}$-fixation), which is regarded as new $\mathrm{N}_{\mathrm{r}}$ input. Stock changes refer only to quantified stock changes in terrestrial ecosystems (soil stock changes or standing biomass in forests) and aquatic systems (sedimentation in lakes or marine waters)

\begin{tabular}{|c|c|c|c|c|c|}
\hline Switzerland & Input & New $\mathbf{N}_{\mathbf{r}}$ & Output & Stock change & Balance \\
\hline Atmosphere & 254 & 0 & 255.5 & 0 & -2 \\
\hline Industry +Energy +Transport & 33 & 53 & 86 & 0 & 0 \\
\hline Consumer & 12 & 0 & 0 & 0 & 12 \\
\hline Agriculture & 92 & 57 & 171 & 0 & -22 \\
\hline (Semi-) natural land & 0 & 0 & 29 & 0 & -29 \\
\hline Waste & 0 & 0 & 48 & 0 & -48 \\
\hline Freshwater & 112 & 0 & 100 & 14 & -2 \\
\hline Marine water & 0 & 0 & 0 & 0 & 0 \\
\hline Netherlands & Input & New $\mathbf{N}_{\mathbf{r}}$ & Output & Stock change & Balance \\
\hline Atmosphere & 791 & 0 & 2975 & 0 & -2184 \\
\hline Industry +Energy +Transport & 0 & 2600 & 2876 & 0 & -276 \\
\hline Consumer & 419 & 0 & 82 & 0 & 337 \\
\hline Agriculture & 885 & 13 & 785 & 0 & 113 \\
\hline (Semi-) natural land & 62 & 0 & 4 & 0 & 58 \\
\hline Waste & 90 & 0 & 90 & 0 & 0 \\
\hline Freshwater & 515 & 0 & 378 & 125 & 12 \\
\hline Marine water & 378 & 0 & 0 & 0 & 378 \\
\hline Germany & Input & New $\mathbf{N}_{\mathbf{r}}$ & Output & Stock change & Balance \\
\hline Atmosphere & 2263 & 0 & 4096 & 0 & -1833 \\
\hline Industry +Energy +Transport & 0 & 2052 & 2052 & 0 & 0 \\
\hline Consumer & 1010 & 0 & 498 & 0 & 512 \\
\hline Agriculture & 2202 & 233 & 2373 & 0 & 62 \\
\hline (Semi-) natural land & 0 & 70 & 118 & 0 & -48 \\
\hline Waste & 514 & 0 & 489 & 0 & 25 \\
\hline Freshwater & 687 & 0 & 688 & 0 & -1 \\
\hline Marine water & 492 & 0 & 0 & 0 & 492 \\
\hline France & Input & New $\mathbf{N}_{\mathbf{r}}$ & Output & Stock change & Balance \\
\hline Atmosphere & 1178 & 0 & 3401.26 & 0 & -2223 \\
\hline Industry +Energy +Transport & 0 & 2683 & 2683 & 0 & 0 \\
\hline Consumer & 0 & 0 & 0 & 0 & 0 \\
\hline Agriculture & 2681 & 569 & 716 & 0 & 2534 \\
\hline (Semi-) natural land & 0 & 0 & 88 & 0 & -88 \\
\hline Waste & 0 & 0 & 42.53 & 0 & -43 \\
\hline Freshwater & 0 & 0 & 797 & 0 & -797 \\
\hline Marine water & 797 & 0 & 0 & 0 & 797 \\
\hline United Kingdom & Input & New $\mathbf{N}_{\mathbf{r}}$ & Output & Stock change & Balance \\
\hline Atmosphere & 1110 & 0 & 2347 & 0 & -1238 \\
\hline Industry +Energy +Transport & 0 & 1417 & 1417 & 0 & 0 \\
\hline Consumer & 728 & 0 & 243 & 0 & 485 \\
\hline Agriculture & 1178 & 0 & 1478 & 0 & -300 \\
\hline
\end{tabular}


Table 16.2 (cont.)

\begin{tabular}{|c|c|c|c|c|c|}
\hline United Kingdom & Input & New $N_{r}$ & Output & Stock change & Balance \\
\hline (Semi-) natural land & 0 & 0 & 72 & 0 & -72 \\
\hline Waste & 260 & 0 & 200.7 & 0 & 59 \\
\hline Freshwater & 719 & 0 & 721 & 0 & -2 \\
\hline Marine water & 605 & 0 & 0 & 0 & 605 \\
\hline Czech Republic & Input & New $N_{r}$ & Output & Stock change & Balance \\
\hline Atmosphere & 219 & 0 & 629 & 0 & -409 \\
\hline Industry +Energy + Transport & 0 & 408 & 408 & 0 & 0 \\
\hline Consumer & 46 & 0 & 51 & 0 & -4 \\
\hline Agriculture & 360 & 38 & 137 & 0 & 261 \\
\hline (Semi-) natural land & 0 & 0 & 0 & 0 & 0 \\
\hline Waste & 51 & 0 & 13 & 0 & 37 \\
\hline Freshwater & 0 & 0 & 70 & 0 & -70 \\
\hline Marine water & 0 & 0 & 0 & 0 & 0 \\
\hline
\end{tabular}

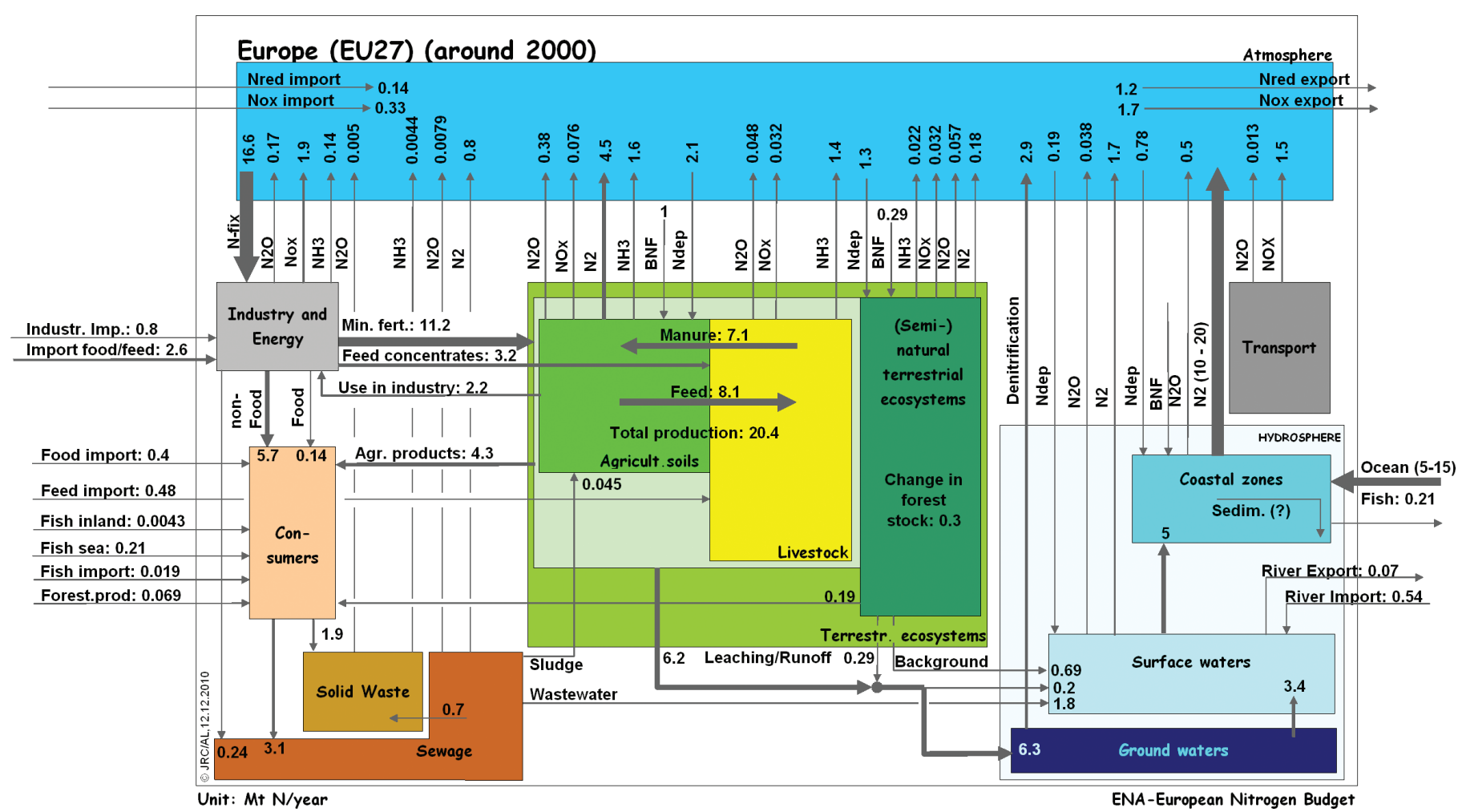

Figure 16.21 Nitrogen budget for Europe (European Nitrogen Budget) for EU-27 compiled with data for the period around the year 2000. Basis: (i) atmospheric transport and atmospheric deposition: EMEP Unified model, rv3.1, 2009. Atmospheric transport is obtained from the source-receptor matrix available at http://www.emep.int/ ; (ii) atmospheric emissions from industry and energy, transport and solid waste systems: EDGAR-CIRCE (Van Aardenne et al., 2009), (iii) industrial trade and non-fertilizer products: Prud'homme, 2009; (iv) agricultural nitrogen fluxes incl. mineral fertilizer use and food and feed trade: Indicator Database for European Agriculture, V1, 2009; (v) (semi-)natural systems: INTEGRATOR, 2009. Export of forestry products: FAOSTAT; (vi) fishery data: Eurostat, 2009 (http://epp.eurostat.ec.europa.eu/portal/page/portal/statistics/search_database); (vii) sewage system fluxes including input of nitrogen and emissions: Indicator Database for European Agriculture, V1, 2009; (viii) fluxes to groundwater and surface water systems including flux from surface waters to coastal zones: IMAGE, 2009; (ix) $\mathrm{N}_{2} \mathrm{O}$ emissions from coastal zones: Bange (2008); (x) other fluxes from coastal zones; see text.

emission ceilings by 2010 (NEC Directive status report 2008, EEA, 11/2009) and $\mathrm{NO}_{\mathrm{x}}$ emissions will be higher than expected. In addition, global emissions are likely to increase due to the strong economic growth in regions such as East Asia (Streets and Waldhoff, 2000), Central Europe and Southeast Asia (e.g. Thailand). Emissions will also increase in the Middle East and Africa, where less policy regulations are in place (Cofala et al., 2007). 


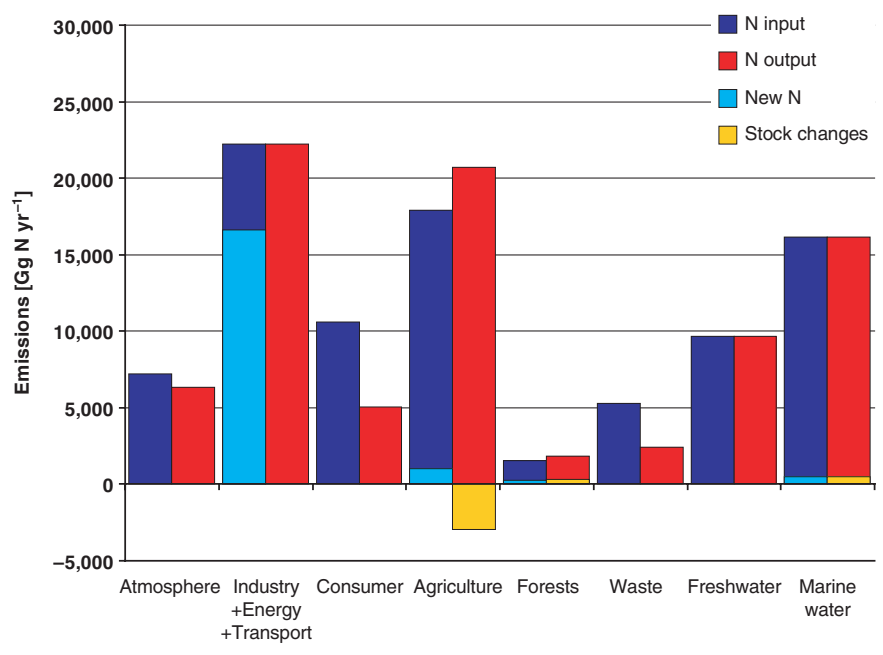

Figure 16.22 Nitrogen balance by main sectors/compartments for EU27 around the year 2000. The contribution of newly generated nitrogen to the $\mathrm{N}$-input as well as the contribution of changes in nitrogen stocks to the $\mathrm{N}$-output (for example sedimentation in lakes and in estuaries) are also shown.

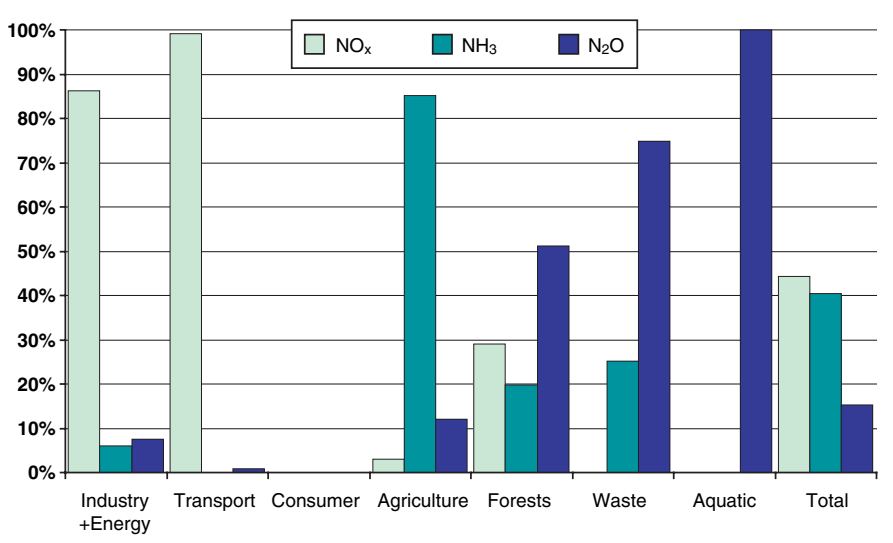

Figure 16.23 Split of atmospheric emissions in EU27 around the year 2000 by sector into the three reactive gases $\mathrm{NO}_{x}, \mathrm{NH}_{3}$, and $\mathrm{N}_{2} \mathrm{O}$.

A particular concern is aviation, which is the fastest-growing transport sector. This growth is partly driven by increasing wealth and low prices (for aviation, fuel tax is currently not considered), which underpin strong growth in tourism travel. Aviation now accounts for more than $10 \%$ of greenhouse gas emissions.

Emission standards for ships and aviation are dealt with by the respective UN organizations (International Maritime Organization, IMO, and International Civil Aviation Organization, ICAO) and by international conventions including the Convention on Long-range Transboundary Air Pollution which also addresses other sectors in addition to transport. Present measures regulate emissions $\left(\mathrm{NO}_{\mathrm{x}}\right)$ on the Landing and Take Off cycle and were designed to address airport air quality problems. The Committee on Aviation Environmental Protection (CAEP) is pursuing new certification methodologies that also take account of the flight mode as well.

Table 16.4 shows that $\mathrm{N}_{\mathrm{r}}$ emissions from civil aviation (Annex 1 countries) increased by 3.5\% from 2000 to 2005, and
Table 16.3 Net trade of nitrogen of Europe (EU27). Values are net export

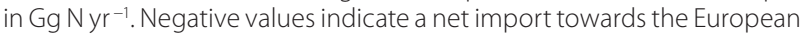
Union

$\begin{array}{lc}\text { Product } & \text { Net export } \\ \text { Urea } & -845 \\ \text { AS } & 298 \\ \text { AN } & 215 \\ \text { CAN } & 141 \\ \text { NPK (estimate) } & 26 \\ \mathrm{NH}_{3} & -1536 \\ \text { UAN (estimate) } & 70 \\ \text { Total } & \mathbf{1 6 3 1}\end{array}$

globally by $9 \%$. The corresponding values for navigation are 13.3\% (Annex 1 countries) and 16.4\% (worldwide). Also the emissions from railway transport will increase with increasing freight transport, which has been restructured in the past 20 years.

\section{Agriculture sector}

Agriculture is the sector with the largest source of reactive nitrogen emissions in Europe as a whole and for each of its countries. We find a high recycling of $\mathrm{N}_{\mathrm{r}}$ between crop production and manure excretion; the livestock sector receives about the same amount of $\mathrm{N}_{\mathrm{r}}$ in the form of domestically produced and imported feed than the grass- and crop-sector. About $60 \%$ of agricultural products (consumed or used in industry) originate from crop production. The nitrogen use efficiency (defined as $\mathrm{N}_{\mathrm{r}}$ in useful products relative to $\mathrm{N}_{\mathrm{r}}$ inputs) for cultivation on soils is about $60 \%$ (considering also $\mathrm{N}$-input through atmospheric deposition and biological nitrogen fixation), while the nitrogen use efficiency for a farm $\mathrm{N}$-budget including animal products drops to about $30 \%$ (Leip et al., 2010a).

Productivity in Europe is high, as has been shown; however, to supply the protein requirements of European citizens, about $400 \mathrm{Gg} \mathrm{N} \mathrm{yr}^{-1}$ of agricultural products for food and about $3 \mathrm{Tg} \mathrm{N} \mathrm{yr}^{-1}$ for feed or industrial use have to be imported. For comparison, Galloway et al. (2008; UNEP and WHRC, 2007) estimate is a significant global trade in fertilizer $(31 \mathrm{Tg} \mathrm{N})$, grain $(12 \mathrm{Tg} \mathrm{N})$ and meat $(0.8 \mathrm{Tg} \mathrm{N})$, and a net import of vegetal products $(2367 \mathrm{Gg} \mathrm{N})$ and meat $(110 \mathrm{Gg} \mathrm{N})$ to Europe. The authors include in their data Eastern Europe, a region which is a large producer and exporter of mineral fertilizer. Therefore, Europe is shown to be a net exporter of fertilizer ( $5376 \mathrm{Gg} \mathrm{N}$ ), neglecting a large internal trade in the European Union (see Table 16.5).

\section{Forestry}

Forests are currently undergoing net growth with net immobilization of $\mathrm{N}_{\mathrm{r}}$ in the soil of about $810 \mathrm{Gg} \mathrm{N} \mathrm{yr}^{-1}$ and a $\mathrm{N}_{\mathrm{r}}$ uptake into the above-ground biomass of $320 \mathrm{Gg} \mathrm{N}$ $\mathrm{yr}^{-1}$ (estimated with the INTEGRATOR model). National 
Table 16.4 Reactive N emission in the years 2000 and 2005 for civil aviation, global aviation, marine activities and navigation and the development in percent from 2000 to 2005

\begin{tabular}{llcccc} 
Sector & Unit & $\mathbf{2 0 0 0}$ & $\mathbf{2 0 0 5}$ & Change (\%) & Reference \\
\hline Civil aviation & Gg Nyr-1 & 98 & 101 & 3.5 & UNFCCC \\
Global aviation & Gg Nyr-1 & 820 & 894 & 9.1 & EDGAR-CIRCE \\
Marine and navigation & Gg Nyr & 1966 & 2229 & 13.3 & UNFCCC \\
Global shipping & Gg Nyr-1 & 3398 & 3954 & 16.4 & EDGAR-CIRCE
\end{tabular}

\begin{tabular}{|c|c|c|c|}
\hline & & $\begin{array}{l}\text { Export } \\
\text { from } \\
\text { Europe }\end{array}$ & $\begin{array}{l}\text { Import to } \\
\text { Europe }\end{array}$ \\
\hline \multirow[t]{5}{*}{ Fertilizer } & North America & 2352 & \\
\hline & South America & 2268 & \\
\hline & Africa & 359 & 639 \\
\hline & SE-Asia & 977 & \\
\hline & Australia & 59 & \\
\hline \multirow[t]{5}{*}{ Grain } & North America & & 423 \\
\hline & South America & & 2318 \\
\hline & Africa & 193 & \\
\hline & Russia & 81 & \\
\hline & SE-Asia & 100 & \\
\hline \multirow[t]{2}{*}{ Meat } & South America & & 82 \\
\hline & Russia & & 28 \\
\hline
\end{tabular}

estimates of carbon sequestration in the land use/land use change and forestry (LULUCF) sector are about $25 \mathrm{Tg} \mathrm{CO}_{2 \text {-eq }}$ (EEA, 2009a). The main uncertainty in converting this value into sequestered $\mathrm{N}_{\mathrm{r}}$ (or stock changes in forests) is the ratio of sequestered carbon in above-ground material and soils, which differ considerably on the $\mathrm{C} / \mathrm{N}$ ratio. As a rough assumption we use $50 \%$ of carbon sequestered in soils, giving stock changes of about $300 \mathrm{Gg} \mathrm{N}$ for EU27. From FAO statistics and national data we obtain a figure of 380 million $\mathrm{m}^{3}$ of total roundwood production in EU27 for the year 2000. Converted to nitrogen uptake/removal from forests this gives approximately $190 \mathrm{Gg} \mathrm{N}$, using a basic wood density of 0.4 for average temperate and boreal trees (see IPCC, 2006), a carbon/dry-biomass ratio of 0.5 and a $\mathrm{C} / \mathrm{N}$ ratio around 400 (see Katri et al., 2004). Part of this wood is used for domestic burning and the resulting emissions are included in the energy/industry figures calculated in the EDGAR database. The remaining biomass will be used in paper and wood products. However, these numbers might be an under-estimation of the real removal of wood, as a comparison between satellite imagery and forest statistics in Italy has shown (Corona et al., 2007).

\section{Waste sector}

There is little quantitative information on sewage sludge applied to agricultural fields. The value indicated in the figure above has been obtained from the national GHG inventories of European counties to the UNFCCC. In EU15, only seven countries report that domestic or industrial sewage sludge is applied to agricultural soils. The total of $45 \mathrm{Gg} \mathrm{N}$ per year is only a small fraction of the $0.7 \mathrm{Tg} \mathrm{N}$ of sewage sludge that is assumed to enter the solid waste sector. We do not distinguish here landfilling and waste burning.

The input to the waste sector is mainly determined by household wastes; the estimate for the input to the solid waste systems includes currently only agricultural wastes. The IMAGE model uses a nitrogen factor of $3-4 \mathrm{~kg} \mathrm{~N}$ capita ${ }^{-1} \mathrm{yr}^{-1}$, a value which is also confirmed from data which gave a value of $3.94 \mathrm{~kg} \mathrm{~N}$ per capita for over 60 catchments in the UK (Johnes, 2007). The IMAGE data are based on measured nitrogen influent to wastewater treatment plants, divided by the number of connected people. Therefore, the estimate based on human diet may be higher. For example, Billen et al. (2008) estimate an annual food intake of $8.2 \mathrm{~kg} \mathrm{~N}$ capita $^{-1} \mathrm{yr}^{-1}$ from national French domestic consumption data; the estimate based on household consumption figures may be higher. These include products bought but not ingested, the fate of which is solid wastes instead of wastewater. The CAPRI data used here suggest higher values with about $5 \mathrm{Tg} \mathrm{N}$ offered to the consumers. This contains $6 \%$ nitrogen in non-edible products and an assumed $30 \%$ of food wastes. Thus the actual annual nitrogen consumption in Europe including consumption by pets is estimated to be $6.3 \mathrm{~kg} \mathrm{~N}$ capita $^{-1} \mathrm{yr}^{-1}$ in the input of nitrogen from consumer to the waste water treatment systems is estimated to be $3.1 \mathrm{Tq} \mathrm{N} \mathrm{yr}^{-1}$.

\section{Aquatic systems}

We define coastal areas as the shelf regions with a water depth of less than $200 \mathrm{~m}$ (Uher, 2006). This includes most of the shallow Baltic and most of the North Sea, as well as the Adriatic Sea, but excludes most of the Mediterranean Sea such as the Balearic, Ligurian and Tyrrhenian Seas. Also only narrow strips of the Atlantic coast in Spain and Portugal are included.

Budgeting nitrogen fluxes in aquatic systems is one of the most difficult parts of the European Nitrogen Budget.

- We assume that $\mathrm{N}_{\mathrm{r}}$ leached from soils enters the groundwater, however, sub-surface flow does also occur but has not yet been estimated for Europe. 
- Atmospheric $\mathrm{N}_{\mathrm{r}}$ deposition has been estimated on an 'area-fraction' basis. However, $\mathrm{N}_{\mathrm{r}}$ deposition in sealed and non-sealed urban soils will enter the aquatic system either directly or via sewage treatment systems. This has not been accounted for.

- The models predict total $\mathrm{N}_{\mathrm{r}}$ leaching fluxes; their differentiation between nitrate and organic nitrogen from diffuse sources is not possible at the moment.

Voss et al. (2011, Chapter 8, this volume) have made an attempt to quantify the global nitrogen balance in shelf regions. Most of the flux terms are associated with considerable uncertainty. However, burial in sediments and biological nitrogen fixation are both relatively small flux terms; in Europe, biological nitrogen fixation occurs mainly in the Baltic Sea and thus the value shown in the figure above is the estimate reported for the Baltic Sea (Rahm et al., 2000; Schneider et al., 2003). However, the contribution of benthic nitrogen fixation is not considered in this value, as estimates are lacking. Burial in sediments is likely to be a small loss term, which we are not able to quantify for European shelf regions.

\subsection{Conclusion}

Environmental problems related to nitrogen concern all economic sectors and impact all media: atmosphere, pedosphere, hydrosphere and anthroposphere. Therefore, the integration of fluxes presented in depth in earlier chapters for individual sectors/media is needed to get a picture of the overall problem. This chapter presents a set of high resolution maps showing key elements of the $\mathrm{N}$ flux budget across Europe. Additionally, comparative nitrogen budgets are presented for a range of European countries. A European Nitrogen Budget is presented on the basis of state-of-the-art Europe-wide models and databases focusing on different parts of Europe's society.

Key maps of nitrogen fluxes have been plotted from five models and databases covering together all sectors and media in Europe. These models combine a large spatial extent with a high spatial resolution of the data and a focus on nitrogen fluxes. The maps show high pressure on the environment in regions used intensively for agriculture such as the Netherlands, the Po Valley, Brittany, but also in the banlieue of large metropolitan areas such as Paris, Berlin and London. These areas have high $\mathrm{N}$-input and agricultural surplus as well as $\mathrm{NH}_{3}$ and $\mathrm{N}_{2} \mathrm{O}$ fluxes. $\mathrm{NO}_{\mathrm{x}}$ emissions, on the other hand, are dominated by industrial and combustion sources and their distribution reflects the degree of industrialization and population density. The map shows hotspots in centres of energyintensive industry, such as Sachsen-Anhalt in Germany, North Italy, the Netherlands, or along intensive traffic lines. The spatial distribution of $\mathrm{N}_{2} \mathrm{O}$ fluxes shows elements of both patterns, but it is further complicated by the strong dependence of $\mathrm{N}_{2} \mathrm{O}$ emissions from soil properties and meteorological conditions. Land productivity in Europe is high and could be sufficient to sustain the protein requirement of European population. However, a large part of these resources is invested to feed the livestock, which consume three times the nitrogen that humans consume but deliver only about $50 \%$ of the proteins in human's diet in EU-27. As a consequence, large amount of feedstuff must be imported to Europe.

National nitrogen budgets are difficult to compile using a wide range of data sources and are currently available only for a limited number of countries. The summary of the national $\mathrm{N}$-budgets shows that the balance is not closed for several sectors. This is partly because not all nitrogen fluxes have yet been (or could be) estimated, and partly because the data for different compartments and sectors have been taken from best available, but partly inconsistent, data sets. Overall, national $\mathrm{N}$-budgets have already shown themselves to be useful tools to identify the most important $\mathrm{N}$-fluxes in a country, to provide an efficient visualization of the complexity of a problem and to elaborate efficient mitigation strategies. Furthermore, through the integration of data from different and independent sources, data gaps and sometimes contradicting scientific understanding of processes have been highlighted.

Modelling approaches have been used to fill in the data gaps in some of these budgets, but it became obvious during this study that further research is needed in order to collect necessary data and make national nitrogen budgets inter-comparable across Europe. The European Nitrogen Budget is largely modelbased and provided a challenge in combining five Europe-wide models and databases. Results suggest that European agriculture (EU-27) receives $c .18 \mathrm{Tg} \mathrm{N} \mathrm{yr}^{-1}$ reactive nitrogen, out of which only $c .7 \mathrm{Tg} \mathrm{N} \mathrm{yr}^{-1}$ find their way to the consumer or are

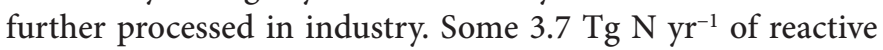
nitrogen are released by the burning of fossil fuel, out of about $16 \mathrm{Tg} \mathrm{N} \mathrm{yr}^{-1}$ of $\mathrm{N}_{2}$ which is fixed into $\mathrm{N}_{\mathrm{r}}$ each year in industry and energy generation. The contribution in emissions of reactive nitrogen of the industry and energy sectors is comparable to that of the transport sector.

More than $8 \mathrm{Tg} \mathrm{N} \mathrm{yr}^{-1}$ of reactive nitrogen are disposed of to the hydrosphere; Europe is a net exporter of $\mathrm{N}_{\mathrm{r}}$ through atmospheric transport of $c .2 .3 \mathrm{Tg} \mathrm{N} \mathrm{yr}{ }^{-1}$. The largest single sink for $\mathrm{N}_{\mathrm{r}}$ appears to be denitrification to $\mathrm{N}_{2}$ in European shelf regions. However, this sink is also the most uncertain one as it concerns also $\mathrm{N}_{\mathrm{r}}$ that is imported through the exchange with the open ocean which is potentially as large as the input of $\mathrm{N}_{\mathrm{r}}$ in mineral fertilizer.

In contrast to most chapters in this assessment, the current chapter presents considerable new information that has been just lately compiled, estimated or calculated with recently improved models. The European Nitrogen Assessment aims at providing a comprehensive assessment of nitrogen, its related problems and possible solutions, but also at raising awareness on nitrogen issues and promoting the idea of integrated assessment as an important prerequisite for successful solutions. The large variety of problems associated with the excess of reactive nitrogen in the European environment requires such an integrated nitrogen management approach that would allow for creation and closure of $\mathrm{N}$ budgets within European environments.

The first steps to reach this goal have already been taken in the process of assembling the assessment, jointly with the 
contemporarily formed Task Force on Reactive Nitrogen under the UN-CLRTAP and the NitroEurope-Integrated Project. The progress of this joint effort is reflected in this chapter.

\section{Acknowledgements}

The authors gratefully acknowledge support from the European Commission for the NitroEurope Integrated Project, and from the European Science Foundation for the Nitrogen in Europe (NinE) programme and COST 729.

\section{Supplementary materials}

Supplementary materials (as referenced in the chapter) are available online through both Cambridge University Press: www.cambridge.org/ena and the Nitrogen in Europe website: www.nine-esf.org/ena .

\section{References}

Aber, J. D. (1992). Nitrogen cycling and nitrogen saturation in temperate forest ecosystems. Trends Ecol., Evol., 7, 220-224.

ACEA (2009). Historical series 1990 - 2008, average car age in Europe, publications 2009, European Automobile Manufacturers Association. Available at http://www.acea.be/index.php/collection/ statistics.

Amann, M., Asman, W., Bertok, I. et al. (2007). Cost-effective emission reductions to meet the Environmental Targets of the Thematic Strategy on Air Pollution under different greenhouse gas constraints NEC, Scenario Analysis Report Nr. 5. IIASA, June 2007.

Andersson-Sköld, Y. and Simpson, D. (1999). Comparison of the chemical schemes of the EMEP MSC-W and the IVL photochemical trajectory models. Atmos. Env., 33, 1111-1129.

BAFU 2010: Sticksloffflüsse in der Schweiz, Stoffflussanalyse für das Jahr 2005, Heldstab J., Reusimann J., Bledermann R., Len D. Im Auftrag des Bundesamis für ummett BAFU, limwett Hissen Nr. 1018. Bern.

Bange, H. W. (2008). Gaseous nitrogen compounds (NO, $\mathrm{N}_{2} \mathrm{O}, \mathrm{N}_{2}$, $\mathrm{NH}_{3}$ ) in the ocean. In: Nitrogen in the Marine Environment, 2nd edition. Capone, D. G., Bronk, D. A., Mulholland, M. R. and Carpenter, E. J. (eds.), Elsevier, Amsterdam, pp. 51-94.

Billen, G., Garnier, J., Mouchel, J.-M. and Silvestre, M. (2007). The Seine System: introduction to a multidisciplinary approach of the functioning of a regional river system. Sci. Total Environ., 375, $1-12$.

Billen, G., Barles, S., Garnier, J., Rouillard, J. and Benoit, P. (2008). The food-print of Paris: long-term reconstruction of the nitrogen flows imported into the city from its rural hinterland. Region. Environ.Change, http://dx.doi.org/10.1007/ s10113-008-0051-y

Billen, G., Silvestre, M., Grizzetti, B. et al. (2011). Nitrogen flows from European watersheds to coastal marine waters. In: The European Nitrogen Assessment, ed. M. A. Sutton, C. M. Howard, J. W. Erisman et al., Cambridge University Press.

Bouwman, A. F., Kram, T. and Klein Goldewijk, K. (2006). Integrated modelling of global environmental change: an overview of IMAGE 2.4, Netherlands Environmental Assessment Agency (MNP): Bilthoven, The Netherlands.
Britz, W. and Leip, A. (2009). Development of marginal emission factors for $\mathrm{N}$ losses from agricultural soils with the DNDC-CAPRI meta-model. Agric. Ecosyst. Environ., 133, 267-279.

Britz, W. and Witzke, H.-P. (eds.) (2008). CAPRI Model Documentation 2008: Version 2 p. Institute for Food and Resource Economics, University of Bonn: Bonn (available at http://www. capri-model.org/docs/capri_documentation.pdf)

Butterbach-Bahl, K., Kahl, M., Mykhayliv, L. et al. (2008). A European wide inventory of soil NO emissions using the biogeochemical models DNDC/ Forest DNDC . Atmos. Environ., 43, 1392-1402.

Butterbach-Bahl, K., Gundersen, P., Ambus, P. et al. (2011). Nitrogen processes in terrestrial ecosystems. In: The European Nitrogen Assessment, ed. M. A. Sutton, C. M. Howard, J. W. Erisman, et al., Cambridge University Press.

BUWAL (1996). Strategie zur Reduktion der Stickstoffemissionen. Bericht der Projektgruppe Stickstoffhaushalt Schweiz, Schriftenreihe Umwelt Nr. 273, Bundesamt für Umwelt, Wald und Landschaft (BUWAL) and Bundesamt für Landwirtschaft (BLW): Bern, Switzerland.

CDIAC (2008). Fossil-fuel $\mathrm{CO}_{2}$ emissions. http://cdiac.ornl.gov/ trends/emis/meth_reg.html. Last accessed on 11.08.2009.

Cofala, J., Amann, M., Klimont, Z., Kupiainen, K. and HöglundIsaksson, L. (2007). Scenarios of global anthropogenic emissions of air pollutants and methane until 2030. Atmos. Environ., 41, 8486-8499.

CONCAWE (1997). Motor vehicle emission regulations and fuel specification - part 2, detailed information and historic reviews (1970 - 1996), report 6/1997.

CONCAWE (2001). Motor Vehicle emission regulations and fuel specification - part 2, detailed information and historic reviews (1996 - 2000), report 2/2001.

Corona, P., Giuliarelli, D., Lamonaca, A. et al. (2007). Confronto sperimentale tra superfici a ceduo tagliate a raso osservate mediante immagini satellitari ad alta risoluzione e tagliate riscontrate amministrativamente. Forest, 4, 324-332.

Dalsøren, S. B., Eide, M. S., Endresen, Ø. et al. (2009). Update on emissions and environmental impacts from the international fleet of ships. The contribution from major ship types and ports. Atmos. Chem. Phys., 9, 2171-2194.

De Vries W., Kros, J., Reinds, G. J. et al. (2009). INTEGRATOR: a modelling tool for European-wide assessments of nitrogen and greenhouse gas fluxes in response to changes in land cover, land management and climate - calculation procedures, application methodology and examples of scenario results, Alterra Report, Alterra Wageningen UR: Wageningen, The Netherlands.

de Vries, W., Leip, A., Reinds, G. J. et al. (2011). Geographic variation in terrestrial nitrogen budgets across Europe. In: The European Nitrogen Assessment, ed. M. A. Sutton, C. M. Howard, J. W. Erisman et al., Cambridge University Press.

DEFRA (2008). Summary of Food and Farming in the UK, HMSO: London.

Domene, L. A. F. and Robert, U. A. (2001). Nitrogen's role in industrial systems. J. Industr. Ecol., 5, 77-103.

ECN (2008). European Compost Network: Webpages EU Biowaste Treatment and Country presentations. http://www. compostnetwork.info/. Last accessed on 11.08.2009.

EEA (1998). Annual topic update 1997. Topic report 02/98, European Environment Agency and European Topic Centre on Coastal and Marine Environment: Copenhagen. 
EEA (2009a). NEC Directive status report 2008, Reporting by the Member States under Directive 2001/81/EC of the European Parliament and of the Council of 23 October 2001 on national emission ceilings for certain atmospheric pollutants EEA Technical report series: European Environment Agency: Copenhagen.

EEA (2009b). Annual European Community greenhouse gas inventory 1990-2007 and inventory report 2009, submission to the UNFCCC Secretariat, European Environment Agency: Copenhagen.

EEA (2010). Annual European Community greenhouse gas inventory 1990-2008 and inventory report 2010, submission to the UNFCCC secretariat, European Environment Agency: Copenhagen.

EIA (2007). International energy statistics. U.S. Energy Information Administration: Washington DC, USA. http://www.eia.doe.gov/ emeu/international/contents.html. Last accessed on 2007.

EMEP (2008). EMEP measurement database. The Co-operative Programme for the Monitoring and Evaluation of the Long-Range Transmission of Air Pollutants in Europe. Available at http://www. emep.int/.

EMEP/EEA (2009). EMEP/EEA air pollutant emission inventory guidebook: 2009, EEA Technical Report. Available at http:// www.eea.europa.eu/publications/emep-eea-emission-inventoryguidebook-2009.

Erisman, J. W., Domburg, P., de Haan, B. J. et al. (2005). The Dutch nitrogen cascade in the European perspective, ECN-C - 05-007, Energy Research Centre of the Netherlands (ECN): Petten, The Netherlands.

Erisman, J. W., Sutton, M. A., Galloway, J., Klimont, Z. and Winiwarter, W. (2008). How a century of ammonia synthesis changed the world. Nature Geosci., 1, 636-639.

Eyers, C. J., Addleton, D., Atkinson, K. et al. (2004). AERO2k Global Aviation Emissions Inventories for 2002 and 2025, QINETIQ/04/01113, December 2004. Available at http://www. cate.mmu.ac.uk/aero2kreports/AERO_2k_Global_Aviation_ Emissions_Inventories_for_2002_and_2025_V1_1.pdf.

Galloway, J. N. and Cowling E. B. (2002). Reactive nitrogen and the world: 200 years of change. Ambio, 31, 64-71.

Galloway J. N., Cowling E. B. and Kessler E. (2002). Reactive nitrogen. Ambio 31, 59.

Galloway, J. N., Aber, J. D., Erisman, J. W. et al. (2003). The Nitrogen Cascade. BioScience, 53, 341-356.

Galloway, J. N., Townsend, A. R., Erisman, J. W. et al. (2008). Transformation of the nitrogen cycle: recent trends, questions, and potential solutions. Science, 320, 889-892.

Genovese, G., Baruth, B., Royer, A. and Burger, A. (2007). Crop and yield monitoring activities: MARS STAT action of the European Commission. Geoinformatics, 10, 20-22.

Heckelei, T., Mittelhammer, R. C. and Britz, W. (2005). A Bayesian alternative to generalized cross entropy solutions to underdetermined models. In: 89th EAAE Symposium Modelling Agricultural Policies: State of the Art and New Challanges, 3-5 February, Parma, Italy.

Hertel, O., Reis, S., Skjøth, C. A. et al. (2011). Nitrogen turnover processes in the atmosphere. In: The European Nitrogen Assessment, ed. M. A. Sutton, C. M. Howard, J. W. Erismon et al., Cambridge University Press.

IEA/OECD (2007). Energy balances of OECD and non-OECD countries on-line data service, $20037 \mathrm{http}$ ///data.iea.org.

IFA (2010). Global Fertilizers and Raw Materials Supply and Supply/ Demand Balances, 2010-2014. Prud'homme, M., June 2010.
IPCC (2006). 2006 IPCC guidelines for national greenhouse gas inventories, prepared by the National Greenhouse Gas Inventories Programme, IGES: Tokyo, Japan.

IPCC (2007). Fourth Assessment Report of the Intergovernmental Panel on Climate Change. Working Group I - The Physical Science Basis. Summary for policymakers. Available at http://www.ipcc.ch/ WG1_SPM_17Apr07.pdf.

IRF (2007). World Road Statistics 2007.

Jeppsson, U., Alex, J., Pons, M. N., Spanjers, H. and Vanrolleghem, P. A. (2002). Status and future trends of ICA in waste water treatment- a European perspective. Water Sci. Technol., 45, 485-494.

Johnes, P. D. (1996). Evaluation and management of the impact of land use change on the nitrogen and phosphorus load delivered to surface waters: the export coefficient modelling approach. J. Hydrol., 183, 323-349.

Johnes, P. J. (2007). Meeting ecological restoration targets in European waters: a challenge for animal agriculture. In: Redesigning Animal Agriculture, ed. D. Swain, E. Charmley, J. Steel and S. Coffey, CAB International: Wallingford, UK, pp. 185-203.

Johnes, P. J. and Butterfield, D. (2002). Landscape, regional and global estimates of $\mathrm{N}$ flux from land to ocean: errors and uncertainties. Biogeochemistry, 57/58, 429-476.

JRC/PBL (2009). The EDGAR database EDGAR v4.0, available at http:\ledgar.jrc.ec.europa.eu\

Katri, K., Seija, K., Pekka, S. et al. (2004). Effect of elevated $\left[\mathrm{CO}_{2}\right]$ on stem wood properties of mature Norway spruce grown at different soil nutrient availability. Glob. Change Biol., 10, 1526-1538.

Kesik, M., Ambus, P., Baritz, R. et al. (2005). Inventory of $\mathrm{N}_{2} \mathrm{O}$ and $\mathrm{NO}$ emissions from European forest soils. Biogeosciences, 2, 353-357.

Klimont, Z. and Brink, C. (2004). Modelling of emissions of air pollutants and greenhouse gases from agricultural sources in Europe, IIASA Interim Report IR-04-048, International Institute for Applied Systems Analysis: Laxenburg, Austria.

Lambrecht, M., Erdmenger, C., Bölke, M. et al. (2009). Strategie für einen nachhaltigen Güterverkehr (Summary: Strategy for Sustainable Freight Transport in English), UBA Texte 18/2009.

Leip, A., Marchi, G., Koeble, R. et al. (2008). Linking an economic model for European agriculture with a mechanistic model to estimate nitrogen and carbon losses from arable soils in Europe. Biogeosciences, 5, 73-94.

Leip, A., Weiss, F. and Britz, W. (2009a). Agri-environmental nitrogen indicators for EU27. In: Proceedings of the Conference on Integrated Assessment of Agriculture and Sustainable Development: Setting the Agenda for Science and Policy (AgSAP 2009). Egmond aan Zee, The Netherlands, 10-12 March 2009, ed. M. K. Van Ittersum, J. Wolf and H. H. Van Laar, Wageningen University and Research Centre: Wageningen, the Netherlands, pp. 184-185.

Leip, A., Weiss, F., Orlandini, L. and Marchi, G. (2009b). Nitrous oxide emissions from agriculture in Europe as calculated within the Indicator Database for European Agriculture. In: Fifth International Symposium on Non-CO2 Greenhouse Gases (NCGG-5) Science, Reduction Policy and Implementation, Wageningen, the Netherlands, 30 June - 3 July, 2009.

Leip A., Britz W., de Vries W. and Weiss F. (2011). Farm, land, and soil nitrogen budgets for agriculture in Europe. Environ. Pollu. (in press).

Leip, A., Busto, M. and Winiwarter, W. (2010b). Developing stratified $\mathrm{N}_{2} \mathrm{O}$ emission factors for Europe. Environ. Pollut. (in press). 
Li, C. (2000). Modeling trace gas emissions from agricultural ecosystems. Nutr. Cycl. Agroecosyst., 58, 259-276.

Metzger, S. M., Dentener, F. J., Lelieveld, J. and Pandis, S. N. (2002). Gas/aerosol partitioning 1. A computionally efficient model. J. Geophys. Res., 107 (ACH16).

NitroEurope (2010) http://www.nitroeurope.eu/ (accessed 1 June 2010).

OECD/Eurostat (2003). OECD/Eurostat gross nitrogen balances handbook. Organisation for Economic Co-operation and Development, Paris.

Olivier, J. G. J., van Aardenne, J., Dentener, F. et al. (2005). Recent trends in global greenhouse gas emissions: regional trends 1970-2000 and spatial distribution of key sources in 2000. Environ. Sci., 2, 81-99.

Pilegaard, K., Skiba, U., Ambus, P. et al. (2006). Factors controlling regional differences in forest soil emission of nitrogen oxides (NO and $\mathrm{N}_{2} \mathrm{O}$ ). Biogeosciences, 3, 651-661.

Prud ' homme, M. (2009). IFA Production and International Trade Committee, personal communication.

Pulles, T., van het Bolscher, M., Brandt, R. and Visschedijk, A. (2007). Assessment of global emissions from fuel combustions in the final decades of the 20th century DG Research, Retro Project, No. 034.64145, TNO report, 2007-A-R0132/B. p. 41.

Rahm, L. et al. (2000). Nitrogen fixation in the Baltic proper: an empirical study. J. Mar. Sys., 25, 239-248.

Schneider, B. et al. (2003). The surface water $\mathrm{CO}_{2}$ budget for the Baltic Proper: a new way to determine nitrogen fixation. J. Mar. Syst., 42, 53-64.

Seitzinger, S., Harrison, J. A., Böhlke, J. K. et al. (2006). Denitrification across landscapes and waterscapes: a synthesis. Ecol. Appl., 16, 2064-2090.

Simpson, D., Winiwarter, W., Börjesson, G. et al. (1999). Inventorying emissions from nature in Europe. J. Geophys. Res., D104, 8113-8152.

Simpson, D., Fagerli, H., Jonson, J. et al. (2003). The EMEP unified Eulerian model. model description, EMEP Report 1/2003, The Norwegian Meteorological Institute, Oslo, Norway.

Simpson, D., Butterbach-Bahl, K., Fagerli H. et al. (2006). Deposition and emissions of reactive nitrogen over European forests: a modelling study. Atmos. Environ., 40, 5712-5726.

Simpson, D., Aas, W., Bartnicki, J. et al. (2011). Atmospheric transport and deposition of nitrogen in Europe. In: The European Nitrogen Assessment, ed. M. A. Sutton, C. M. Howard, J. W. Erisman et al., Cambridge University Press.

SRIC (2005). Adipic acid, nitric acid and caprolactam production data 1974-2004, Tables from the Directory of Chemical Producers, dated 2 December 2005. SRI Consulting, Gaithersburg, MD.

Stoddard, J. L. (1994). Long-term changes in watershed retention of nitrogen: its causes and aquatic consequences. In: Environmental Chemistry of Lakes and Reservoirs, ed. L. A. Baker. Washington (DC): American Chemical Society, pp. 223-284.

Streets, D. G. and Waldhoff, S. T. (2000). Present and future emissions of air pollutants in China: $\mathrm{SO}_{2}, \mathrm{NO}_{\mathrm{x}}$, and CO. Atmos. Environ., 34, 363-374.

Sutton, M. A., Nemitz, E., Erisman, J. W. et al. (2007). Challenges in quantifying biosphere-atmosphere exchange of nitrogen species. Environ. Pollu., 150, 125-139.
Sutton, M. A., Howard, C. M., Erisman J. W. et al. (2011). Assessing our nitrogen inheritance. In: The European Nitrogen Assessment, ed. M. A. Sutton, C. M. Howard, J. W. Erisman et al., Cambridge University Press.

Svirejeva-Hopkins, A., Reis, S., Nardoto G. et al. (2011). Nitrogen flows and fate in urban landscapes. In: The European Nitrogen Assessment, ed. M. A., Sutton, C. M. Howard, J. W. Erisman et al. Cambridge University Press.

Uher, G. (2006). Distribution and air-sea exchange of reduced sulphur gases in European coastal waters. Estuar. Coast. Shelf Sci., 70, 338-360.

Umweltbundesamt (2009a). Integrierte Strategie zur Minderung von Stickstoffemissionen, Umweltbundesamt. Available at http://www.umweltbundesamt.de/luft/downloads/emissionen/ stickstoffemissionsminderungsstrategie.pdf, last accessed on 26.11.2008.

Umweltbundesamt (2009b). Hintergrundpapier zu einer multimedialen Stickstoffemissionsminderungsstrategie, Umweltbundesamt. Available at http://www. umweltbundesamt.de/luft/downloads/emissionen/ hg-stickstoffemissionsminderungsstrategie.pdf, last accessed on 26.11.2008.

UNEP and WHRC (2007). Reactive nitrogen in the environment: too much or too little of a good thing: United Nations Environment Programme: Paris.

Van Aardenne, J. A., Dentener, F. J., Olivier, J. G. J., Klein Goldewijk, C. G. M. and Lelieveld, J. (2001). A high resolution dataset of historical anthropogenic trace gas emissions for the period 1890-1990. Glob. Biogeochem. Cycles, 15, 909-928.

Van Aardenne, J., Doering, U., Monni, S. et al. (2009). Emission Inventory for period 1990-2005 on 0.1x0.1 grid. Report to the Sixth Framework Programme Project No. 036961-CIRCE, 23 January 2009.

Van der Werft, G. et al. (2010). http://www.falw.vu/ gwerf/GFED/ index.html (site accessed 1 June 2010).

Van Drecht, G., Bouwman, A. F., Harrison, J. and Knoop, J. M. (2009). Global nitrogen and phosphate in urban wastewater, between 1970 and 2050. Glob. Biogeochem. Cycles, $23\left(\mathrm{~GB}_{0} \mathrm{~A} 03\right)$.

van Egmond, K., Bresser, T. and Bouwman, L. (2002). The European Nitrogen Case. Ambio, 31, 72-78.

van Grinsven, J. J. M., van Schijndel, M. W., Schotten, C. G. J. and van Zeijts, H. (2003). Integrale analyse van stikstofstromen en stikstof beleid in Nederland, RIVM report 500003001, RIVM, Bilthoven, The Netherlands.

Velthof, G., Oudendaag, D., Witzke, H.-P. et al. (2009). Integrated assessment of nitrogen emissions from agriculture in EU-27 using MITERRA-EUROPE. J. Environ. Qual., 38, 402-417.

Vestreng, V., Ntziachristos, L., Semb, A. et al. (2009). Evolution of $\mathrm{NO}_{\mathrm{x}}$ emissions in Europe with focus on road transport control measures. Atmos. Chem. Phys., 9, 1503-1520.

Voss, M., Baker, A. Bange, H. W. (2011). Nitrogen processes in coastal and marine systems. In: The European Nitrogen Assessment, ed. M. A. Sutton, C. M. Howard, J. W. Erisman et al., Cambridge University Press.

Wang, C., Corbett, J. J. and Firestone, J. (2007). Improving spatial representation of global ship emissions inventories. Environ. Sci. Technol., 42, 193-199.

Weigelt, A., Weisser, W. W., Buchmann, N. and Scherer-Lorenzen, M. (2009). Biodiversity for multifunctional grasslands: equal 
productivity in high-diversity low-input and low-diversity highinput systems. Biogeosciences, 6, 1695-1706.

Weiss, F., Leip, A., 2010. Methodology for quantification of greenhouse gas and ammonia emissions from the livestock sector in EU27. In: Leip, A., Weiss, F., Wassenaar, T., Pexz, I., Fullmann, T., Londjani, P., Tubiesso, F., Grandgirand, D., Monni, S., Bicüa, K. (eds.) Evaluation of the livestock sector's contribution to the EU greenhouse gas emissions (GGELS) - final report. European Commission, Joint Research Centre.
Wieland, U. (2003). Water use and waste water treatment in the EU and in candidate countries. Statistics in Focus, Theme 8-13/2003, Eurostat.

Winiwarter, W., Hettelingh, J. P., Bouwman, L. et al. (2011). Future scenarios of nitrogen in Europe. In: The European Nitrogen Assessment, ed. M. A. Sutton, C. M. Howard, J. W. Erisman et al., Cambridge University Press. 